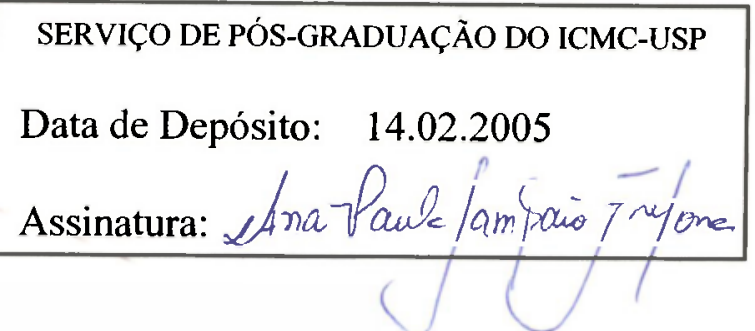

\title{
SciaGeo - Um sistema de captura de imagens aéreas georeferenciadas
}

\author{
Luís Fernando Curci Chavier
}

Orientador: Prof. Dr. Onofre Trindade Júnior

Dissertação apresentada ao Instituto de Ciências Matemáticas e de Computação - ICMC-USP, como parte dos requisitos para obtenção do título de Mestre em Ciências de Computação e Matemática Computacional. 
Aluno: Luis Fernando Curci Chavier

A Comissão Julgadora:

Prof. Dr. Onofre Trindade Junior

Prof. Dr. Luis Gustavo Nonato

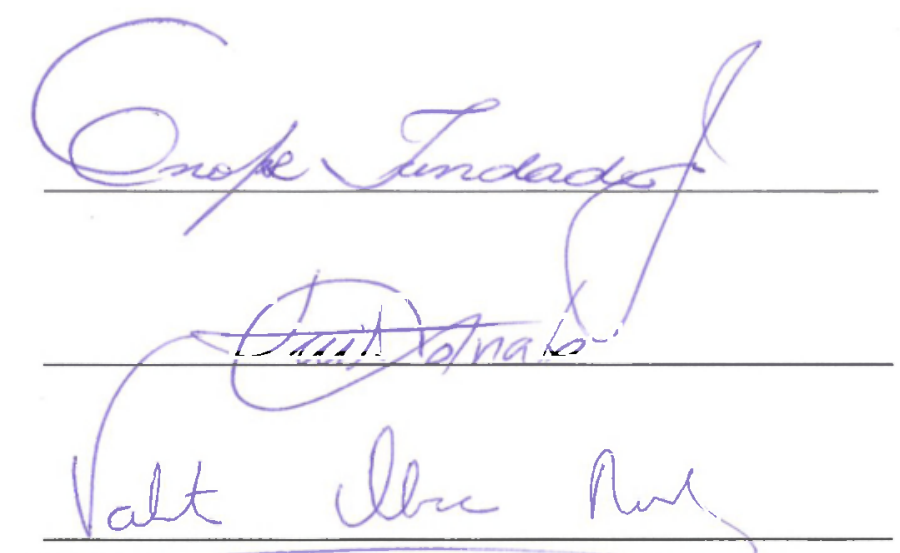

Prof. Dr. Valentin Obac Roda 
A Deus,

à minha esposa Danielle c aos meus pais Dalila e Chavier. 


\section{Agradecimentos}

Primeiramente agradeço à minha esposa, aos meus pais e às minhas tias Lia e Jurema pclo incentivo no desenvolvimento deste trabalho.

Ao meu orientador, Prof. Onofre Trindade Júnior, pela orientação, apoio, e por todo o conhecinento que me transmitiu neste período.

Ao pesquisador Lúcio André de Castro Jorge, pelo processamento das imagens, extremamente importante para a conclusão e validação do trabalho.

Ao colega Luciano de Oliveira Neris, pela grande ajuda técnica no desenvolvimento deste trabalho.

À Fazenda Campo Bom, por ceder as áreas de teste e pelo apoio na realização do imageamento.

A todos os funcionários do ICMC e a todos aqueles que, de uma forma ou de outra, contribuíram para a realização deste trabalho. 


\section{Sumário}

1 Introdução 1

1.1 Organização do Texto $\ldots \ldots \ldots \ldots \ldots \ldots \ldots \ldots \ldots \ldots$

2 Contexto 4

2.1 Sistemas de Informação Geográfica $\ldots \ldots \ldots \ldots \ldots \ldots$

2.1 .1 Componentes de 1 SIG $\ldots \ldots \ldots \ldots \ldots$

2.1 .2 Aplicaçôs de SIGs . . . . . . . . . . . . . . . . 7

2.2 Dispositivos de Captura de Irnagens $\ldots \ldots \ldots \ldots \ldots \ldots$

2.2 .1 Câmeras Fotográficas $\ldots \ldots \ldots \ldots \ldots \ldots \ldots$

2.2 .2 Câmeras Fotográficas Digitais . . . . . . . . . . . . . . . . 14

2.2 .3 Câmeras Filmadoras . . . . . . . . . . . . . . . . . . . 16

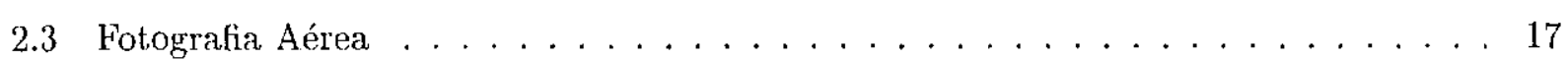

2.3 .1 Acrofotogrametria . . . . . . . . . . . . . . . 17

2.3.2 Fotografia Aérea Digital e de Pequcno Formato . . . . . . . . . . . . 21

2.3 .3 Fotografia Aćrea com Acronaves do Tipo Ultraleve . . . . . . . . . . . 23

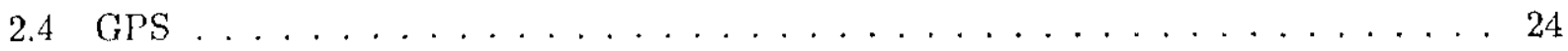

2.4 .1 Princípio de Funcionamento do GPS . . . . . . . . . . . 24

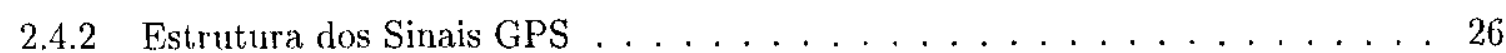

2.4 .3 Segmentos do Navstar-GPS . . . . . . . . . . . . . . . . . . . 28

2.4.4 Interface com Reccptores GPS . . . . . . . . . . . . . . 30

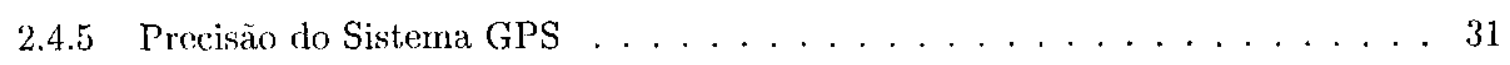

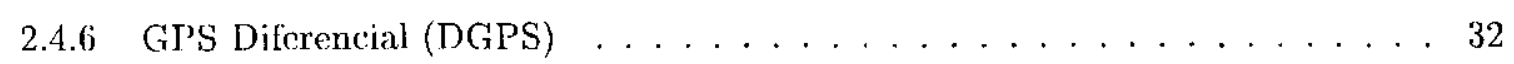

2.5 Georeferenciamento de Imagens Aćrcas . . . . . . . . . . . . . . . . . . 34

2.5 .1 Georeferenciamento Indireto . . . . . . . . . . . . . . . . . . . 34

2.5 .2 Georefcrenciamento Direto . . . . . . . . . . . . . . 35 
2.5.3 Amostragem Aérea Pontual . . . . . . . . . . . . . . 36

2.6 Consideraçôes Finais . . . . . . . . . . . . . . . . . . . 37

3 Análise de Requisitos e Especificação do SciaGeo 38

3.1 Introdução . . . . . . . . . . . . . . . . . . . 38

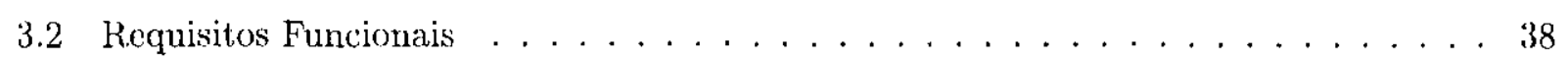

3.3 Requisitos Não Funcionais . . . . . . . . . . . . . . . . . 39

3.4 Diagramas de Blocos . . . . . . . . . . . . . . . . . 40

3.5 Diagrama de Fluxo de Dados - DFD . . . . . . . . . . . . . . 43

3.6 Considerações Finais . . . . . . . . . . . . . . . . . . . 44

4 Projeto e Implementação - Hardware $\quad 45$

4.1 Introdução . . . . . . . . . . . . . . . . . . . . . 45

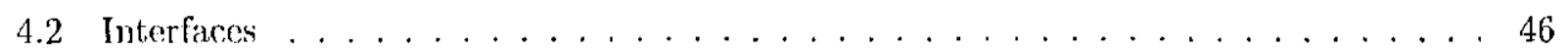

4.3 Seleção de Dispositivos para Implementação $\ldots \ldots$. . . . . . . . . . . . . . 47

4.3 .1 Processador Principal . . . . . . . . . . . . . . . 47

4.3 .2 Câmera Fotográfica . . . . . . . . . . . . . . . 48

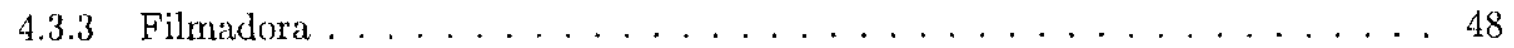

4.3 .4 Receptor GPS . . . . . . . . . . . . . . . 49

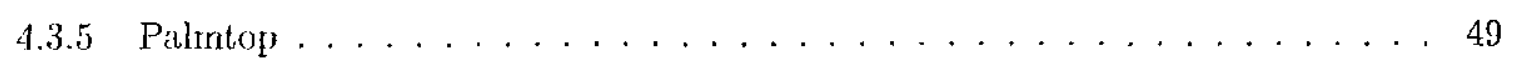

4.4 Descrição Detalhada do Hardware Desenvolvido . . . . . . . . . . . . . . . 50

4.4 Módulo Controlador de Câmera . . . . . . . . . . . . . . . . 50

4.4 .2 Conversor de Níveis Lógicos RS232/TTL . . . . . . . . . . . . . . 51

4.4 .3 Fonte de Alimentação . . . . . . . . . . . . . . . . 51

4.4 .4 Modem de $2400 \mathrm{bps} \ldots \ldots \ldots \ldots \ldots \ldots$

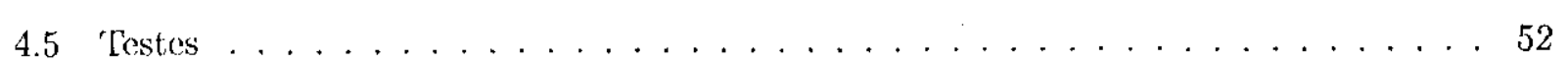

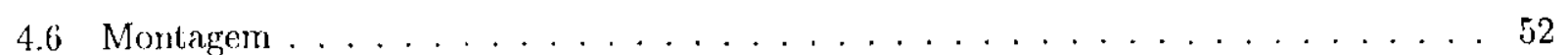

4.7 Considerações Finais . . . . . . . . . . . . . . . . . . . 53

5 Projeto e Implementação -- Software 55

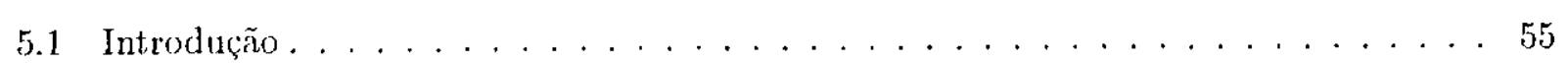

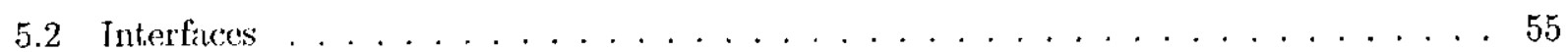

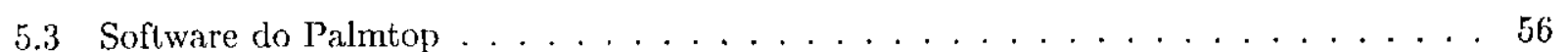

5.4 Software do Processador Principal . . . . . . . . . . . . . . . 57 
5.5 Software do Controlador de Câmera . . . . . . . . . . . . . . . 58

5.6 Software de Extração de Coordenadas c Quadros de Vídeo . . . . . . . . . . . . . . . 59

5.7 Ambiente de Implementação . . . . . . . . . . . . . . . . . . . . 60

5.7 .1 Processador Principal . . . . . . . . . . . . . . 60

5.7 .2 Controlador de Câmera . . . . . . . . . . . . . . . . 61

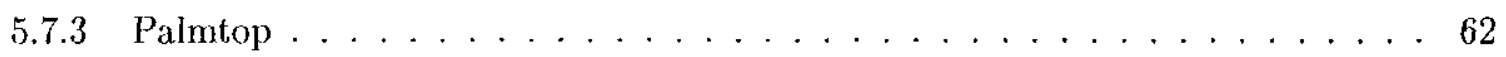

5.7 .4 Software de Extração de Imagens e Coordenadas . . . . . . . . . . . . . 62

5.8 Testes Modulares e de Integração . . . . . . . . . . . . . . . . . . . . . . 62

5.9 Considerações Finais . . . . . . . . . . . . . . . . . . . . 62

6 Instalação e Operação do SciaGeo $\quad 63$

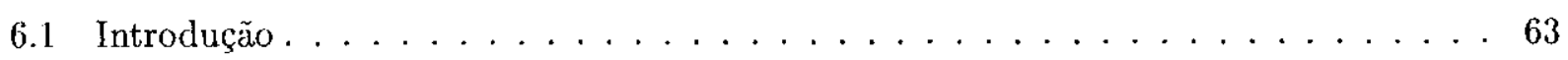

6.2 Instalação do Equipamento . . . . . . . . . . . . . . 63

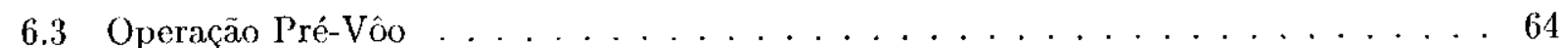

6.4 Operação Durante o Vôo . . . . . . . . . . . . . . . . . 64

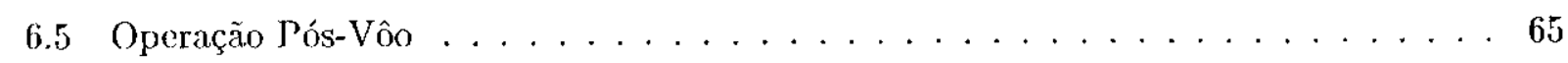

6.6 Consideraçōes Finais . . . . . . . . . . . . . . . . . . . 66

$\begin{array}{llr}7 & \text { Resultados } & 67\end{array}$

7.1 Introdução . . . . . . . . . . . . . . . . . . 67

7.2 A Missão na Fazenda Campo Bom . . . . . . . . . . . . . . . . 67

7.3 Instalação do Equipamento f . . . . . . . . . . . . . . . 68

7.3.1 Câmeras, Lente e Filme Utilizados . . . . . . . . . . . . . . . . . 68

7.3 .2 Fixação do Equipamento na Aeronave . . . . . . . . . . . . . . 68

7.4 Área Monitorada . . . . . . . . . . . . . . . . . . 69

7.5 Operação do SciaGeo . . . . . . . . . . . . . . . . . 69

7.6 Dados Resultantes da Missão . . . . . . . . . . . . . . . . 70

7.6 .1 Análise Visual das Imagens . . . . . . . . . . . . . 73

7.6 .2 Processamento Computacional das Imagens $\ldots \ldots \ldots$

7.6 .3 Integração dos Dados em um SIG . . . . . . . . . . . . . . . 79

7.7 Considerações Finais . . . . . . . . . . . . . . . . . . . 80

8 Conclusões $r$

8.1 Introdução. . . . . . . . . . . . . . . . . . 81 


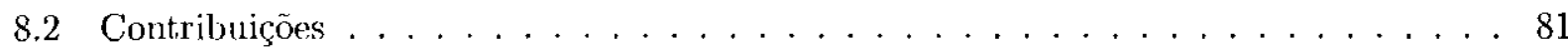

8.3 Dificuldades Encontradas . . . . . . . . . . . . . . . 82

8.4 Trabalhos Futuros . . . . . . . . . . . . . . . . . . 82

8.4 .1 Plancjamento de Missões . . . . . . . . . . . . . . 83

8.4 .2 Auxílio à Navegação . . . . . . . . . . . . . . . 83

8.4 .3 Disparo Automático de Fotografias . . . . . . . . . . . . . 83

8.4 .4 Outros Trabahos . . . . . . . . . . . . . . . 84

$\begin{array}{lr}\text { A Diagramas Esquemáticos } & 89\end{array}$

B Protocolos de Comunicação 192

B.1 Pacole de Dados de Posicionamento . . . . . . . . . . . . . . . . 92

B.1.1 Pacote de Disparo de Fotografia . . . . . . . . . . . . . . . 93

B.1.2 Pacote de Controle da Filmadora . . . . . . . . . . . . . 93

B.1.3 Pacote de Confirmação de Disparo de Fotografia . . . . . . . . . . . . 94

B.1.4 Pacote de Confirmação de Controle da Filmadora . . . . . . . . . . . . . . . 94

$\begin{array}{lr}\text { C Formato do Arquivo de Coordenadas } & 95\end{array}$ 


\section{Lista de Figuras}

2.1 Estrutura geral de um Sistema de Informações Geográficas [CAM 96]. . . . . . . . 6

2.2 Principais componentes de uma câmera fotográfica (adaptado de [HED 79]) . . . . . 9

2.3 Formação de imagens por uma lente de nma câmera [JAC 88]. . . . . . . . . . . . 11

2.4 Ângulo de visão $[$ JAC 88] . . . . . . . . . . . . . . . . . . . . . . 12

2.5 Diafragma em forma de íris $[$ HED 79$] \ldots \ldots \ldots \ldots \ldots \ldots$

2.6 Tipos de obturador de uma câmera fotográfica [HED 79]. . . . . . . . . . . . . 13

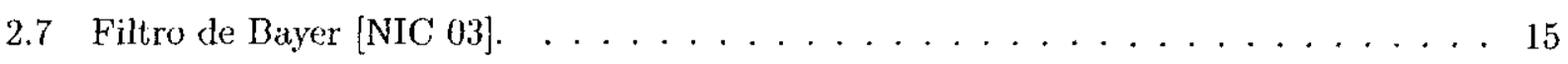

2.8 Tipos de fotografias aéreas segundo o eixo ótico da câmera (adaptado de [MAR 90]). 19

2.9 Projeçōes central e ortográfica. . . . . . . . . . . . . . . . . . . 20

2.10 Como variações no relevo podem afetar a escala em uma fotografia [WAR 96]. . . . 21

2.11 Princípio básico de operação do GPS (adaptado de [LOG 92]) . . . . . . . . . . 25

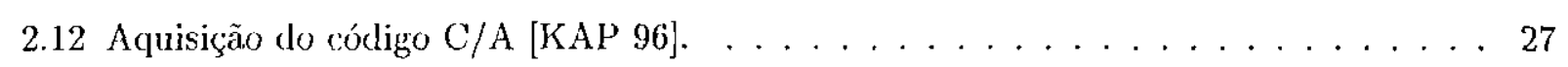

2.13 Constelação dos satélites GPS [KAP 96] . . . . . . . . . . . . . . . . 28

2.14 Diagrama de blocos simplificado de um receptor GPS $[K A P 96]$. . . . . . . . . 29

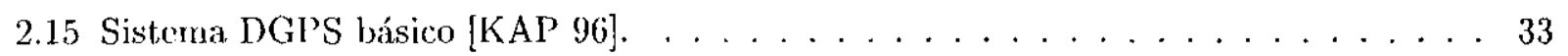

3.1 Diagrama de blocos do hardware embarcado na acronave. . . . . . . . . . . 40

3.2 Diagrama de blocos do hardware de extração de dados em solo. . . . . . . . . . . 42

3.3 Diagrama de fluxo de dados do sistema como um todo. . . . . . . . . . . . . 44

4.1 Distribuição física dos componentes do sistema. . . . . . . . . . . . . . 53

4.2 Montagem mecânica e integração dos módulos de hardware cm um encapsulamento

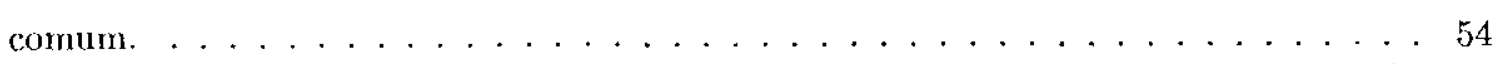

5.1 Diagrama de Huxo de dados do software executado no palmtop. . . . . . . . . . 56

5.2 Telas capturadas do palmtop - tela de controle da câmera fotográfica (a) e tela de

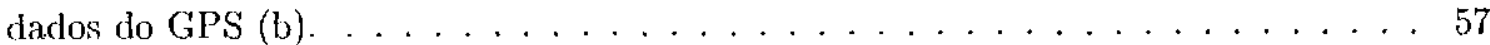


5.3 Diagrama de fluxo de dados do software do processador principal. . . . . . . . . . 58

5.4 Diagrama de fluxo de dados do software do controlador de câmera. . . . . . . . . . . 59

5.5 Diagrama de fluxo de dados do software de extração c coordenadas e quadros de vídeo. 60

5.6 Captura de tela da interface do extrator de coordenadas e imagens. . . . . . . . . 61

7.1 Detalhe da montagem do SciaGeo na acronave. . . . . . . . . . . . . 69

7.2 Mapa da regrião indicando os talhões monitorados. . . . . . . . . . . . . 70

7.3 Piloto e operador do SciaGeo a bordo da acronave com o hardware do SciaGeo acoplado (no canto inferior esquerdo da imagem) . . . . . . . . . . . . . 71

7.4 Detalhe de um veículo visto em solo por meio de imagens de baixa (a) e alta (b)

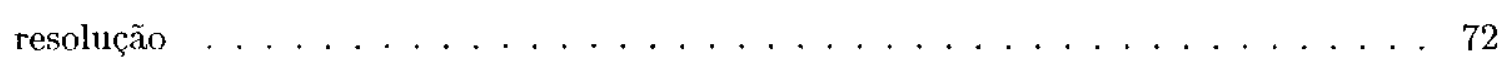

7.5 Imagens em escala reduzida de soja sem problemas (a) e com falhas de plantio (b) . 73

7.6 Imagens em média escala de soja sem problemas (a) e com falhas de plantio (b) . . . 74

7.7 Imagens efn grande escala de soja sem problemas (a) e com falhas de plantio (b) . . 74

7.8 Imagens em escala reduzida de milho sem (a) e com (b) presença de plantas invasoras. 75

7.9 Imagens cm grande escala de milho sem (a) e com (b) presença de plantas invasoras. 75

7.10 Nematóides crn área de soja - imagens original (a) e segmentada (b) . . . . . . . . 77

7.11 Falha de plantio em área de soja - imagens original (a) e segmentada (b). . . . . . 77

7.12 Doença em área de milho - imagens original (a) e segmentada (b) . . . . . . . . . . 78

7.13 Cobertura de solo em área de algodão - imagens original (a) e segmentaula (b). . . . 78

7.14 Mapa indicando a porcentagem da árca contendo solo nu nos pontos de amostragem. 79

A.1 Diagrama esquemálico da placa do conversor de níveis lógicos RS232/TIL . . . . . 89

A.2 Diagrama esquemático da fonte de alimentação chaveada utilizada pelo SciaGco. . . 90

A.3 Diagrama esqucmático do modem de 2400 bps utilizado para modılação c demodulação dos sinais digitais no canal de áudio da filmadora. . . . . . . . . . . . 90

A.4 Diagrama esquemático da placa controladora de câmera. . . . . . . . . . . . 91 


\section{Lista de Tabelas}

2.1 Elementos de orientação de uma fotografia aćrca [GRA 86] . . . . . . . . 19 


\section{Resumo}

Fotografias aéreas possuem aplicações nos mais variados tipos de atividades. Como exemplos, pode-se citar agricultura, vigilância, mapeamento e planejamento urbano, levantamento de malha rodoviária, levantamento topográfico c atividades militares, entre outras. É de grande importância a associação de imagens aćreas às coordenadas geográficas do local onde são obtidas. Fsse tipo de associação ć chamado de georeferenciamento, e é necessário para que seja possível utilizar, de forma satisfatória, os dados contidos nas imagens. Recentemente, o avanço da tecnologia na árca de posicionamento global tem fornecido sensores capazes de determinar coordenadas geográficas em tempo real com grande precisão. Isso permite a criação de sistemas que automatizam o processo de georeferenciamento das imagens a um baixo custo. Além disso, o uso de equipamentos de fotografia aérea de pequeno formato associado ao uso de aeronaves do tipo ultraleve como plataforma também tem permitido uma significativa redução no custo de obtenção de imagens aéreas. Neste trabalho de mestrado foi desenvolvido o SciaGeo, um sistema para aquisição automática de imagens aéreas georeferenciadas utilizando acronaves do tipo ultraleve. Foram obtidos bons resultados com o SciaGeo, por meio de testes em campo, realizados cm uma região agrícola, sobre culturas de soja e milho. Esses testes geraram imagens georeferenciadas de boa qualidade, permitindo a extração de informações importantes da cultura por meio de processamento digital de imagens. 


\begin{abstract}
Aerial photographs can be applied in a wide variety of activities. For example, they can be applied to agriculture, surveillance, urban mapping and planning, road survey, topographic mapping and military activities. There is a need for the connection of acrial imagery to the geographic: coordinates of the location where the images were acquired. This type of connection is called gcoreferencing, and it is required for the efficient use of the information extracted from the images. Recently, technology advances in global positioning systcms have provided sensors that are able to fix positions in real time with great accuracy. This allows the development of systems that automatc image georeferencing at a low cost. Furthermore, the use of small format photography in conjuntion with ultralight aircraft has allowed a cost reduction in aerial image acquisition. This work relates to the development of SciaGeo, an automatic system for acrial image acquisition and georeferencing using ultralight aircraft. Good results were achieved with SciaGeo in field tests. These tests werc done in agricultural locations, over soya and sweet corn ficlds. Good quality georeferenced images were obtained from the field tests, making it possible to extract information from them using digital image processing techniques.
\end{abstract}




\section{Capítulo 1}

\section{Introdução}

O grande avanço tecnológico verificado nos últimos anos na área de posicionamento global tem permiticlo a obtenção de dados georeferenciados de forma cada vez mais acessível. Uma das maneiras mais comuns de se obter esses dados é por mcio de imagcns aéréas, devido à sua abrangência geográfica e à facilidade de locomoção de uma aeronave no espaço.

A fotografia aérea vem sendo usada há bastante tempo, porém o equipamento tradicional para obtençr̃̃o das imagens é complexo e cxige um investimento muito alto, tornando o seu uso inviável para determinados tipos de aplicação. A diminuição do custo de sistemas de aquisição de imagens digitais (câmeras fotográficas digitais, por exemplo) e de posicionamento global tem aberto novas possibilidades.

Imagens aćreas georeferenciadas possuem aplicações em vários ramos de atividadc, como, por exemplo: agricultura [TOR 00] [Tri 00], planejamento urbano [FRè 98] [VAN 98], levantamcnto de malha rodoviária [NE'L 96] [BAR 93], análise de tráfego [ANG 02] [BEC 89], arqueologia [RIC 01] e operações militares, entre outras.

Uma das atividades que geram demanda por essas imagens atualmente é a agricultura de precisão. A essência da agricultura de precisão é a obtenção contínua de informaçōes espacialmente detalhadas da cultura, seguida da utilização adequada dessas informações para otimizar o manejo. Com a agricultura de precisão, define-se como aplicar no local correto, e no momento adequado, as quantidades de insumos necessários à produção agrícola, para áreas cada vez menores e mais homogêneas.

No solo, o teor de nutrientes, o teor de matéria orgânica, o pH, a umidade, a profundidade de camadas compactadas, entre outros parâmetros, apresentam variações que podem atingir até una ordem de grandeza de um local para outro ou de uma data para outra, na mesma área de produção. Toda a prática agricola convencional está baseada en tratar o campo como homogêneo, 
ignorando tais variações. A obtenção desses parâmetros em um determinado ponto a partir de imagens aćreas, com uma determinada precisão, pode fornecer os dados necessários para que o tipo de manejo seja definido de maneira dilerenciada para cada ponto da cultura.

Para que a aquisição das imagens se torne economicamente acessível, o equipamento utilizado deve ser de pequeno formato (filmes fotográficos de $35 \mathrm{~mm}$ ), em contraste ao cquipamento utilizado na fotografia áérea tradicional de grande formato, que possui um custo muito elevado. No caso de aquisição digital de imagens, a resolução do equipamento geralmente não é suficiente para que urna única imagem cubra uma área muito grande. Un sistema com baixo custo de operação deve produzir um grande número de imagens que, individualmente, cobrem uma pequena área do solo, e em conjunto, cobrem uma área maior.

A obtenção de imagens aéreas georeferenciadas de forma manual pode se tornar bastante custosa, principalmente quando o número de imagens é grande. Nesses casos, o trabalho torna-sc inviável, exigindo uma esforço muito grande. Para a agricultura de precisão, em particular, o tempo necessário para o processamento das imagens pode se tornar um problema, uma vez que a adoção de práticas de manejo deve ser feita imediatamente após a deteção do problema.

Um problema ainda maior quanto à obtenção de imagens aéreas de pequeno formato é a velocidade requerida para o georeferenciamento direto das imagens. $\Lambda$ eronaves de asa fixa (como ultraleves, por exemplo), possuem uma velocidade mínima de vôo; essa velocidade mínima de vôo implica um tempo mínimo para o georelerenciamento das imagens, já que isso deve ser feito cm tempo real. $\Lambda$ frẹüência de obtenção de imagens de pequeno formato em vôo é grande o suficiente para que se torne impossível registrar manualmente a coordenada geográfica no momento em que a imagem é obtida.

Pelos motivos citados acima, pode-se notar que a automatização da aquisição e do georeferenciamento das imagens se torna bastante útil no caso de imagers aćreas de pequeno formato.

Este trabalho tem por objetivo desenvolver o SciaGeo (Sistema de Captura de Imagens Gcoreferenciadas), um sistema que visa a aquisição de imagens aéreas de pequeno formato georefcrenciadas automaticamente, com foco na sua aplicação à agricultura de precisão. Essas imagens devem passar, posteriormente, por um processamento para a extração de características relevantes para o planejamento das alividades agrícolas.

Um dos objetivos do SciaGeo é a possibilidade de utilização cm aeronaves de pequeno porte, inclusive do lipo ultraleve. Essas aeronaves possuem um custo muito baixo de operação em relação às aeronaves utilizadas na fotografia aćrea convencional. Utilizando esse tipo de aeronave, o sistema porle ser utilizado em uma maior gama de aplicações e por diversos tipos de usuários. 


\subsection{Organização do Texto}

Está dissertação está dividida em oito capítulos. No segundo capítulo, é apresentada uma revisão da literatura, na qual são abordados diversos assuntos relacionados à obtenção de imagens aéreas, como Sistemas de Informação Gcográfica (SIGs), dispositivos para captura de imagens, fotografia aérea convencional e de pequeno formato, sisterna de posicionamento global GPS e sistemas de georeferenciamento de imagens aćreas.

O tercciro capítulo destina-se a apresentar uma análise de requisitos c uma especificação geral do SciaGeo, incluindo os requisitos funcionais e não funcionais do sistema, com diagramas gerais de hardware e software.

O quarto capítulo aborda com detalhes o projeto e implementação do hardware do SciaGeo, apresentando aspectos relativos às interfaces de hardware utilizadas, seleção de equipamento, desenvolvimento de hardware específico, metodologia de testes e montagem mecânica do equipamento.

No quinto capítulo são descritos o projeto c a implementação dos módulos de software do SciaGeo. São apresentadas descrições textuais e diagramas de fluxo de dados dos módulos, bem como aspectos das interfaces de comunicação e metodologia de testes.

O capítulo seis descreve como o sistema deve ser operado, desde a instalação até a recuperação dos dados resultantes.

No capitulo sete são apresentados os resultados obtidos na execução de uma missão real com o SciaGeo em uma propriedade rural. São avaliadas a viabilidade operacional do equipamento em condições reais e a qualidade dos dados gerados na missão.

Finalmente, o capitulo oito apresenta as principais conclusões resultantes do trabalho, incluindo as dificuldades encontradas durante o desenvolvimento e sugestōes de trabalho futuros bascados no SciaGco. 


\section{Capítulo 2}

\section{Contexto}

Neste capítulo é realizada uma revisão da literatura relacionada a este trabalho. Na seção 2.1, é apresentado um breve estudo sobre os conceitos associados a sistemas de informação geográfica (SIGs), sua descrição, funcionamento e aplicações. A seção 2.2 aborda o tema da acrofotogrametria, incluindo conccitos de fotografia em geral e de aerofotogrametria convencional e de pequeno formato. A seção 2.3 apresenta alguns dos tipos de dispositivos usados para captura de imagens, tanto digitais quanto analógicos, acompanhados de uma descrição de scu funcionamento. Alguns tópicos relacionados ao sistema de posicionamento global GPS săo apresentados na seção 2.4, incluindo um breve histórico da evolução de sistemas de navegação $\mathrm{e}$ uma explicação detalhada clo funcionamento do sistema GPS. Na seção 2.5, é feito um estudo sobre sistemas de georeferenciamento direto de imagens, inchnindo os problemas, vantagens e desvantagens associados à sua utilização. $\Lambda$ seção 2.6 trata de sistemas de plancjamento de missões de fotografia aćrea. Finalmente, na seção 2.7 são apresentadas algumas considerações finais sobre o capitulo. 


\subsection{Sistemas de Informação Geográfica}

O gcoprocessamento pode ser entendido como sendo a utilização de técnicas matemáticas e computacionais para o tratamento da informação sobre objetos ou fenômenos geograficamente identificados. O geoprocessamento tem sido empregado numa gama muito grande de aplicações em diversas áreas da Ciência, e tem contribuído para estudos de planejanento urbano e rural, meios de transporte, comunicaçōes e energia, entre outros. As ferramentas utilizadas para aplicar o geoprocessamento compōem um conjunto denominado Sistema de Informação Geográfica (SIG), muitas vezes chamado de GIS, do inglês Geographic. Information System, ou ainda de Sisterna de Informação Fspacial [MOR 01].

O campo de atuação dos SIGs é caracterizado por uma grande diversidade de aplicações. SIGs são sistemas de integração que unificam idéias desenvolvidas em várias áreas do conhccimento, como agricultura, botânica, computação, economia, matemática, fotogrametria, zoologia e gcografia, cntre outros. Por ser largamente utilizado por um grupo heterogêneo de usuários, o termo SIG é relalivamente difícil de ser definido. Um outra dificuldade na definição do termo SIG deriva do fato de que muitas pessoas acreditam que o foco central é o conjunto de hardware e software, enquanto que outros argumentam que o elemento chave é o processamento da informação ou inesmo as aplicações [M

Uma das definiçōes mais utilizadas para o termo SIG é a de Burrough apud [M "um poderoso elenco de ferramentas para coletar, armazenar, recuperar, transformar e exibir dados espaciais do mundo real".

Em um SIG, a realidade é representada como uma série de características definidas de acordo com dois elementos de dados: o elemento geográfico e o atributo. O elcmento de dados geográfico é usado para fornecer uma referência para o atributo. Por exemplo, fronteiras administrativas, redes hidrográficas e localizações de picos no relevo são elementos geográficos utilizados para fornecer uma referência para, respectivamente, censo, fluxo de água e elevação do terreno. Em SIGs, o elemento geográfico é visto como mais importante do que o atributo, é uma das principais características que diferenciam os SIGs de outros sistemas de informação [MAG 91].

Na subseção 2.1.1 são apresentados os componentes básicos de um SIG. Algumas aplicações de SIGs são citadas na seção 2.1.2. 


\subsubsection{Componentes de um SIG}

Numa visão abrangente, pode-se dizer que um SIG é composto de cinco componentes independentes, porém interligados uns aos outros através de funções específicas. Os componentes do SIG são: entrada e integração de dados, funções de consulta e análise espacial, visualização e plotagem, e banco de dados geográfico (figura 2.1). Cada sistema, em função de seus objetivos e necessidades, implementa esses componentes de forma distinta, mas todos estão usualmente presentes cm um SIG $[C \wedge M 96]$.

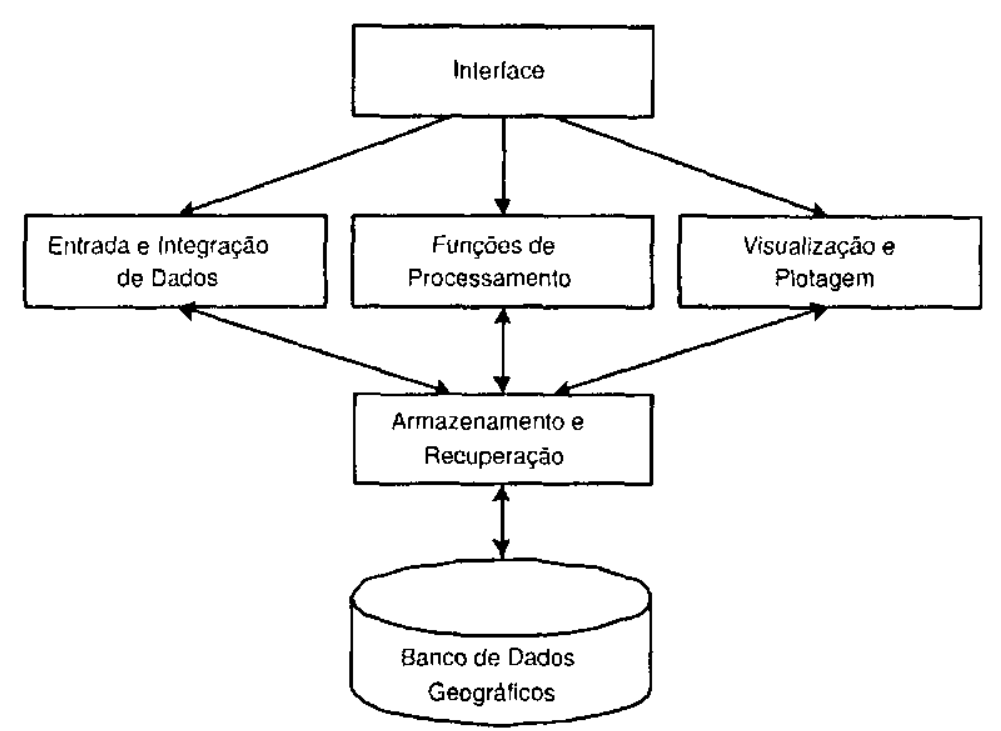

Figura 2.1: Estrutiura geral de un Sistema de Informaçōes Geográficas [CAM 96].

\section{Interface}

A interface é composta de um conjunto de funções que serve como suporte de entrada e integração dos dados. Em sisternas atuais, as funções relacionadas à interface são acionadas geralmente através de memus.

\section{Entrada e Integração de Dados}

A entrada refere-se a todos os aspectos de aquisição de dados espaciais contidos em mapas, fotografias aéreas, imagens de satélites, dados de campo, dados digitalizados, etc. Como os dados provêm de várias fontes, quase sempre é necessário converter esses dados para um único formato que possa ser interpretado pelo SIG. 


\section{Funçōes de Processamento}

As funções de processamento são naturalmente dependentes dos tipos de dados envolvidos. A análise geográfica engloba funções como superposição, ponderação, medidas (área, perímetro), mapas de distância, tabulação cruzada, dentre outras. O processamento digital de imagens envolve funções como retificação, contraste, filtragem, realce e classificação. Modelos numéricos de terreno permitem a geração de mapas de declividade e aspecto, cálculo de volumes, análise de perfis, além da própria geração do modelo a partir de pontos esparsos ou linhas, entre ontras funções. Operações sobre redes incluem caminhos ótimos, caminbos críticos e ligação topológica. Já as consultas aos bancos de dados podem ser espaciais ou não.

\section{Visualização e "Plotagem"}

Este componente, como o próprio nome diz, é utilizado para visualizar e "plotar" os dados, sejam espaciais ou alfanuméricos. Para auxiliar nesta tarefa empregam-se monitores de vídeo, impressoras e plollers.

\section{Banco de Dados Geográfico}

Um banco de dados é, basicamente, um conjunto de dados estruturados de forma a facilitar o acesso a determinadas informações que descrcvem determinadas cntidades do mundo real. Podemos citar, como exemplo, um banco de dados de funcionários de uma cmpresa que contém três tipos de dados: dados pessoais (nome, endereço, dados de documentos, etc), dados funcionais (cargo, data de admissão, etc) e dados para pagamento (salário base, faixa salarial, etc).

Um banco de dados geográficos (BDG) difere de um banco de dados convencional por armazenar dados sobre a localização das entidades. No exemplo anterior, o banco de dados convencional pode ser transformado em BDG se for introduzido dados que associem cada funcionário a uma localização geográfica do local onde mora ou onde trabalha. Neste caso, foi necessário introduzir uma referência geográfica em termos de pares de coordenadas geográficas [MOR 01].

Tradicionalmente, os SIGs armazenavam os dados geográficos em arquivos internos. Este tipo de solução vem sendo substituído pelo uso cada vez maior de Sistemas Gerenciadores de Banco de Dados (SGBD).

\subsubsection{Aplicações de SIGs}

Entre as árcas de aplicação de SIGs, pode-se citar [LAU 92]: 
- Sistemas de sensoriamento remoto;

- Design apoiado por computador (CAD - Computer Aided Design);

- Mapeamento temático;

- Cartografia marítima;

- Modelagem de superfícies;

- Modelagem ambiental;

- Agricultura de precisão;

- Gerenciamento de recursos;

- Plancjamento de transportes;

- Geomarketing;

- Arqueologia;

- Exercícios militares.

O domínio de aplicações em SIG está se ampliando cada vez mais, acompanhando a evolução dos dispositivos de coleta c as facilidades computacionais em geral.

Um fenônteno geográfico pode ser analisado de forma e com precisão diferentes, dependendo do objetivo da aplicação. Dessa forma, um mesmo conjunto de dados armazenados pode ter tratamentos distintos. Por exemplo, dados pluviométricos coletados em um conjunto de estações pluviométricas ao longo do tempo podem ser interpolados para determinar a distribuição de chuvas em certas regiões durante um período, visando planejar atividades de plantio. Os mesmos dados podem ser combinados com informaçōes sobre a bacia hidrográfica das regiões, declividade e permeabilidade do solo, para auxiliar estudos de erosão. 


\subsection{Dispositivos de Captura de Imagens}

Nesta seção são apresentados conceitos relacionados a dispositivos de captura de imagens. Na subseção 2.2.1 são considerados os aspectos gerais de uma câmera fotográfica. A subseção 2.2.2 trata de câmeras fotográficas digitais. Finalmente, na seção 2.2 .3 são descritos aspectos de funcionamento de câmeras filmadoras.

\subsubsection{Câmeras Fotográficas}

Componentes de uma Câmera Fotográfica

A figura 2.2 apresenta os principais componentes encontrados cm uma câmera fotográfica típica. Esses componentes são importantes porque influem diretamente na formação da imagem final. São eles:

- Lente;

- Diafragma;

- Obturador;

- Filme.

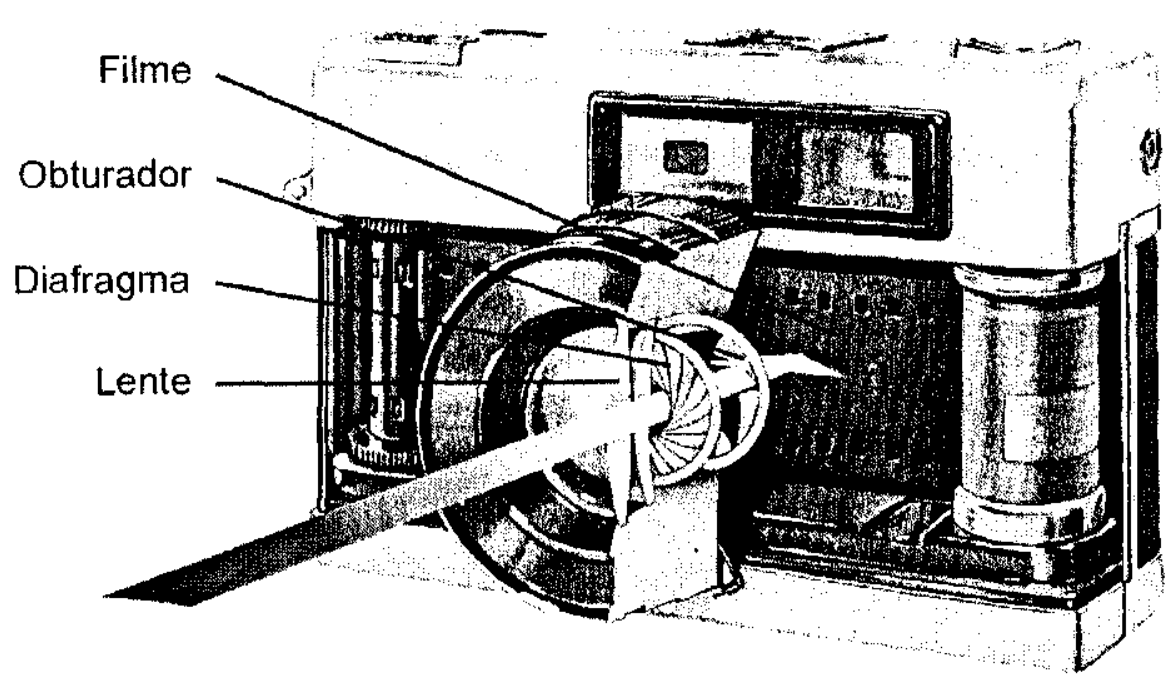

Figura 2.2: Principais componentes de uma câmera fotográfica (adaptado de [HED 79])

Esses componentes e sua função na obtenção da imagem são apresentados nas subseções seguintes. 


\section{Lente}

Uma lente convergente posicionada na parte frontal da câmera transmite os raios de luz vindos de cada parte da cena e focaliza-os em uma superfície plana. Raios de luz das partes superior e inferior c direita c esquerda da ccna são focalizadas em pontos diametralmente opostos na superfície plana. Isso produz uma imagem invertida, bem definida e detalhada da cena [LAN 78].

Uma lente pode ser simples ou composta. Una lente simples é formada por um único bloco de vidro com forma semelhante a um disco, cnquanto que uma lente composta ć formada por várias lentes simples alinhadas sobre um mesmo eixo, o eixo ótico. As lentes utilizadas $\mathrm{cm}$ câmeras fotográficas são geralmente compostas, para gerar imagens melhores, com poucas distorções e aberrações.

Desconsiderando-se os detalhes de construção, as lentes de câmeras fotográficas são, em cssência, semelhantes a lentes convexas simples em suas propriedades de formação de imagens [J $\Lambda \mathrm{C} 88$ ]. Se um objeto está próximo à lente, a posição e o tamanho da imagem podem ser determinados considerando-se a refração da luz vinda de dois pontos extremos do objeto. Na figura 2.3 , isso é apresentado para uma lente simples.

Por aproximação, pode-se considerar que um determinado objeto suficientemente distante se encontra no infinito; todos os raios de luz vindos de algum ponto do objeto são considerados paralelos. Imagens de objetos posicionados dessa forma são formadas sobre um plano chamado plano focal principal, que intercepta o cixo ótico no foco. $\Lambda$ distância do foco até a lente é chamada de distância focal (vide figura $2.3($ a))).

Como imagens de objetos a diferentes distâncias são formadas em planos diferentes, muitas câmeras possuem controles que permitem variar a distância entre a lente e plano de formação da imagem (plano do filme fotográfico). Imagens formadas em planos distantes do plano do filme aparecem borradas na imagem. A menor distância praticável entre a lente e o plano do filme é igual à distância focal. Quando ajustada dessa forma, a câmera pode focalizar objetos distantes, e diz-se que cla está focada no infinito. Em câmeras simples, que não possuem controle de foco, o foco gerahnente é ajustado para o infinito.

$\Lambda$ escala da imagem (ou aumento) é definida como a relação entre o tamanho do objeto real fotografado c o tamanho da representação do objeto na imagem gerada. A escala da imagem depende dirctamente da distância focal da lente da câmera. Para objetos distantes, e quando a câmera está focada no infinito, a escala da imagem é dada por

$$
S=\frac{f}{D}
$$




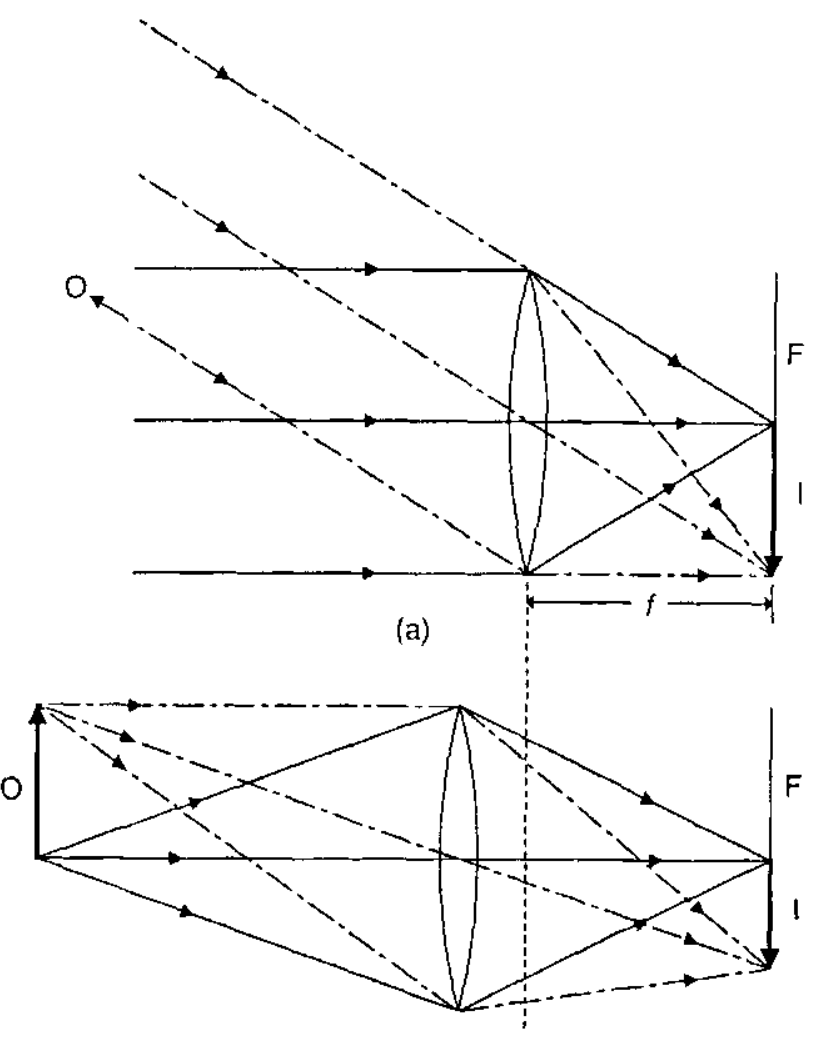

(b)

Figura 2.3: Formação de imagens por uma lente de uma câmera [JAC 88].

onde $S$ a escala da imagem, $f$ é a distância focal da lente e $D$ é a distância do objeto em relação à câmera.

A distância focal da lente também determina o ângulo de visão para um determinado formato de filme. () ângulo de visão é definido como o ângulo projetado pela diagonal do filme com relação à lente,e, quando a câmera está focada no infinito (figura 2.4). O ângulo de visão $\theta$ é dado pela fórmula:

$$
0=2 \arctan \left(\frac{K}{2 f}\right)
$$

onde $K$ é a diagonal do filme e $f$ é a distância focal da lente.

Vale notar que existem lentes de câmeras com distância focal variávcl. Essas lentes são chamadas de varifocais ou lentes com zoom. 


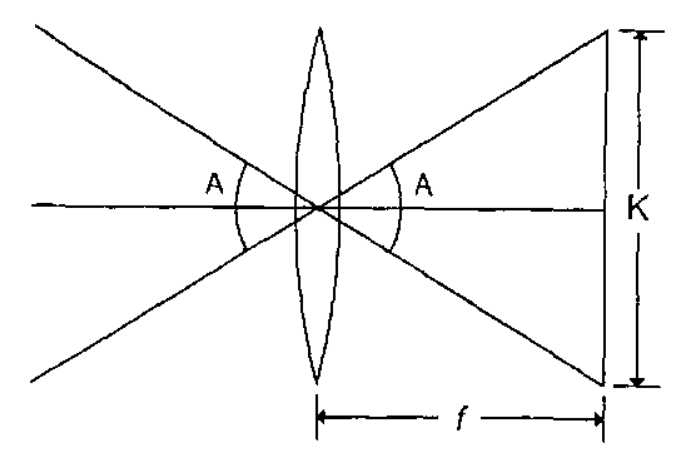

Figura 2.4: Ângulo de visão [JAC 88].

\section{Diafragma}

A intensidade da luz que passa por uma lente fotográfica é limitada pelo diafragma. Em algumas câmeras, a abertura do diafragma è fixa; em outras o diafragma consiste de um disco contendo vários orifícios de diferentes aberturas. A maioria das lentes, no entanto, utiliza um diafragma $\mathrm{cm}$ forma de íris, que possui lâminas (folhas) que podem ser movidas de modo a formar una abertura circular de diâmetro variável, conforme pode ser visto na figura 2.5 [JAC 88].

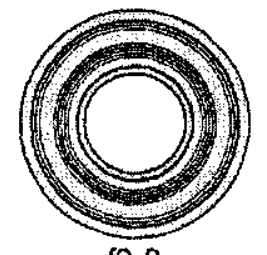

f2.8

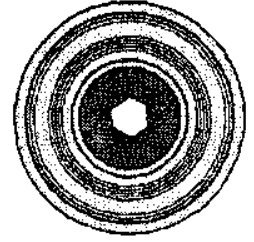

f8

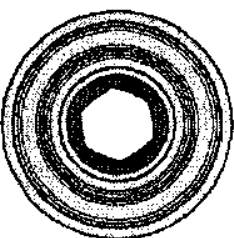

f4

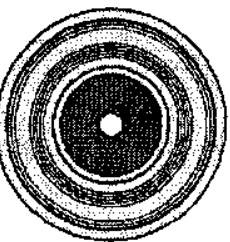

f11

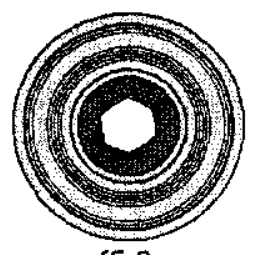

f5.6

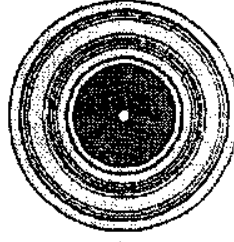

f16

Figura 2.5: Diafragma em forma de íris [IED 79].

Aberturas de diafragma são ajustadas em função de frações da distância focal da lente, chamadas de f-stops. Uma abertura de f8 significa que a razão entre o diâmetro da abertura c a distância focal da lente é de 1/8. Os f-stops são organizados em uma sequiência padrão que começa em $\mathrm{f} 1$, passando por $\mathrm{f} 1.4, \mathfrak{f}, \mathrm{f} 2.8, \mathrm{f} 4, \mathrm{f} 5.6, \mathrm{f} 8, \mathrm{f} 11, \mathrm{f} 16, \mathrm{f} 22$, e atingindo aberturas ainda menores.

Além de clarear on escurecer a imagem, variaçõos na abertura do diafragma possuem um outro efeito importante: elas afetam a profundidade de campo, que é a árca satisfatoriamente nítida atrás e ì frente do objeto focado [HED 79]. 
Um outro fator importante afetado pela abertura do diafragma é a distância hiperfocal, que corresponde à menor distância que um objcto pode estar da câmera e ainda aparecer nítido na imagem, quando a câmera está focada no infinito. A distância hiperfocal $D H$ pode scr calculada da seguinte mancira [WAR 96]:

$$
D H=1000 \times \frac{f}{A}
$$

onde $f$ é a distância focal da lente e $A$ é a abertura do diafragma. Por exemplo, com uma lente de distância focal de $35 \mathrm{~mm}$ e uma abcrtura de diafragma de f16, a distância hiperfocal é de

$$
\frac{1000 \times 35 \mathrm{~mm}}{16}=2,2 \mathrm{~m}
$$

\section{Obturador}

Existem dois tipos básicos de obturador. O primeiro é localizado na lente da câmera c consiste de lâminas de metal que formam uma barreira à luz e giram de forma a permitir a exposição (vide figura 2.6 (a)). O segundo tipo de obturador é localizado próximo ao plano focal, e é composto de duas barreiras com abcrturas retangulares que, com movimentos combinados, libcram a passagem de luz por um determinado tempo (vide figura 2.6 (b)).

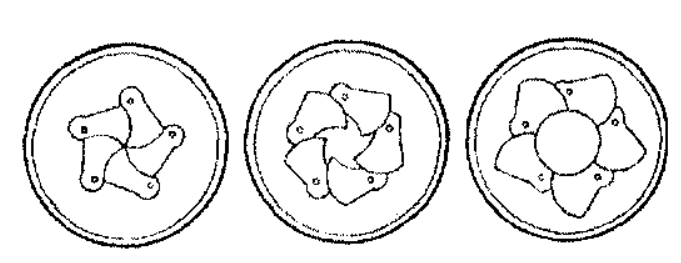

(a)

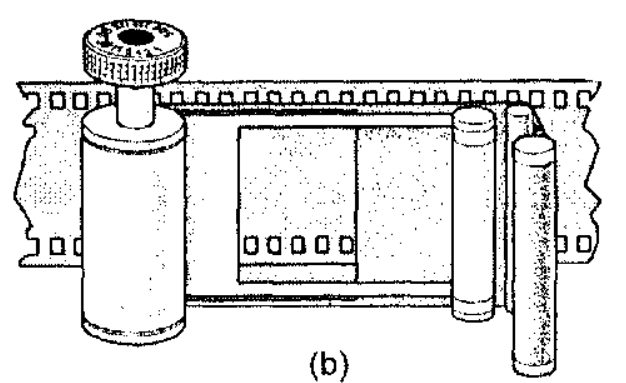

(b)

Figura 2.6: Tipos de obturador de umi câmera fotográfica [HED 79].

Além de controlar o momento exato da exposição do filme à. luz, o obturador é responsável por regular a duração da exposição. Uma velocidade menor do obturador torna o tempo de exposição mais longo, o que implica em uma imagem mais clara, pois mais luz atinge o filme. Analogamente, velocidades maiores do obturador implicam em inagens mais escuras.

O tempo de exposição determina também como objetos em movimento aparecem na imagem. Com maior tempo de exposição, eles aparecem borrados, enquanto que tempos de exposição menores congelam a ação. 


\section{Filme}

O filme cm uma câmera fotográfica convencional é uma película contendo material químico sensivel à luz. Após a exposição, o filme é processado (revelado) para gerar a imagem final.

Os dois parâmetros básicos relativos a unn filme colorido são o tamanho e a scnsibilidade. O tarnanho deve ser compatível com a câmera fotográfica utilizada e é normalmente dado em função da largura do filme. O filme mais comum é o de 35mm (largura), com dimensões da imagem de 36 $\mathrm{x} 24 \mathrm{~mm}$.

A sensibilidade do filme é geralmente dada na escala padräo ISO. O número ISO é proporcional à sensibilidade do filme. Por exemplo, um filme ISO 200 é duas vezes mais sensível do que um filme ISO 100. A determinação da sensibilidade do filme deve ser feita em função das condiçõcs de iluminação da cena e da velocidade e abertura desejada para a exposição.

\subsubsection{Câmeras Fotográficas Digitais}

Câmeras fotográficas digitais possuem a mesma estrutura básica de uma câmara fotográfica convencional. A principal diferença se encontra no mecanismo de registro da imagem. Em vez de um filme químico, câmeras digitais ntilizam um dispositivo de estado sólido (sensor de imagem), para registro da imagem. Os sensores de imagen são chips de silício que contêm milhões de diodos fotosensíveis chamados fotocélulas. Cada uma das fotocélulas reage à luz que a atinge acumulando uma carga; quanto maior a intensidade da luz, maior a carga. Essa carga então é convertida para dados numéricos em formato digital, que são processadas para exibição em uma tela ou então impressas.

Atualmente existem dois tipos de sensores de imagens, quanto ao processo de fabricação: CCD ou CMOS. Ambos são baseados no conceito de fotocélulas. Sensores CCD são mais caros e oferecem melhır qualidade de imagem. Sensores CMOS possuem um processo de fabricação mais simples c barato e são de mais fácil integração, porém apresentam imagens de pior qualidade se comparados aos sensores tipo CCD. O recente aprimoramento dos sensores CMOS vem reduzindo gradualmente as suas desvantagens em relação aos sensores CCD. Para uso em câmeras fotográficas digitais, os sensores do tipo CCD são mais comuns atualmente [LIT 01] [BLA 99].

Una fotocélula captura apenas a intensidade da luz incidente, e é incapaz de detcrminar a cor da luz. A maneira mais utilizada para registrar cor em câmeras digitais é com o uso de filtragem. Nessa técnica, um filtro é colocado sobre cada fotocélula para adquirir cores diferentes. O padrão de filtros mais utilizado é o de Bayer. Esse padrão alterna entre uma linha de filtros vermelhos e verdes e uma linha de filtros azuis e verdes (figura 2.7). Existem mais filtros verdes porque o olho humano não é igualmente sensivel a todas as cores. 


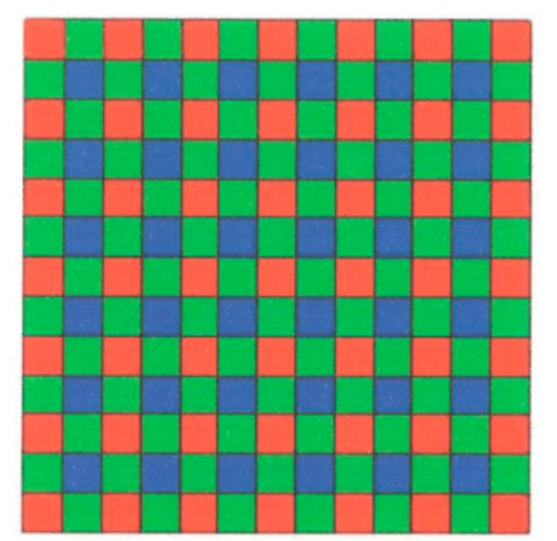

Figura 2.7: Filtro de Bayer [NIC 03].

A saída de um sensor com um filtro de Bayer é um mosaico de pixels vermelhos, verdes e azuis de intensidades diferentes. As câmeras digitais utilizam um algoritmo de interpolação para converter o mosaico de cores separadas em um mosaico de cores reais com o mesmo tamanho. A cor verdadeira de um pixel é determinada por uma média dos valores dos pixels mais próximos [NIC 03].

Uma das principais características de uma câmera fotográfica digital é a sua resolução. Geralmente, a resolução é dada em função do número de fotocélulas no sensor de imagem da câmera. No entanto, a resolução em pixels das imagens resultantes é sempre menor do que a resolução do sensor, pois algumas fotocélulas da borda do sensor não são utilizadas para obtenção da imagem.

Sensores de imagem em câmeras digitais também são classificados usando números equivalentes à escala ISO de filmes químicos. Algumas câmeras possuem sensores com valores ISO variáveis. Em situações de baixa luminosidade, é possível aumentar o valor ISO do sensor amplificando o seu sinal (aumentando o ganho).

A função do obturador em uma câmera digital pode ser realizada por três tipos de mecanismos [CUR 03]:

- Sensores bloqueados eletronicamente: esses sistemas utilizam o próprio sensor para controlar eletronicamente o tempo de exposição;

- Obturadores eletro-mecânicos: são dispositivos mecânicos controlados eletronicamente;

- Obturadores eletro-óticos: são dispositivos controlados eletronicamente posicionados na frente do sensor de imagem que alteram a opacidade do meio percorrido pela luz. 
As câmeras fotográficas digitais nccessitam de dispositivos de armazenamento dos dados obtidos pelo sensor de imagens. Para isso, as câmeras atuais utilizam cartões de memória Flash (disponíveis em diversos padrões), disquetes, discos rígidos compactos on mesmo CDs regraváveis.

Cámeras digitais atuais de alta resolução geram uma quantidade de dados muito grande, e tendem a utilizar dispositivos de armazenamento cada vez menores. Apesar do constante aumento de densidade das mídias de armazenamento, muitas vezes é necessário que as imagens passem por algum algoritmo de compressão antes de serem gravadas. O algoritmo mais utilizado para compressão em câmeras digitais ć o JPEG, com diferentes níveis qualidade.

\subsubsection{Câmeras Filmadoras}

Câmeras filmadoras (ou simplesmente filmadoras) possuem a mesma estrutura básica de câmeras fotográficas digitais. A diferença principal é a de que câmeras filmadoras capturam e armazenam imagens a uma taxa rápida e constante, do modo a criar uma seqiiência de vídeo. Gcralmente as imagens capturadas possuem menor resolução se comparadas a imagens de câmeras fotográficas digitais, devido a limitações de capacidade de armazenamento do vídeo.

Existem câmeras filmadoras analógicas e digitais. A diferença entre elass se dá apenas quanto à maneira como os dados são armazenados durantc a gravação. Todo o processo de aquisição da imagem é semelhante: para os dois tipos.

Quanto à parle ótica, muitas câmeras filmadoras possuem ajustes de foco o de abertura de diafragma antomálicos. Como as filmadoras são utilizadas para capturar objetos em movimento e em diferentes condições de luminosidade, o ajuste manual desses parâmetros é inviável. Algumas câmeras filmadoras também possuem ajuste automático de velocidade do obturador. A maior parte das filmadoras possui ajuste de distância focal $(z \circ o m)$. Além das imagens, as filmadoras são também projetadas para capturar e armazenar som, seja de forma analógica ou digital [HAR 03]. 


\subsection{Fotografia Aérea}

Nesta seção são apresentados conceitos relacionados a fotografias aéreas. Na subseção 2.3 .1 são citados conceitos de aerofotogrametria. A subseção 2.3.2 apresenta um cstudo sobre fotografia aćrea digital e de pcqueno formato, c sua comparação com a fotografia aćrea convencional. Na subseção 2.3.3 é feita uma breve pesquisa sobre o 1 sso de aeronaves do tipo ultraleve como uma plataforma para fotografia aérea.

\subsubsection{Aerofotogrametria}

A palavra fotogrametria, derivada de três palavras de origem grcga, tem o seguinte significado: luz, descrição e medidas. Ela pode ser definida como a ciência e a arte de se obter medidas dignas de confiança por meio de fotografias. O comprimento de um aeroporto, de uma rua, a posição de uma auto-estrada, o traçado de curvas de nível, a determinação da elevação de uma queda dágua e a posição relativa de dois automóveis depois de uma colisão são alguns exemplos da quase ilimitada aplicação da fotogrametria [MAR 90].

As principais aplicações da fotogrametria são a confecção de mapas topográficos, temáticos e mosaicos. O mapa assume características especiais segundo a finalidade para a qual ć claborado; em função desses propósitos diretos, define-se a escala da fotografia, o tipo de câmera, o tipo do filme, etc. [PAR 86]

A fotogrametria é freqüentemente dividida em categorias. De acordo com o tipo, pode-se dividí-la em dois tipos básicos [MAR 90]:

- Fotogrametria terrestre: utiliza fotografias tiradas da Terra, com o cixo ótico da câmera na direção horizontal;

- Fotogrametria aćrca: utiliza fotografias obtidas com câmeras montadas em aeronaves.

Devido ao avanço da tecnologia, essa classificação básica pode ser estendida incluindo-se um t.erceiro tipo: a fotogrametria espacial. Nela, são ntilizadas imagens obtidas a partir de plataformas localizadas no espaço, como satólites artificiais, por exemplo [PAR 86].

Neste trabalho são abordados apenas os conceitos relacionados à fotogrametria aérea, ou aerofotogrametria, visto que o SciaGeo visa auxiliar a aquisição de imagens georeferenciadas a bordo de aeronaves.

A primeira grande gucrra mostrou a importância da fotogralia aérea não só para fins militares, mas tambérn para mapeamento e observações de caráter geral. Depois da gucrra, com a 
experiencia adquirida por militares c civis, foram criados nos Estados Unidos muitos departamentos de fotogrametria, onde o mapeamento e a interpretação das imagens constituíam o principal objetivo.

\section{Tipos de Fotografia Aérea}

Segundo a posição do cixo ótico da câmera, a fotografia aérea pode ser vertical, oblíqua alta ou oblíqua baixa:

- Fotografia Vertical: é tirada com o eixo ótico da câmera coincidindo com a linha vertical ou a dirção da força da gravidade. Na prática, considera-se ainda verticais as fotografias cujo cixo ótico possui inclinação de atć cinco graus [WAR 96] [GRA 86] (figura 2.8 (a));

- Fotografia Oblíqua Alta: apresenta o eixo ótico com um grande desvio em relação à linha vertical, de modo que a linha do horizonte aparece na imagem final (figura 2.8 (b));

- Fotografia Oblíqua Baixa: apresenta o cixo ótico com um pequeno desvio em relação à linha vertical, de modo que a linha do horizonte não aparece na imagem final (figura 2.8 (c)).

A figura 2.8 ilustra os tipos de fotografia aérea citados, juntamente como a representação de como uma grade regular sobrc o solo seria representadia na fotografia.

\section{Geometria da Fotografia Aérea}

Como a fotografia é baseada em projeções centrais, um fator importante a ser considerado é a localização do centro da fotografia. Existem três pontos associados a uma fotografia aćrea [WAR 96]:

- Ponto principal: é o centro geométrico da fotografia, que coincide com a interseção das linhas traçadas entre cantos opostos;

- Nadir: é o ponto verticalmente abaixo da aeronave;

- Isocentro: é ponto médio do segmento de reta que vai do ponto principal até o nadir.

Em uma fotografia aérea perfeitamente vertical, o ponto principal, o nadir e o isocentro são coincidentes.

No total, existem nove elementos que determinam a orientação de uma fotografia aćrea (tabela 2.1). Seis elementos estão associados à orientação da câmera no espaço, c incluem três posiçôes da câmera en relação ao solo $(X, Y, Z)$ e três rotações da câmera $(\phi, \omega, \kappa)$. Esses seis 

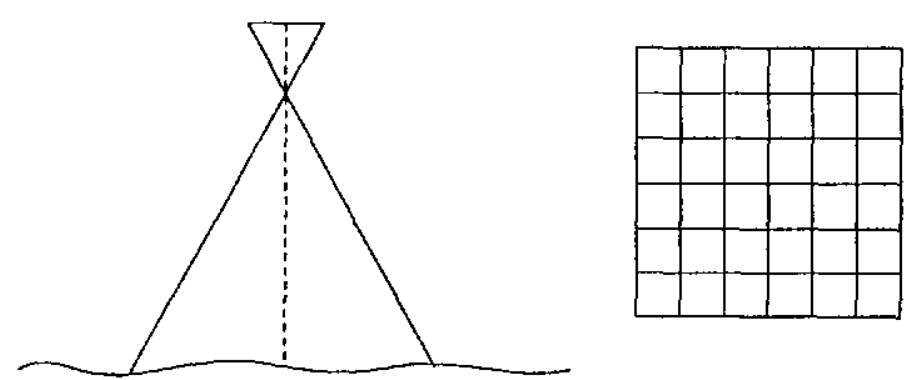

(a) Vertical
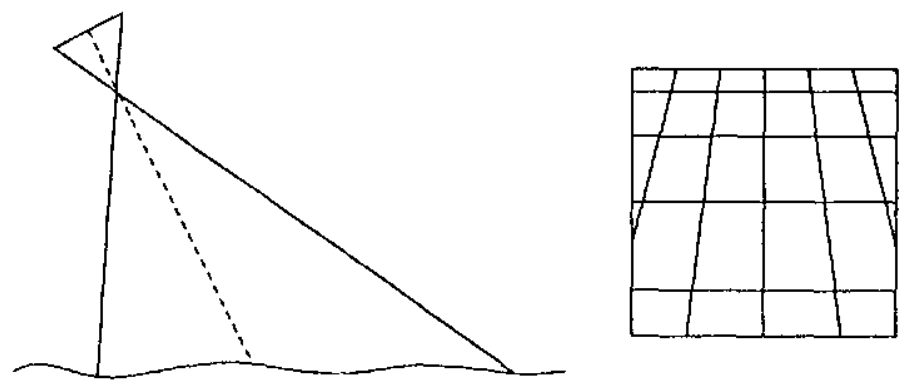

(b) Oblíqua Baixa
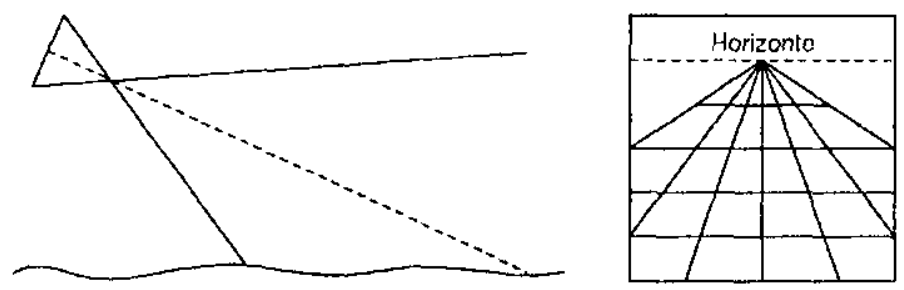

(c) Oblíqua Alta

Figura 2.8: Tipos de fotografias aéreas segundo o eixo ótico da câmera (adaptado de [MAR 90]).

T'abela 2.1: Elementos de orientação de uma fotografia aérea [GRA 86].

\begin{tabular}{|c|c|}
\hline \multicolumn{2}{|c|}{ Orientação Externa } \\
\hline \hline Três Posições & Três Rotações \\
\hline$X, Y, Z$ & $\phi, \omega, \kappa$ \\
\hline \hline \multicolumn{2}{|c|}{ Orientação Interna } \\
\hline Distância Focal & Posição do ponto principal \\
\hline
\end{tabular}

elementos constituem a orientação externa da fotografia. Os outros três elementos cstão relacionados à geometria interna da câmera e são a distância focal, c as posições $x$ e $y$ do ponto principal na fotografia. Esses três elementos constituem a orientação interna da fotografia [GRA 86]. 


\section{Escala de uma Fotografia Aérea}

Deve-se notar que uma fotografia não é um mapa, pois um mapa possui uma escala comum, enquanto que uma fotografia aérea não. Isso significa que todos os objetos em um mapa possuem a mesma escala, enquanto que objetos em uma fotografia aérea possuem cscalas diferentes. Isso deriva do fato de que a fotografia aérea é produto de uma projeção central ou perspectiva, enquanto que um mapa é produto de uma projeção ortográfica, conforme ilustrado na figura 2.9 [WAR 96].

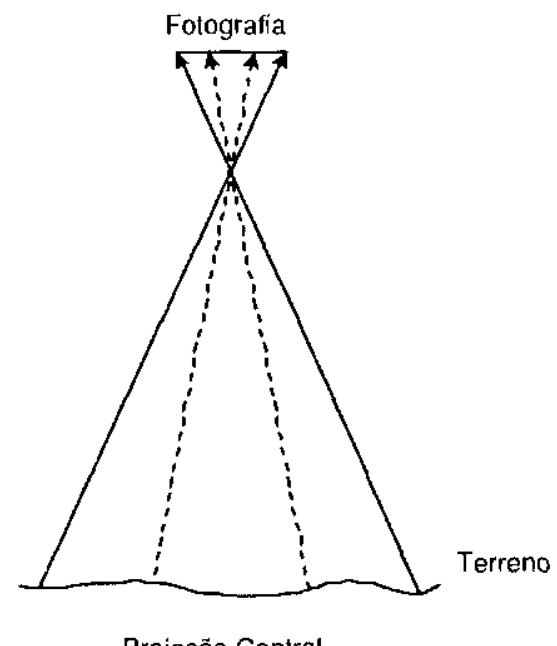

Projeção Central

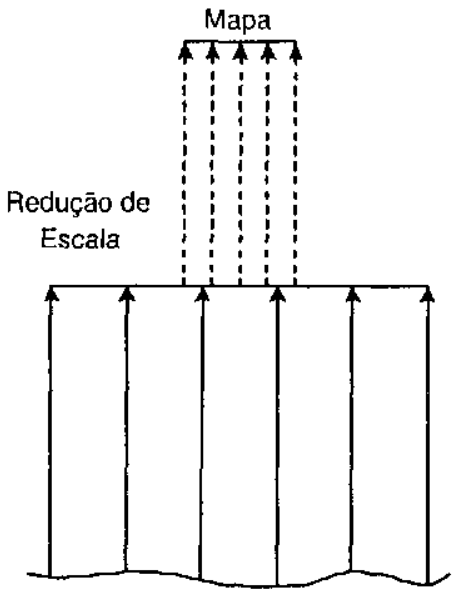

Projeção Ortográfica

Figura 2.9: Projeções central e ortográfica.

A escala em fotografias e mapas é definida como a razão entre a distância cntre dois pontos na fotografia (ou mapa) e a distância cutre os pontos correspondentes no solo. Em outras palavras, escala é uma expressão que denota que uma unidade de distância cm uma imagem representa um

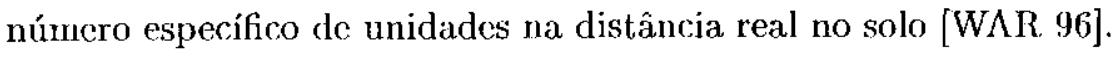

Há dois tipos de cscala: escala pontual e escala média. Quando se fala em uma escala descjada para uma missão de fotografia aérea, refere-se à escala média. A escala média em um projeto é raramente idêntica para todas as imagens, pois cada uma possui características próprias que influenciam a escala: diferenças na orientação da câmera, mudanças na altitude de vôo e variação do terreno.

Em uma sitıação hipotética onde o terreno é completamente plano e a fotografia é perfeitamente vertical, temos uma escala constante ao longo de toda a fotografia; porém, isso raramente acontece. Só é possível obter uma escala precisa quando se trabalha com um único ponto a uma determinada altitude. Para uma câmera focada no infinito, temos a escala pontual $S_{p}$ : 


$$
S_{p}=\frac{f}{H}
$$

onde fé a distância focal da lente e $I I$ é a altura em relação ao solo.

\section{Distorções e Deslocamentos}

Distorçồcs são definidas por [WAR 96] como mudanças na posição da imagem em uma fotografia que alteram as características de perspectiva da imagem. Já deslocamentos são definidos como mudanças na posição da imagem que não alteram as características de perspectiva da imagem.

Como causas de distorção, temos: variações de tammnho do filme fotográfico, refração dos raios de luz na atmosfera, aberraçoos da lente e movimentação da imagem. Como causas de deslocimento, temos: a curvatura da Terra, desvio da câmera (tilt $)$ e variações no relevo.

Do ponto de vista do usuário de equipamento fotográfico, de todos os fatores citados, a maioria depende do uso de equipamento mais sofisticado ou pode ser desprezada. Assim, os rnaiores problemas a serem tratados são as variações no relevo (figura 2.10) e desvios da câmera, que afetam a escala das imagens de maneira mais significativa [WAR 96].

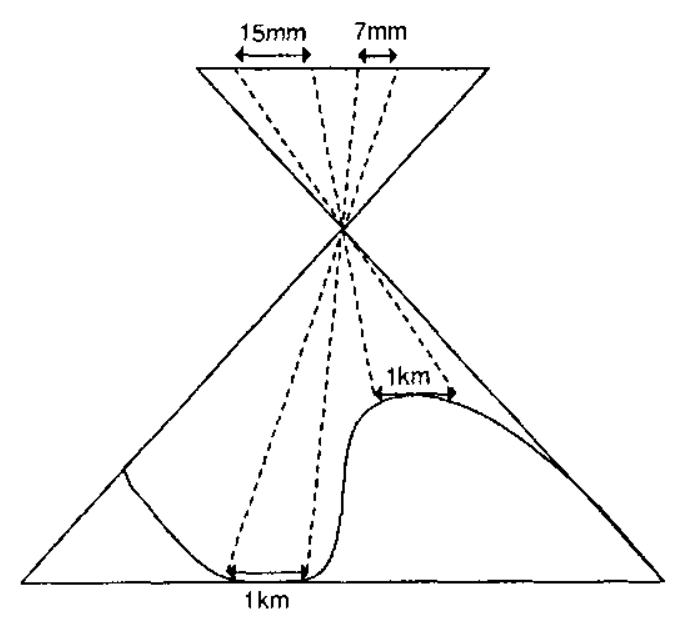

Figura 2.10: Como variaçõcs no relevo podem afetar a escala $\mathrm{em}$ uma fotografia [WAR 96].

\subsubsection{Fotografia Aérea Digital e de Pequeno Formato}

O uso de fotografia aćrea de pequeno formato em mapeamento aćreo vem sendo estudado e cxperimentado já há algum tempo [WAR 96]. Apesar das limitações de resolução desse tipo de fotografia, o baixo custo das câmeras e filmes utilizados e a possibilidade de uso de aeronaves menores o fazem 
uma alternativa viável para uma gama maior de aplicações, quando comparado à fotografia aćrea convencional.

Scgundo [PAR 86], as câmeras a serem utilizadas na acrofotogrametria devem possuir algumas caractcrísticas específicas, dentre elas:

- Lentes de alto padrão geométrico, isentas de abcrraçõcs e distorçôes, e com alto poder de resolução;

- Distância focal fixa e calibrável;

- Obturador de alta velocidade e alto rendimento;

- Grande capacidade de armazenamento de filme;

- Formato grande, com lados precisos;

- Filme de alta sensibilidade;

- Uso de dispositivos especiais como o intervalômetro (utilizado para disparar as fotografias no momento adequado).

Por muito tempo, essas características só estavam disponíveis em câmeras especiais, desenvolvidas especificamente para a obtenção de fotografias aéreas. Pode-se notar, entretanto, que com o avanço da tecnologia na área de folografia, muitas dessas características são hoje encontradas em câmeras fotográficas convencionais (não específicas para aerofologrametria). Características como distância focal calibrável, obturador de alta velocidade (até 1/4000 de segundo) podem ser encontradas cm câmeras profissionais, com um custo relativamente baixo em rclação às câmeras específicas para fotografia aérea.

Com o advento de câmeras digitais de alta resolução, a necessidade de filmes químicos de grande formato e alta sensibilidade vem se tornando cada vez menor. A capacidade de armazenamento de imagens digitais nessas câmeras, em relação ao seu tamanho, também tem aumentado bastante com o aparecimento de mídias densas para armazcnamento digital.

Em muitas aplicações de fotografia aérea, não se necessita de uma grande quantidade de recursos disponíveis para aplicação em equipamentos cspeciais, ou não se justifica um custo muito elevado para a obtenção das imagens. Alćm disso, muitas vezes essas aplicações não precisam da resolução e da qualidade oferecidus por equipamento específico. A utilização de câmeras convcncionais (convencionais de pequeno formato ou digitais) pode então se tornar uma alternativa bastante viável e interessante. 


\subsubsection{Fotografia Aérea com Aeronaves do Tipo Ultraleve}

Câmeras de pequeno formato têm sido usadas em UAVs (Unmanned Aerial Vehicles - Veículos Aéreos Não Tripulados) [Tri 00] [JOH 96] e mesmo em pipas [ABE 02]. Já foram feitos alguns estudos sobre o uso de aeronaves do tipo ultraleve como uma plataforma para fotografia aérea [GRA 86] [BAR 88]. Essa plataforma se mostra adequada para aplicações onde um equipamento compacto pode ser utilizado e quando não cxistem muitos recursos financeiro. O uso de equipamentos aerofotogramétricos convencionais normalmente não é possível nessas aeronaves, devido a limitações de tamanho.

Uma outra vantagem de aeronaves do tipo ultraleve, quando comparadas a acronaves de maior porte, é que clas necessitam de espaços menores para decolagem e pouso. Isso permite que scjam realizadas missões de fotografia aérea sobre áreas distantes de aeródromos convencionais, sem o inconveniente de voar o percurso de ida e volta até o local. $\Lambda$ ssim, é possível diminuir os gastos com rnamutenção e combustível. Os ultraleves podem ser levados até o local desmontados, transportados por meio de um automóvel, pick-up ou caminhão leve [GRA 86].

Em vários experimentos já realizados com o uso de ultraleves aplicados à fotografia aérea de pequeno formato foram obtidos bons resultados $\mathrm{em}$ baixas altitudes. Os ultraleves permitem vôos a baixa velocidade, possibilitando a obtenção de imagens livres de distorções atmosféricas e de distorçoes por movimento da imagem. Em contrapartida, as imagens geradas possuem menor escala, o que pode dificultiar o mapcamcnto de grandes áreas.

Foi notado nos experimentos que a qualidade do produto fotográfico gerado em tais missões depende, em grande parte, do desempenho e eficiência do piloto, já que os ultraleves são aeronaves básicas e não possuem uma grande quantidade de instrumentos. Deve-se notar também que a pilotagem desse tipo de aeronave é difícil na presença de ventos fortes.

Pode-se concluir que, para certos tipos de aplicações, incluindo missões de baixa altitude com cobertura de áreas relativamente pequenas, as acronaves do tipo uliraleve se mostranı como uma alternativa viável e de baixo custo. 


\subsection{GPS}

A idéia de se utilizar corpos celestes para navegação acompanha o homem desde os primórdios da humanidade. Ao que tudo indica, durante muito tempo, o homem continuará utilizando corpos celestes para se orientar. Nos dias atuais, entretanto, a orientação é feita com base em corpos dispostos convenientemente no espaço e sob seu inteiro controle.

Sistemas de navegação modernos que utilizam ondas de rádio possuem limitações: as ondas de rádio de alta freqüencia proporcionam navegação precisa, mas são influenciadas pelo relevo. As ondas de baixa freqü̂encia apresentam baixa precisão. Além disso, os equipamentos utilizados não são de fácil acesso para um usuário comum. Nas décadas de 60 e 70, o uso de satélites artificiais introduziu novos sistemas de navegação que resolveram alguns desses problemas. $O$ primeiro sistema norte-americano de navegação por satélites foi o Transit Navigation Satellites. Este sistema não obleve sucesso devido à baixa altitude e ao pequeno número de satélites, o que o tornava indisponível em alğuns pontos da Terra, em certos momentos. Fornecia a posição do veículo somente em duas dimensões, longitude e latitude.

O camiuho para uma solução mais ampla foi dado através de pesquisas realizadas nas décadas de 70 e 80 pela Força Aćrea dos Estados Unidos, que culminaram no desenvolvimento de um sistema de navegação por satélites denominado Navstar-GPS (Navstar Global Positioning System), também conhecido apenas como GPS. O GPS permite a qualquer usuário equipado com um receptor determinar sua posição na superfície da l'erra, a qualquer hora do dia e em qualquer lugar. Tal sistema está disponível para qualquer usuário civil ou militar, porén com restriçōes de precisão para determinadas classes de usuários.

Na subseção 2.4.1 é apresentado o princípio de funcionamento do GPS. A seção 2.4.2 descreve a estrutura e o mocanismo de interpretação dos sinais GPS. Os três segmentos ou partes do sistcma GPS são descritos na seção 2.4.3. Na seção 2.4 .4 são abordados aspectos de interface com receptores GPS para aquisição dos dados. Na seção 2.4 .5 é feita uma discussão sobre a precisão do sistema GPS. Finalmente, na seção 2.4.6 é apresentado o conceito de GPS diferencial (ou DGPS).

\subsubsection{Principio de Funcionamento do GPS}

Um receptor GPS na terra, no mar ou no ar captura os sinais de quatro ou mais satélites do sistema Navstar-GPS, simultaneamente ou seqüencialmente, para determinar suas coordenadas em três dimensôes: latitude, longitude e altitude. A figura 2.11 mostra como un receptor GPS típico encontra uma solução de navegação, usando os sinais de quatro satélites. Una cadeia de pulsos 
binários (0s e 1s) precisamente espaçados no tempo percorre o cspaço do primeiro satélite até o receptor próximo ao solo. Isso leva cerca de $1 / 11$ de segundo. O receptor então estima o tempo gasto pelo sinal para percorrer o trajeto subtraindo o tempo registrado em seu relógio interno do tempo de transmissão do satélite cxtraído do pulso recebido. O tempo do percurso do sinal é entrão multiplicado pela velocidade da luz para obter a distância estimada do satélite [LOG 92].

Se o relógio do receptor fosse perfeitamente sincronizado com os relógios a bordo dos satélites, três medições de distância como essa seriam suficientes para que o receptor determinasse a sua posição no espaço tridimensional. Porém, a maioria dos receptores de GPS utiliza osciladores de cristal de quartzo para medir o tempo. Esses osciladores de cristal não possuem uma sincronização perfeita com os relógios atômicos dos satélites GPS, que são muito mais estáveis e precisos.

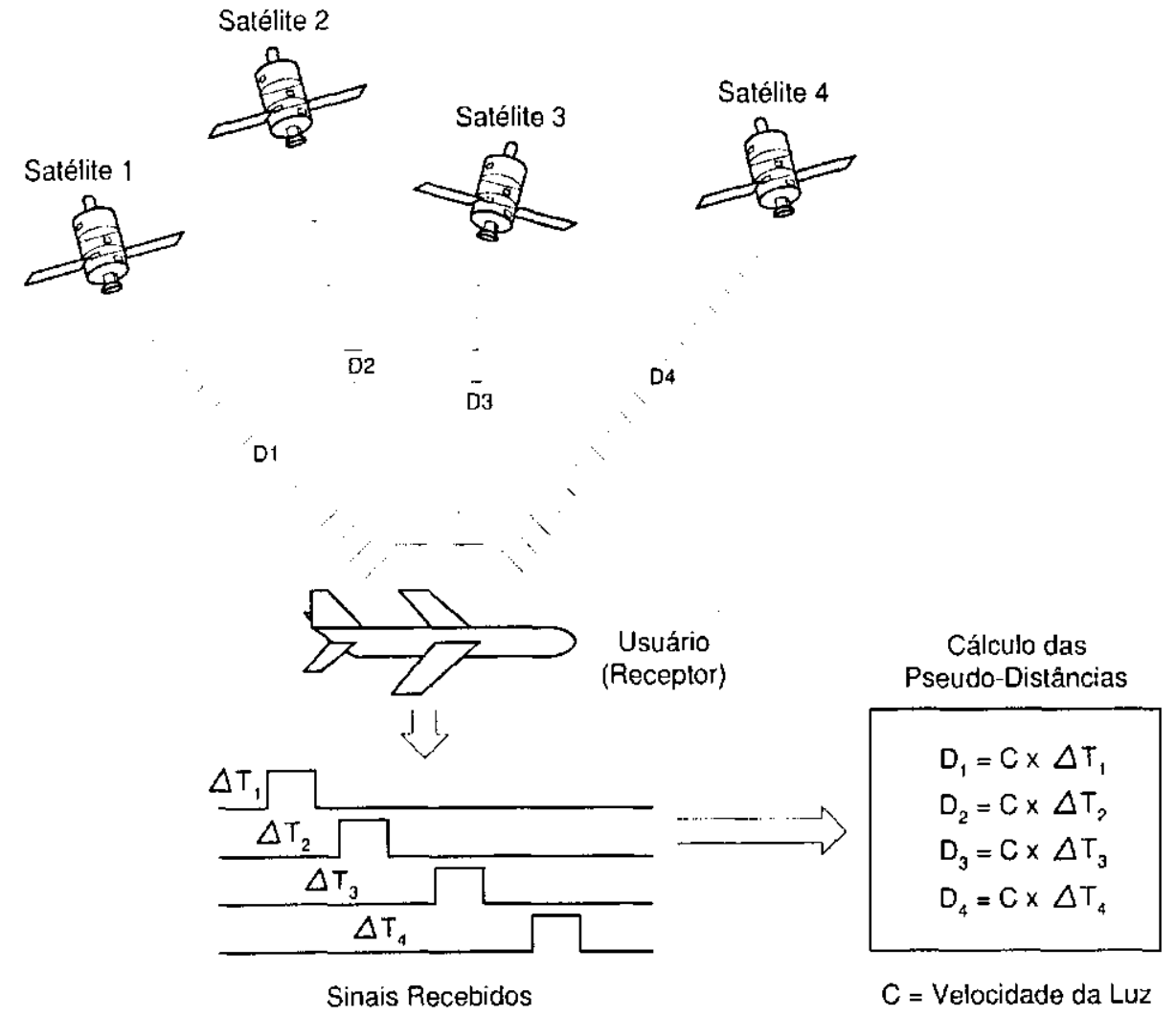

Figrura 2.11: Princípio básico de operação do GPS (adaptado de [LOG 92]).

Conseqüentemente, o receptor estima uma pscudo-distância de cada satélite. Todas as pseudo-distancias são afetadas pelo mesmo erro de tempo gerado pclo relógio do receptor. Assim, a laxa de orro E pode ser eliminada matematicamente, medindo-se as pseudo-distâncias de quatro satélites, em vez de apenas três. Isso gera um sistema de quatro equações com quatro incógnitas: 


$$
\begin{aligned}
& \left(X_{1}-U_{x}\right)^{2}+\left(Y_{1}-U_{y}\right)^{2}+\left(Z_{1}-U_{y}\right)^{2}=\left(D_{1}-E\right)^{2} \\
& \left(X_{2}-U_{x}\right)^{2}+\left(Y_{2}-U_{y}\right)^{2}+\left(Z_{2}-U_{y}\right)^{2}=\left(D_{2}-E\right)^{2} \\
& \left(X_{3}-U_{x}\right)^{2}+\left(Y_{3}-U_{y}\right)^{2}+\left(Z_{3}-U_{y}\right)^{2}=\left(D_{3}-E\right)^{2} \\
& \left(X_{4}-U_{x}\right)^{2}+\left(Y_{4}-U_{y}\right)^{2}+\left(Z_{4}-U_{y}\right)^{2}=\left(D_{4}-E\right)^{2}
\end{aligned}
$$

Três das incógnitas são as coordenadas do usuário, $U_{x}, U_{y} \mathrm{e} U_{\tilde{z}}$. A quarta incógnita ć o erro do relógio, E. Os valores $X_{i}, Y_{i}$ e $Z_{i}$ são as coordenadas do satélite $i$. As coordenadas de cada satélite são obtidas através das constantes de efemćride (clementos orbitais) codificadas no sinal transmitido. Essas constantes são utilizadas em cálculos algébricos e trigonométricos simples para determinar as coordcnadas $X_{i}, Y_{i}$ e $Z_{i}$ do satélite no momento em que o pulso foi transmitido.

É imprescindível que os tempos enviados por cada satélite GPS estejam perfeitamente sincronizados entre si. Devido à alta velocidade do sinal clctromagnético, um erro de apenas um bilionésimo de segundo na medição do tempo gera um erro de posicionamento de cerca de 30 centímetros. Para que os objelivos de sincronização do sistema GPS sejam atingidos, os satélites são equipados com relógios alômicos muito precisos. Esses relógios são tão estávcis que podem gerar um erro de apenas um segundo em 160.000 anos. Ainda assim, estações de controle terrestres são utilizadas para enviar dados de correção de tempo para os satélites pelo menos uma vez por dia [LOG 92].

\subsubsection{Estrutura dos Sinais GPS}

Cada satélite GPS transmite seus sinais nas mesmas duas freqüências: L1, de $1575,42 \mathrm{MHz}$, e L2, de 1227,60MHz. Dois códigos binários diferentes são transmitidos pelos satélites: o código C/A (Coarse Acquisition) e o código P (ou P-code - Precision Code). Esses dois códigos são sobrepostos na frequência $L 1$, enquanto que na frequência L2, apenas o código P é transmitido [LOG 92].

Para cada satélite há um código $\mathrm{C} / \mathrm{A}$ e um código $\mathrm{P}$ diferente. $\mathrm{O}$ código $\mathrm{C} / \mathrm{A}$ apresenta uma taxa de $1 \mathrm{MBit} / \mathrm{s}$ c é repetido a cada $1023 \mathrm{bits}$ (aproximadamente $1 \mathrm{~ms}$ ). O código P é transmitido a uma taxa de $10 \mathrm{MBits} / \mathrm{s}$ e repetido aproximadamente a cada $6 \times 10^{12}$ bits (aproximadamente sete dias). Esses códigos são chamados de pscudo-randômicos, pois a cadeia de sinais é aparentemente aleatória. Na realidade, esses códigos são gerados por relações matemáticas precisas, e são completamente previsíveis.

Um receptor GPS detecta o sinal de um satélite específico utilizando a técnica de acesso múltiplo por divisão de código (CDMA - Code Division Multiple Access). 1ntcrnamente, é gerada 
no receptor uma cadeia de pulsos idêntica à do salćlite que está sendo rastreado. Essa cadeia de pulsos é gradualmente deslocada no tempo até que esteja "casada"com a cadeia de pulsos erviada pelo salélite. Quando isso ocorre, a função de auto-correlação entre os sinais atinge um valor máximo. O tempo correspondente ao deslocamento realizado sobre o pulso gerado pelo receptor é então medido e utilizado no cálculo da pseudo-distância. O processo de aquisição do sinal C/A é ilustrado na figura 2.12 .

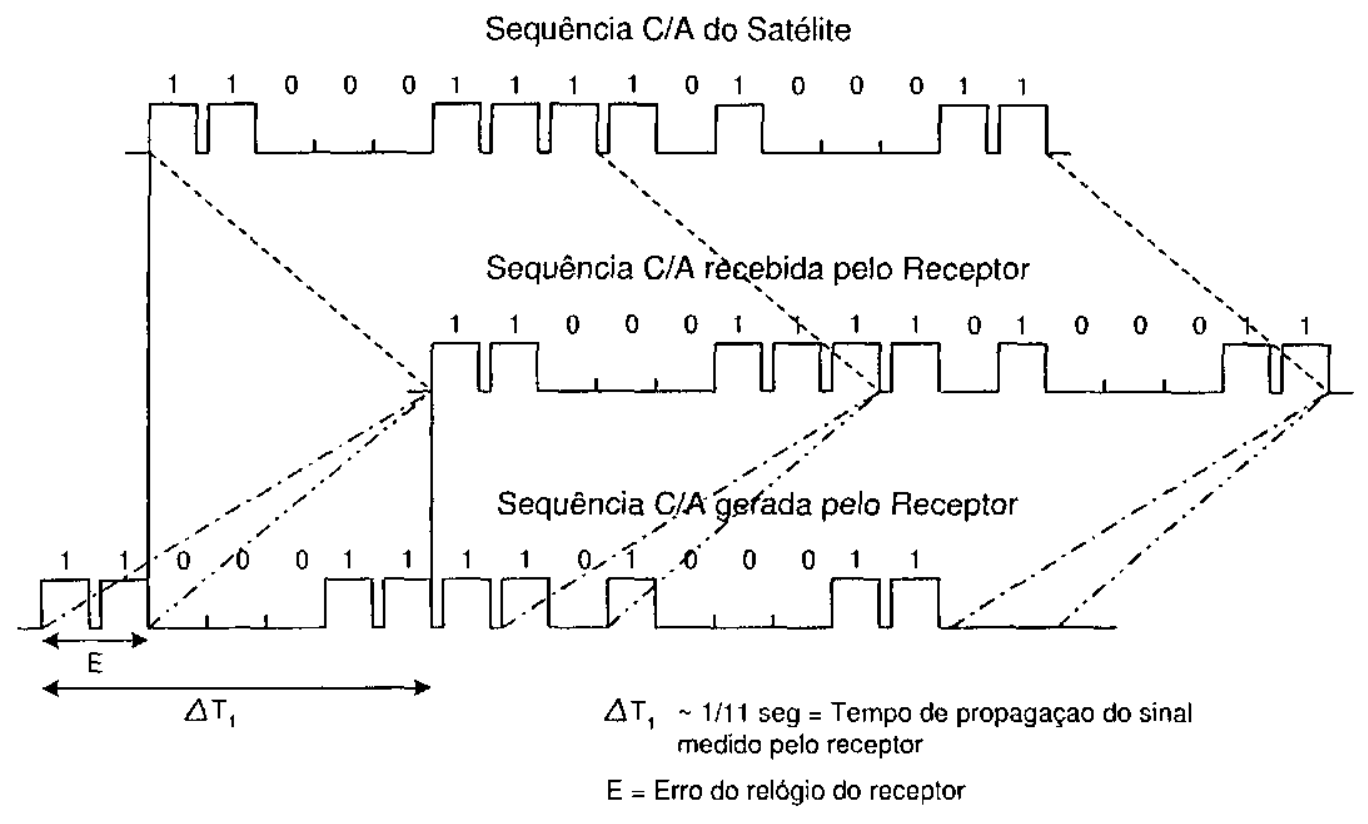

Figura 2.12: Aquisição do código C/A [KAP 96].

Uma cadeia de bits, com taxa de 50 bits por segundo, é sobreposta aos sinais C/A e P, utilizando adição $\mathrm{cm}$ módulo 2. Os dados contidos nessa cadeia de bits incluem [LOG 92]:

- Constantes de efeméride do satélite, definindo a sua órbita;

- Almanaque, descrevendo a posição de todos os satćlites GPS;

- Fatores de correção do relógio do satélite;

- Condições de operação do satélite.

$\mathrm{O}$ código $\mathrm{C} / \mathrm{A}$ está disponível a todos os usuários civis, enquanto que o código $\mathrm{P}$ é restrito apenas a usuários militares. Com o uso de um mecanismo denominado anti-spoofing, o código $\mathrm{P}$ ć cnviado de forma criptografada. Assim, apenas usuários autorizados podem ter acesso a um serviço de posicionamento mais preciso. Devido à sua mais alta taxa de transmissão, o código P permite menores erros na obtenção do tempo de propagação do sinal. Além disso, como o código 
$P$ é transmitido $\mathrm{em}$ ambas as freqüencias L1 e L2, o receptor pode usar os dados obtidos para eliminar erros causado pela refração ionosférica dos sinais [KAP 96].

\subsubsection{Segmentos do Navstar-GPS}

O Navstar-GPS pode ser dividido em três partes ou segmentos principais: espacial, de usuários e de controle.

\section{Segmento Espacial}

O segmento espacial consiste de 24 satélites distribuídos em seis planos orbitais igualmente espaçados, com quatro satélites em cada plano, e com uma altitude aproximada de $20.200 \mathrm{~km}$. Os planos orbitais são inclinados de 55 graus em relação ao Equador e o período orbital é de aproximadamente 12 horas siderais. Dessa forma, a posição dos satélites se repete, a cada dia, 4 minutos antes do que no dia anterior. Essa configuração garante que, no mínimo, quatro satélites GPS scjam visíveis em qualquer local da superfície terrestre, a qualquer hora [MON 00]. $\Lambda$ figura 2.13 ilustra a constelação dos satélites GPS.

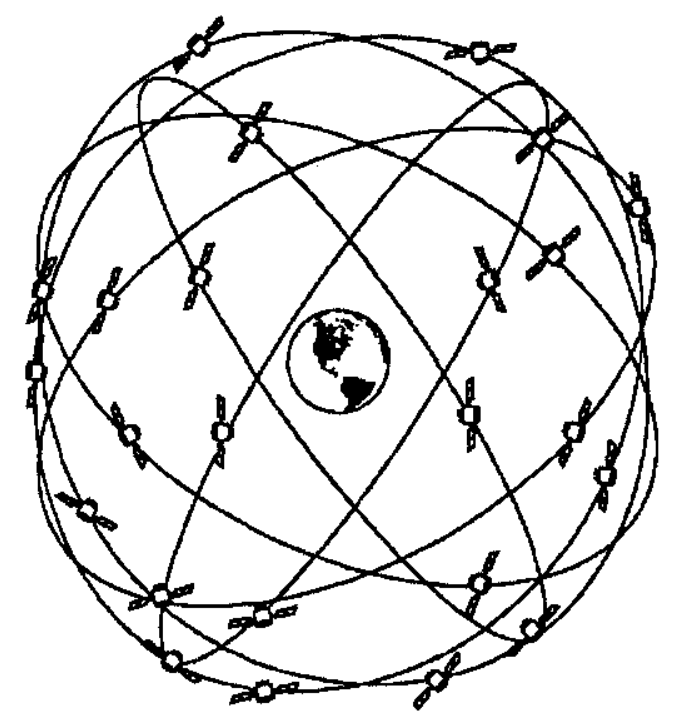

Figura. 2.13: Constelação dos satélites GPS [KAP 96].

\section{Segmento de Usuários}

O segmento de usuários é constituído pelos receptores GPS. O objetivo desse segmento é processar as informações de tempo e posição de quatro on mais satélites para a medição precisa de velocidade, posição e tempo [LOG 92]. 


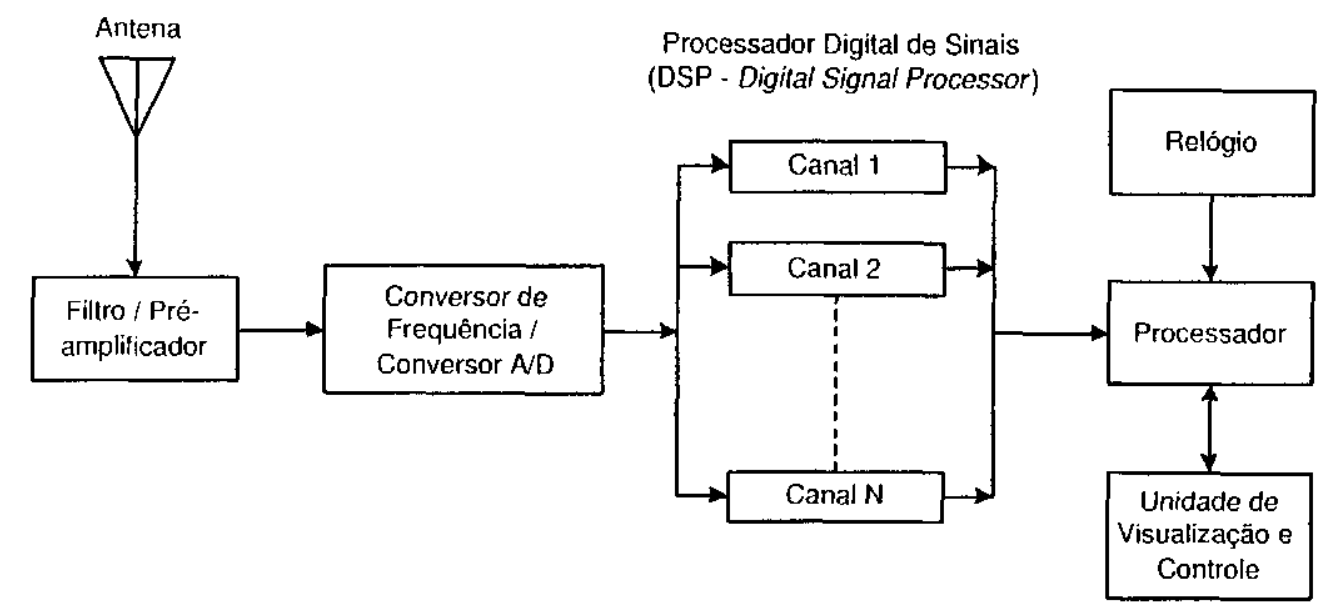

Figura 2.14: Diagrama de blocos simplificado de um receptor GPS [KAP 96].

A maior parte dos receptores possui canais separados, de forma que cada canal rastreia a transmissão de um único satélite. Um diagrama de blocos simplificado de um receptor GPS genérico ć apresentado na figura 2.14. Os sinais de rádio CDMA recebidos dos satélites geralmente passam por um filtro de modo a reduzir a interferência gerada por freqüências fora da banda desejada. Fsse filtro é normalmente seguido de um pré-amplificador. Em seguida os sinais são convertidos para uma freqüência intermediária, amostrados por um conversor analógico-digital e passados para $1 \mathrm{~m}$ processador digital de sinais (DSP - Digital Signal Processor). O DSP possui $N$ canais paralelos, sendo que cada um é responsável por extrair dados de navcgação dos sinais, incluindo pseudodistâncias, deslocamento Doppler e mensagens binárias codificadas no sinal (efemérides, almanaque, etc.). Um processador é utilizado para controlar a seqüência operacional do receptor e calcular a solução de navegação com base nos dados medidos pelo DSP. Uma unidade de visualização e controle ć responsável por exibir os dados para o usuário c captar dados de entrada. Um exemplo desse componente consiste de um display de cristal líquido acompanhado de um teclado simples [KAP 96].

Atualmente, há uma grande quantidade de receptores no mercado civil, para as mais diversas aplicações, muitas vezes integrados a outros dispositivos móveis como PDAs e notebooks.

\section{Segmento de Controle}

$\Lambda$ função do segmento de controle é rastrear e monitorar os satélites do sistema GPS, atualizando as constantes de suas efemórides e o crro de seus relógios. Esse segmento é composto por 5 estações de monitoramento no solo, sem operadores, mais uma estação-mestre de controle. As estações de monitoramento são analisadas por métodos de posicionamento independentes do sistema GPS para 
obtenção de suas coordenadas, e são equipadas com relógios atômicos muito precisos [LOG 92].

Quatro estações de monitoramento capturam sinais de um determinado satélite, ao mesmo tempo, calculando a que distâncias estão desse satélite. As pseudo-distâncias obtidas são transmitidas para a estação-mestre de controle. A estação-mestre processa as pseudo-distâncias obtidas pelas estações de monitoramento, para determinar as constantes orbitais e os fatores de correção nos relógios atômicos a bordo de cada satélite. Tais informações são atualizadas em cada satélite, uma vez ao dia, por antenas posicionadas ao redor da Terra.

A estação-mestre de controle é um computador operado pela Força Aérea dos Estados Unidos, situado no Consolidated Space Operations Center (CSOC). O CSOC, que também controla outros satélites militares, está localizado em uma área de segurança no Colorado [MON 00].

\subsubsection{Interface com Receptores GPS}

Muitos receptores GPS encontrados no mercado são voltados para o usuário final, possuindo dispositivos visuais, como tela de cristal líquido, para exibição dos dados de navegação. Entretanto, existem outros tipos de receptores direcionados para a integração de sistemas eletrônicos. Esses dispositivos possuem, geralmente, uma interface de comunicação serial padrão.

Os dados enviados pela maioria dos receptores GPS estão no formato padrão NMEA-0183 definido pela NMEA (National Marine Electronics Association). Os dados são enviados cm cadeias de caracteres no formato ASCII pré-definidas. Um excmplo de sentença gerada por um receptor GPS ć a seguinte:

\$GPGLL , $4250.5589, \mathrm{~S}, 14718.5084, \mathrm{E}, 092204.999, \mathrm{~A} * 2 \mathrm{D}$

A sentença consiste, basicamente, de cadeias de caracteres separadas por vírgulas. A primeira cadeia é uma palavra de controle, que indica quais os tipos de dados contidos na sentença. As demais cadcias contêm os dados propriamente ditos. As sentenças enviadas por cada modelo de reccptor GPS normalmente constam no manual de operação do receptor. A especificação completa de todos os tipos de sentenças pode ser obtida no documento de descrição do padrão NMEA-0183 vendido pela própria NMEA.

Alguns reccptores, principalmente os que possuem altas taxas de atualização da posição, possuem interfaces binárias próprias.

Independentemente do tipo de interface utilizada, os dados mais relevantes fornecidos pelos receptores GPS são:

- Posição (latitude, longitude e altitude); 
- Tempo;

- Velocidade (componentes X, Y e Z);

- Número de satélites utilizados;

- Dados dos satélites utilizados (posições, DOP, etc.)

\subsubsection{Precisão do Sistema GPS}

Existem vários fatores que influenciam na precisão de um receptor GPS, dentre eles:

- Disponibilidade seletiva

- Interferência ionosférica

- Geometria dos satélites

- Reflexão de sinais

Disponibilidade Seletiva (Selective Availability)

A disponibilidade seletiva foi um mecanismo utilizado pelo Departamento de Defesa dos Estados Unidos para degradar a precisão de receptores GPS de uso civil. Com a sua ativação, erros eram introduzidos nos sinais enviados pelos satćlites, de forma que apenas usuários autorizados pudessem eliminá-los nos receptores. A disponibilidade seletiva foi utilizada até o dia primeiro de maio de 2000. Desde cntão ela se encontra desativada.

\section{Interferência Ionosférica}

A ionosfera é uma camada da atmosfera da Terra que fica entre 80 e $400 \mathrm{Km}$ acima da superfície. Quando os sinais provenientes dos satélites atravessam a ionosfera, eles sofrem uma curvatura e um atraso. O tempo total de atraso é inversamentc proporcional ao quadrado da freqüencia de transmissão dos sinais. As duas freqüências de transmissão dos satélites (L1 c L2) podem ser utilizadas para realizar uma compensação no atraso. Cada frequiência resulta em um tempo de atraso diferente. Consęuïentemente, pode ser realizada uma simples correção matemática em um receptor de código $\mathrm{P}$ para extrair os atrasos ionosféricos. Já em receptores de código CA, que capturam somente sinais L1, não se pode utilizar esse método. Esses receptores modelam materraticamente o comportamento da ionosfera, usando um conjunto de cocficientes polinomiais 
que corrigem o erro provocado pela ionosfera em até $50 \%$, quando esses valores são comparados com aqueles näo-corrigidos.

\section{Geometria dos Satélites}

$\Lambda$ geometria dos satélites refere-se às posições dos satélites relativas ao posicionamento do usuário. A quantidade de erro introduzida pela geometria dos satélites é denominada DOP (Dilution of Precision). Existem vários componentes da DOP: vertical (VDOP), horizontal (HDOP), tempo (TDOP), posição (PDOP) e geometria (GDOP). Algumas posições de satélites garantem mais precisão. O receptor GPS calcula cada componente para cada combinação de quatro satélites c então utiliza os sinais provenientes dos quatro satélites que fornecem uma PDOP menor. Quanto maiores os valores numéricos dos fatores (PDOP, HDOP, VDOP, TDOP, GDOP), pior a precisão. Os valores para DOP que fornecem uma boa precisão variam entre 1 e 3. Quando o receptor calcula uma DOP maior que 6, ele nem tenta calcular a posição do ustrário [LOG 92].

\section{Reflexāo de Sinais}

Em condiçōes ideais, os sinais provenientes dos satélites seguem um único caminho, diretamente para o receptor GPS. Se o sinal é refletido por alguma barreira, pode-se ter mais de um caminho até o receptor, provocando un efeito de retardo do sinal. Os sinais chegam: dos satélites e de reflexões em objetos como uma montanha. Atralmente, somente receptores especiais, pesados e de custo alto podem detectar e eliminar os sinais refletidos. O receptor comum nâo consegue diferenciar os sinais diretos dos sinais refletidos. Se o receptor utilizar os sinais refletidos para determinar a posição, esta será errada.

\subsubsection{GPS Diferencial (DGPS)}

$\Lambda$ precisão fornecida por um sistema GPS não é satisfatória para alguns usuários civis, como pilotos de aviões e navios. A solução para uma melhor precisão é fornecida pelo sistema GPS diferencial (DGPS - Differential GPS) que garante uma precisão entre $2 \mathrm{~cm}$ e $15 \mathrm{~m}$.

O uso de DGl'S melhora a precisão de receptores GPS operando em modo convencional corrigindo crros comms a dois on mais receptores utilizando os mesmos satélites. Na forma mais básica de DGPS, um dos receptores utilizados é chamado de estação monitora (ou estação de referência), cuja posição é determinada com grande precisão, seja por métodos convencionais de posicionamento ou por meio de um receptor GPS mais preciso. Os demais receptores são os usuários do sistema (figura 2.15). A estação de referência calcula pscudo-distâncias como um receptor GPSS 
comum, mas como sua posição precisa ć conhecida, pode-se determinar os erros obtidos na medição da posição pelo GPS. Para aplicações de tempo real, a estação de referência transmite os valores desses erros para todos os usuários do sistema na área de cobertura. Para aplicações que não necessitam de dados corrigidos em tempo real, os erros podem ser armazenados na cstação de referência e pós-processados cm conjunto com as posições obtidas dos usuários.

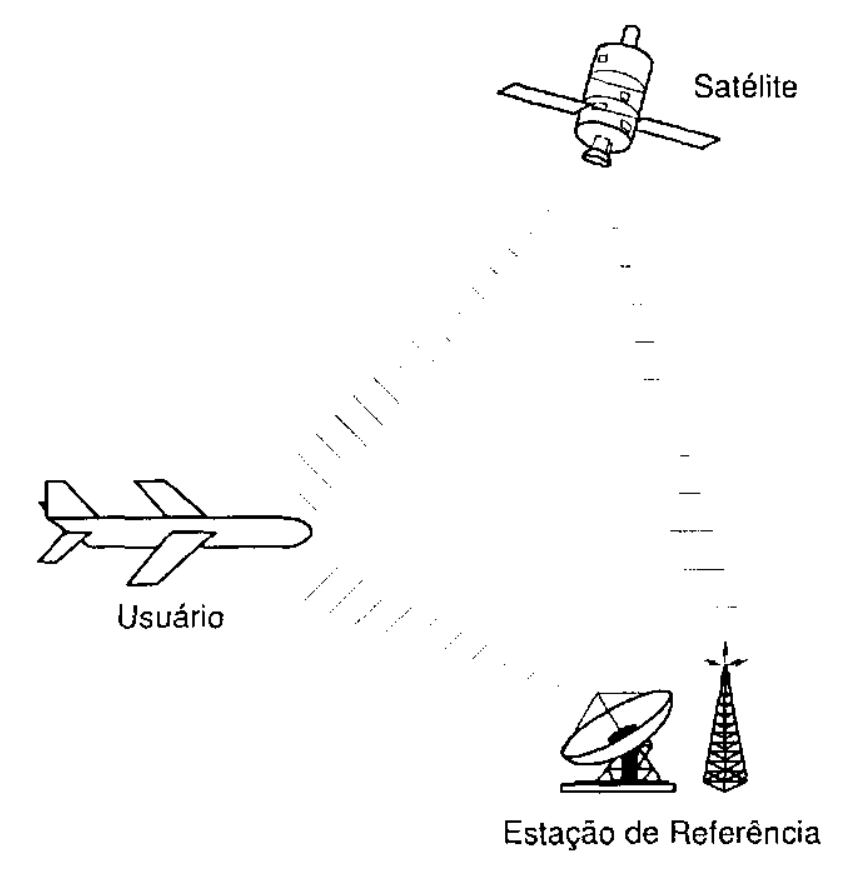

Figura 2.15: Sistema DGPS básico [KAP 96].

A precisão obtida por sistemas DGPS decorre do fato de que usuários em uma determinada área estão sujeitos aos mesmos erros de medição. Quanto maior a distância entre a estação de referência e os usuários, menos correlacionados estão os crros. Dessa forma, a utilização de DGPS é restrita a uma determinada área de abrangência. Caso seja necessária a utilização de DGPS em maiorcs áreas, faz-se necessária a utilização de mais de uma estação monitora [KAP 96]. 


\subsection{Georeferenciamento de Imagens Aéreas}

O principal objetivo de se obter imagens aércas no contexto deste trabalho ć a associação de dados da imagem a coordenadas geográficas. O objetivo desse processo é, geralmente, a geração de mapas temáticos ou topográficos de uma determinada região. Ao processo de associação de coordenadas geográficas a pontos da imagem damos o nome de georeferencimento.

O problema do georeferenciamento em imagens aéreas se ressume à obtenção de parâmetros de orientação externa da câmera fotográfica no momento da exposição. No total, são scis os parâmetros que se deseja obter: três de posição (X, Y e Z) e três de atilude (ângulos de rolagem, guinada e arfagem). Uma vez obtidos esses dados, a associação de coordenadas geográficas a pontos da imagem torna-se um problema trivial.

O georeferenciamento pode ser feito de várias formas e com diferentes níveis de precisão. Basicamente, existem duas abordagens para o processo de georeferenciamento: indireta e direta [CRA 00].

\subsubsection{Georeferenciamento Indireto}

A abordagem indireta de georeferenciamento (georeferenciamento indireto) é a mais comumente utilizada em sistemas de fotografia aérea. Essa abordagem é baseada em pontos de controle terrestre cujas coordenadas geográficas são conhecidas, e na medição das coordenadas correspondentes a esses pontos na imagem. Com essas medidas e o conhecimento da geometria interna da câmera, à oricntação externa pode ser estimada por um procedimento de ajustc [CRA 01].

Deve-se considerar que para aplicação de georeferenciamento baseado em pontos de controle terrestre, deve-se ter em mãos imagens nas quais scja possível identificar pontos específicos. Se a área fotografada é desprovida de pontos com características cspecíficas que possam ser notadas como uma floresta on uma região agrícola, pontos de controle devem ser colocados propositalmente no local antes do vôo.

Para sistemas atuais de fotografia aérea de pequeno formato ou de fotografia digital, o problema da associaçĩo de pontos de controle terrestres a pontos da imagem é ainda maior. Geralmente, nesse tipo de sistemas, a área de cobcrtura da imagern é pequena, gerando uma maior númoro de imagens, o que implica na necessidade de um maior número de pontos de controle. Esse número pode ser reduzido com o agrupamento de imagens lateralmente sobrepostas em blocos, utilizando métodos numéricos. Assim, os pontos de controle podem ser determinados para cada bloco, e não para cada imagem [WAR 96]. 


\subsubsection{Georeferenciamento Direto}

$\mathrm{Na}$ abordagem direta de georeferenciamento (georeferenciamento direto), os seis parâmetros de orientação externa da câmera são medidos diretamente por sensores acoplados a ela. Para isso, normalmente é utilizado um receptor GPS acoplado a uma unidade de medição inercial (UMI). O receptor GPS é responsável por fornecer os parâmetros de posição, enquanto que parâmetros de atitude c também de posição são fornecidos pela UMI.

Em sistemas que utilizam georeferenciamento direto, as funcionalidades do receptor GPS da unidade de medição inercial são complementares. Uma UMI é baseada na medição da velocidade angular de rotação em três eixos ortogonais, e da aceleração ao Jongo desses mesmos eixos. A aceleração pode ser integrada uma vez para se obter a velocidade e duas vezes para se obter a posição. A velocidade angular pode ser integrada uma vez para se obter a atitude. Todas essas medições são feitas a partir de um valor inicial. As integrações realizadas fazem com que os erros se acumulem ao longo do tempo. Para eliminar esses crros, uma alternativa é atualizar os valores iniciais com base em um outro dispositivo, como, por exemplo, um receptor GPS. Receptores GPS não fornecem dados a uma taxa muito alta, logo as medições de posição em curtos intervalos de tempo são feitas pela UMI. O receptor GPS é utilizado gcralmente apenas para reajustar os valores iniciais da UMI [BUR. 98] [CRA 00] [SKA 93].

O desenvolvimento de sistemas de georeferenciamento direto tem sido impulsionado em parte pelo desenvolvimento de scanners lineares para obtenção de dados cm plataformas aéreas. Para esses dispositivos, a uitilização de pontos de controle terrestres não se aplica, e a medição direta dos parâmetros de orientação externa é praticamente inevitável [CRA 99].

A precisão de sistemas de georeferenciamento direto depende diretamente da precisão do receptor GPS e da UMI utilizada. A ntilização de GPS diferencial, por exemplo, pode melhorar sigrificativamente os resultados desses sistemas.

Entre as vantagens do uso de georeferenciamento direto em relação a abordagens tradicionais pode-se citar:

- Uso em árcas de difícil identificação de pontos de controle

- Não há esforço de processamento (automático ou não) de pontos de controle nas imagens;

- Não há a necessidade de agrupamento de imagens em blocos. O uso de blocos de imagens pode ser indescjável em aplicações que cubram pequenas áreas ou em que se descje uma trajetória de vôo linear (como inspeção de linhas de transmissão de energia, por exemplo). 
A principal desvantiagem encontrada nesses sistemas é o alto custo de receptores GPS e UMIs quando se descja una alta precisão nas medições.

\subsubsection{Amostragem Aérea Pontual}

Uma das técnicas utilizadas para aquisição de dados de imagens aéreas é a amostragem aérca pontral ( $\mathrm{A} A \mathrm{P})$. Essa técnica não é baseada na cobertura fotográfica total da área pesquisada Para cada imagem, um ou mais índices pontuais são calculados, com base em dados extraídos da imagem. Por exemplo, pode-se segmentar a imagem obtida de modo a amostrar o número de determinados objetos no local.

$\Lambda$ resolução de amostragem pode ser variada com o número de imagens obtidas, e a proximidade entre elas. A técnica de amostragem aérea pontual pode ser interessante para missões com um grande número de imagens de grande escala, desde que obtidas com aeronaves de baixo custo de operação, como, por exemplo, ultraleves e pequenos veículos aéreos não tripulados.

Uma caractcrística importante dessa técnica é que não é necessário saber a atitude da aeronave durante a aquisição da imagem. Como os dados de uma imagem são tratados como amostras pontuais, apenas os parâmetros de posição são necessários. Dessa forma, apenas um receptor GPS pode ser acoplado à câmera para obter os dados de georeferenciamento [WAR 96]. 


\subsection{Considerações Finais}

Neste capítulo, foi feito $11 \mathrm{~m}$ estudo de conceitos básicos relacionados às ferramentas e equipamentos que devem ser utilizados na implementação do SciaGeo. O entendimento de princípios de fotografia em geral, fotografia aérea, posicionamento global e georeferenciamento é importante para a correta tomada de decisões durante a fase de desenvolvimento do SciaGeo. Foi possível, neste capítulo, analisar alguns aspectos que tornam este trabalho relevante, como a utilidade prática da fotografia aérea de pequeno formato e as vantagens no uso de aeronaves do tipo ultraleve como plataforma. Ainda foi possível notar a aplicabilidade da técnica de amostragem aérea pontual, que pode ser praticada com o auxílio do SciaGeo.

No próximo capítulo é apresentada uma análise de requisitos e uma especificação geral do SciaGeo, incluindo os requisitos funcionais e não funcionais do sistema, com diagramas gerais de hardware e software. 


\section{Capítulo 3}

\section{Análise de Requisitos e Especificação do SciaGeo}

\subsection{Introdução}

Para o projeto SciaGeo, foi fcita uma análise de requisitos para definir com clareza software e hardware a serem implementados. Neste capítulo são apresentados os requisitos definidos para a implementação do sistema, juntamente com diagramas de blocos e um diagrama de fluxo de dados geral do SciaGeo.

Inicialmente são descritos textualmente os requisitos do SciaGeo: na seçao 3.2 são aprescntados os requisitos funcionais e na seção 3.3 são aprescntados os requisitos não funcionais. $\mathrm{Na}$ seção 3.4 são apresentados diagramas de blocos para o hardware embarcado e o harduare utilizado para extração das imagens em solo, juntamente com uma explicação dos diagramas. Finalmente, na seção 3.5 é mostrado um diagrama de fluso de dados geral para o SciaGeo, com a respectiva explicação.

\subsection{Requisitos Funcionais}

A seguir são enumerados os requisitos funcionais do SciaGeo:

1. O SciaGeo deve ser um sistema capaz de capturar imagerıs aéreas e georeferenciá-las durante o vôo;

2. O sistema deve possuir harduare que possa ser embarcado cm acronaves da categoria ultraleve; 
3. O SciaGeo deve possuir uma interface com um operador que permita que ele dispare fotografias durante o vôo;

4. Posição, altitude c velocidade obtidas do receptor GPS devem ser armazenadas e relacionadas a carla fotografia, no instante em que são disparadas pelo operador;

5. Quadros de vídeo devem ser associados a dados de posicionamento do receptor GPS a uma taxa constante durante a missão;

6. O eixo ótico das câmeras deve ser mantido na direção vertical pelo piloto da aeronave durante o sobrevôo da área monitorada;

7. Deve existir softuare para extração de quadros de vídeo e coordenadas associadas às imagens capturadas em vôo;

8. O software de extração de quadros de vídeo deve gerar um arquivo de coordenadas em formato pré-definido e vários arquivos contendo as imagens correspondentes;

9. O software de extração de coordenadas das fotografias deve gerar um arquivo de coordenadas em formato pré-definido - as imagens devern ser obtidas manualmente da câmera fotográfica pelo usuário;

10. O sistema deve fornecer somente imagens e coordenadas em um padrão pré-definido. A interpretação e eventual conversão de dados para aplicação em um SIG deve ser feita pelo nsuário.

\subsection{Requisitos Não Funcionais}

A seguir são enumerados os requisitos não funcionais do SciaGeo:

1. O sistema deve ser modular, flexível e do baixo custo;

2. O sistema deve possuir um receptor GPS básico (com taxa de atualização de 1Hz) como sensor principal;

3. O sistema deve possuir uma câmera fotográfica (convencional ou digital) como sensor de imageamento de alta resolução e baixa taxa de amostragem;

4. O sistema deve possuir uma câmera filmadora (analógica ou digital) como sensor de imageamento de baixa resoluçẫo e alta taxa de anostragem; 
5. O sistema deve aceitar câmeras fotográficas e filmadoras de uso geral disponíveis para o consumidor comum, tendo cm vista o seu baixo custo e alta disponibilidade para compra.

\subsection{Diagramas de Blocos}

Nesta seção são apresentados diagramas de blocos básicos do hardware embarcado na aeronave e em solo. A figura 3.1 mostra o diagrama de blocos geral do hardware embarcado do SciaGeo.

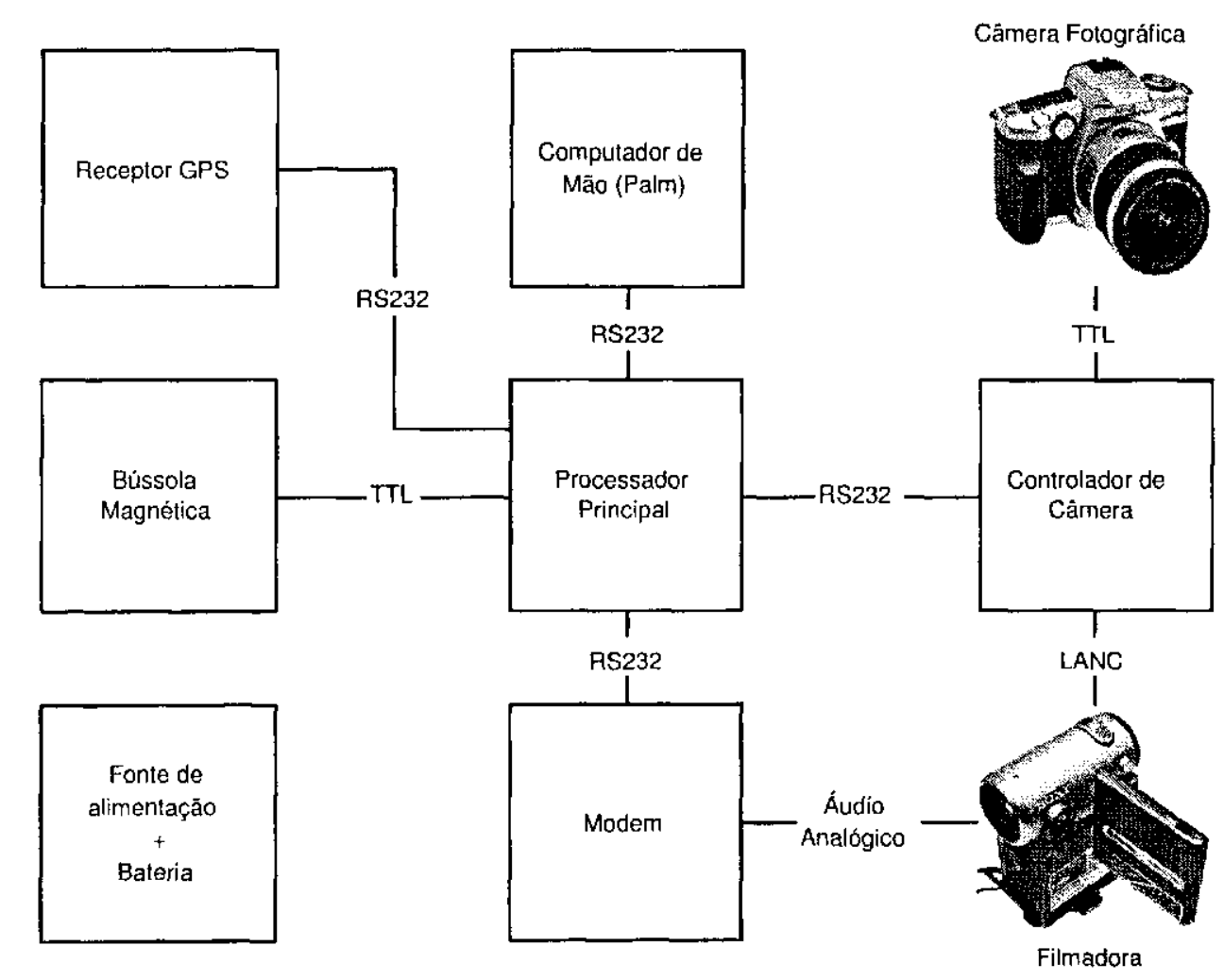

Figura 3.1: Diagrama de blocos do hardware embarcado na acronave.

O elemento central da arquitetura do hardware cmbarcado é o módulo do processador principal. Ele é responsável por integrar todas as partes do sistema, coordenando a troca de informaçōes entre elas. Em resumo, suas funções são:

- Reccber e interpretar dados de posição enviados pelo receptor GPS;

- Receber e interpretar dados da bússola magnética, além de efetuar rotinas de calibração sobre a mesma;

- Reccber comandos do usuário enviados pelo palmtop; 
- Processar dados de posição do GPS e codificá-los para gravação na trillıa de áudio da filmadora;

- Enviar comandos de acionamento das câmeras;

- Enviar dados de posição para registro das coordenadas das fotos no palmtop.

O palmlop funciona como um elemento de interação com o ustário, rodando uma interface gráfica capaz de receber comandos de acionamento das câmeras - iniciar gravação, parar gravação e disparar foto, por exemplo. Os comandos são codificados $\mathrm{em}$ um protocolo de comunicação serial para envio ao processador principal, usando um canal RS232.

A segunda função do palmtop no sistema é armazenar as coordenadas das fotografias. Opto11-se por armazenar as coordenadas no palmtop e não no processador principal pelo fato do o primeiro possuir boa quantidade de memória disponível, alćm de evitar a sobrecarga do processador principal. As coordenadas são codificadas em um protocolo serial pelo processador principal e cnviadas para o palmtop pelo canal RS232.

Ao processador principal estão acoplados sensores de posicionamento e de imageamento. Os sensores de posicionamento são um receptor GPS e uma bússola magnética. Scus dados são utilizados para georcferenciar os dados obtidos pelos sensores de imageamento. A interface com o receptor GPS é feita por um canal RS232 pelo qual são transmitidas as posições geográlicas em formato ASCII (protocolo NMEA). A interface com a bússola magnética é serial síncrona com sinais de controle adicionais.

Os sensores de imageantento acoplados ao processador principal são uma câmera fotográfica (convencional ou digital) e uma cânera filmadora. Para o controle das câmeras é utilizado um módulo com interface serial (controlador de câmera). A função desse módulo é receber dados de acionamento das câmeras enviados pelo processador principal e acionar as câmeras utilizando o padrão específico de cada uma delas. Para o acionamento da câmera filmadora, é utilizado um protocolo desenvolvido pela Sony, o LANC, disponível na maioria das filmadoras dessa marca. Para acionar a câmera fotográfica é utilizado um interface de disparo com relé, que pode ser utilizada na maioria das câmeras SLR profissionais e semi-profissionais.

$\Lambda$ s imagens da câmera de vírleo têm os dados de posicionamento codificados e armazcnados na trilha de áudio do filme. Assirn, a sincronização das coordenadas e dos quadros de vídeo é feita naturalmente. Os dados de posicionamento são empacotados c cnviados por um canal R.S232 para um modem de $2400 \mathrm{bps}$, onde são modulados para um sinal analógico que é gravado na trilha de áudio para posterior extração. 
O sistema embarcado é alimentado por uma bateria chumbo-ácida com capacidade de $7 \mathrm{AH}$, acoplada a uma fonte chaveada com tensão de saída de $5 \mathrm{~V}$.

A figura 3.2 mostra o diagrama de blocos geral do hardware de extração de dados utilizado em solo após o vôo.

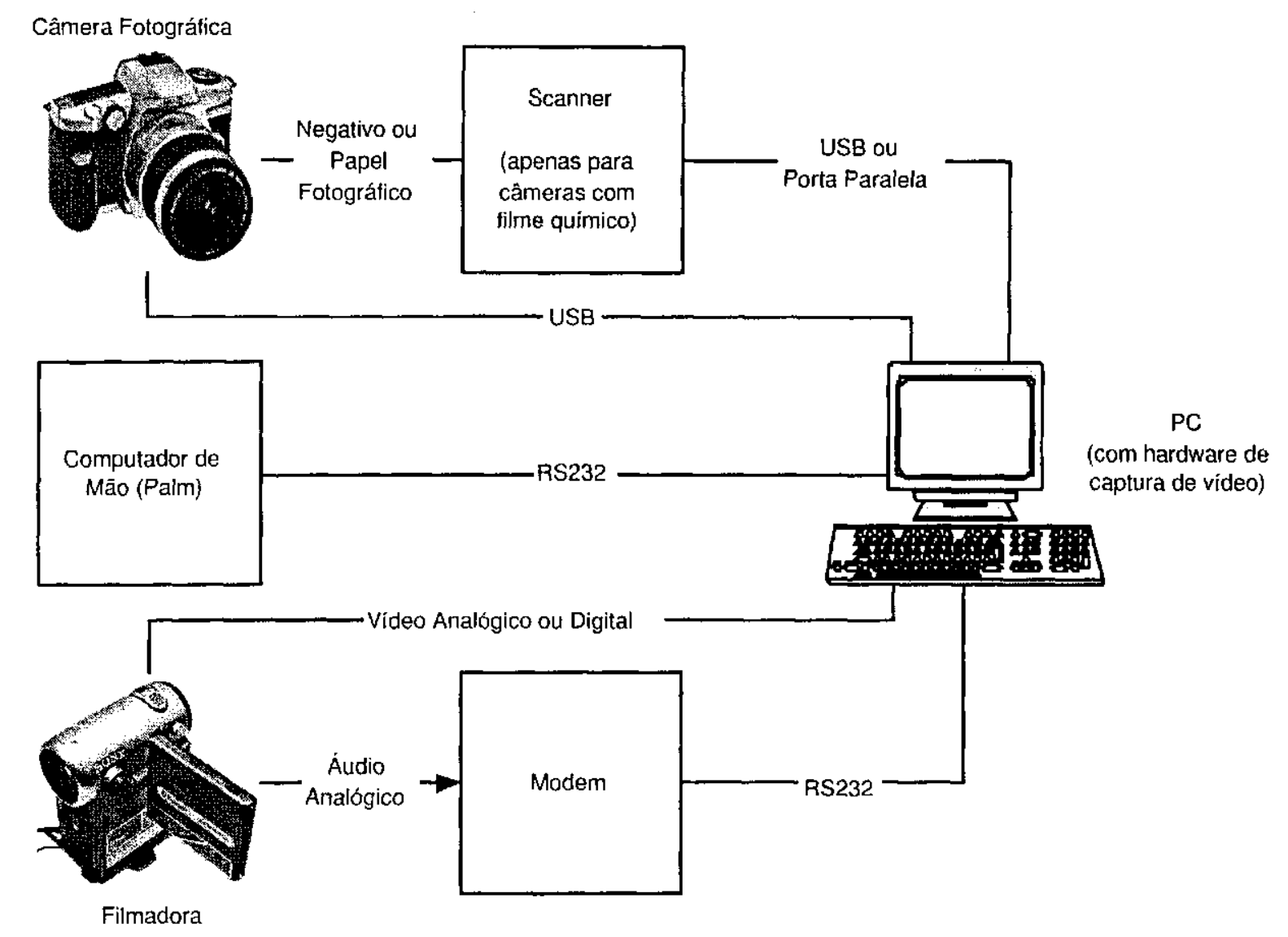

Figura 3.2: Diagrama de blocos do hardware de extração de dados em solo.

Os dados gravados no hardware embarcado durante o vôo devem ser extraídos, uma vez finalizado o vôo, para posterior processamento e integraçâo em um SIG. Os módulos que contém os dados são o palmtop, a câmera fotográfica e a filmadora. O componente onde os dados são reunidos é um computador convencional modelo IBM-PC.

As fotografias devem ser digitalizadas com o uso de um scanner caso a câmera fotográfica utilizada seja convencional. Se for usada uma câmera digital, esse clemento é eliminado do sistema, c os dados são enviados para o computador diretamente, utilizando geralmente uma interface USB.

Para as imagens da câmera fotográfica, as coordenladas são extraídas do palmtop por meio do canal RS232 do mesmo, utilizando software específico para isso no computador. 
Os quadros de vídeo da filmadora são transferidos diretamente para o computador por uma interface de captura de vídeo. As coordenadas gravadas na trilha de áudio são demoduladas para um sinal serial RS232 por um modem de 2400 bps, idêntico ao utilizado no hardware embarcado.

Dessa forma, é necessário que o computador utilizado possua as seguintes interfaces:

- Serial RS232, para comunicação com o palmtop e captura das coordenadas armazenadas na filmadora;

- USB ou paralela, para recuperação das fotografias;

- Captura de vídeo (analógico ou digital) compatível com a filmadora utlizada, para recuperação dos quadros de vídeo.

\subsection{Diagrama de Fluxo de Dados - DFD}

A figura 3.3 mostra o diagrama de fluxo de dados geral do software do SciaGeo. A metade superior do diagrama mostra o fluxo de dados do softurare embarcado. Esse fluxo pode ser dividido em duas frentes: a dos dados de posicionamento e a dos comandos do usuário.

As fontes dos dados de posicionamento são o receptor GPS e a bússola. Seus dados são processados pelo processador principal e armazenados nos dois destinos dos dados de posicionamento: a base de dados contida no palmtop e a trilha de áudio da filmadora.

No fluxo de comandos do usuário, a única fonte de dados é o próprio usuário. Seus dados são processados no palrntop, no processador principal e no controlador de câmera para serem enviados às câmeras. A integração entre o fluxo de comandos do usuário e o fluxo de dados de posicionamento é feita, no caso das fotografias, quando os comandos acionam o registro das coordenadas no momento do disparo.

A metade inferior do diagrama mostra o fluxo de dados do softuare de extração de dados executado em solo. Esse fluxo também pode ser dividido em duas partes: dados de vídeo e dados de fotografias. No fluxo de dados de vídeo, a filmadora é a fonte das imagens e a sua trilha de áudio é a fonte dos dados de posicionamento. No fluxo de dados de fotografias, as fontes são a câmera fotográfica, que contém as imagens, e o palmtop, que contém as respectivas coordenadas. $O$ processamento em ambos os fluxos de dados é feito no software de extração executado no computador.

O destino final dos dados do sistema é a base de imagens gerada pelo software do computador, contendo as imagens de baixa resolução (filmadoră) e de alta resolução (câmera fotográfica), associadas às respectivas coordenadas. 


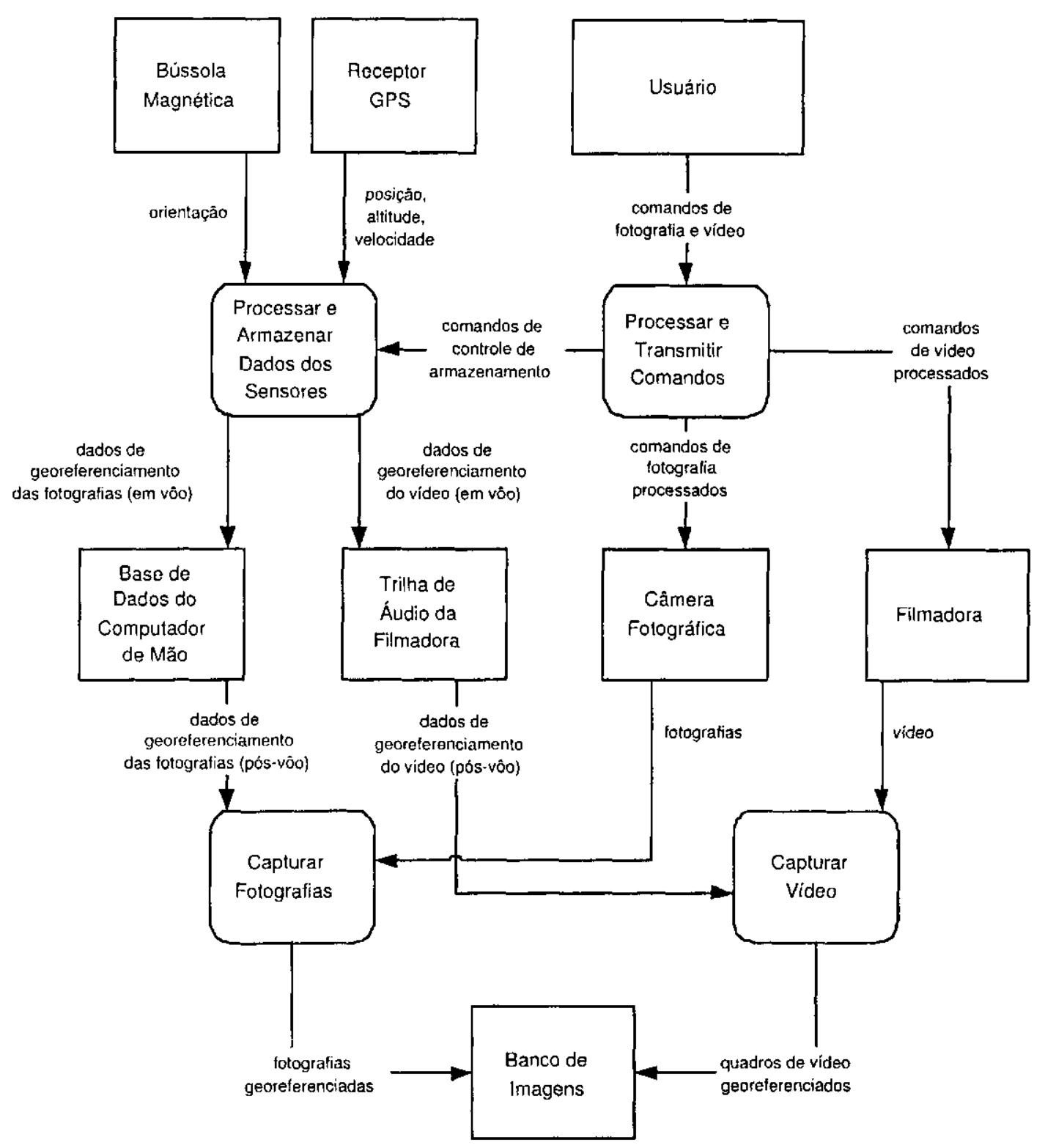

Figura 3.3: Diagrama de fluxo de dados do sistema como um todo.

\subsection{Considerações Finais}

Nesta seção foi apresentada uma análise de requisitos e um projeto prcliminar de harduare e software do SciaGeo. Esses dados são utilizados nos capítulos 4 e 5 para a elaboração de um projeto detalhado e integração dos componentes de hardware e software, influenciando tambóm nas decisões pontuais tomadas durante a implementação do sistema.

No próximo capítulo é apresentado o detalhamento do projeto de hardware e aspectos de sua implementação. 


\section{Capítulo 4}

\section{Projeto e Implementação}

\section{Hardware}

\subsection{Introdução}

Uma particularidade deste trabalho de mestrado foi a necessidade de desenvolver um conjunto de hardware específico para o sistema. A integração entre software e hardware foi um requisito básico para o sucesso do trabalho. Alguns dispositivos hardware utilizados já estão disponíveis no mercado, como:

- Processador principal Rabbit;

- Câmera fotográfica;

- Filmadora;

- Receptor GPS;

- Palmtop.

O trabalho excrcido sobre esses dispositivos esteve relacionado à sua interconexão $\mathrm{c}$ integração no contexto do sistema desenvolvido.

Porém, certas funcionalidades do sistema são muito específicas, e criaram a necessidade de desenvolvimento de circuitos eletrônicos cspecíficos para as tarefas envolvidas. Algumas dessas funcionalidades já estavam presentes no Projeto ARARA, que vem sendo descrivolvido no Laboratório de Computação de Alto Desempenho do ICMC-USP. Dessa forma, alguns módulos de hardware foram desenvolvidos e utilizados em conjunto com o Projeto ARARA - são eles: 
- Módulo controlador de câmera;

- Conversor de níveis lógicos RS232/TTL;

- Fonte de alimentação chaveada de $5 \mathrm{~V}$.

O único módulo de hardware desenvolvido exclusivamente para o SciaGeo foi o modem de 2400bps utilizado para modulação e demodulação de sinais digitais no canal de áudio analógico da filmadora.

Na seção 4.2 é apresentada uma descrição das interfaces de hardware utilizadas na interconexão dos equipamentos, juntamente com justificativas para o seu uso. A seção 4.3 descreve os fatores que pautaram a seleção de dispositivos e componentes para a implementação do SciaGco. Na seção 4.4 são abordados os aspectos rclevantes na scleção dos módulos de hardware adquiridos para integração ao sistema. Na seção 1.5 são descritos com detalhes os módulos desenvolvidos no contexto deste trabalho e os fatores que direcionaram as decisões no seu projeto.

\section{$4.2 \quad$ Interfaces}

A comunicação entre o processador principal e os demais módulos do SciaGco foram feitas utilizandose interfaces padrão RS232, com níveis lógicos diferenciados em diversas partes do sistema, sendo eles padrão RS232 ou TTL. A utilização desse tipo de interface foi sclecionada pelos seguintes fatores:

- Alta versatilidade;

- Diferentes velocidades de comunicação;

- Utilizada por muitos equipamentos no mercado;

- Disponível em vários modelos de processadores;

- Satisfaz todos os requisitos de comunicação do sistema.

As interfaces previstas para comunicação com as câmeras foram duas:

- Linha única para disparo de fotografia por relé;

- Canal serial RS232;

- Canal de comunicação com o protocolo LANC. 
O linha de disparo da câmera fotográfica por chave ou relé é o meio até hoje mais utilizado pela maioria das câmeras fotográficas profissionais ou semi-profissionais, sejam elas digitais ou convencionais. Uma desvantagem dessa interface ć a ausência de confirmação de disparo, podendo levar à perda de sincronização entre as coordenadas registradas e as imagens, no caso de um disparo não ter sido efetivamente rcalizado após o acionamento da chave. Essa interface foi desenvolvida para que o sistema pudesse aceitar uma maior gama de modelos de câmeras fotográficas.

Um canal serial RS232 é utilizado por algumas câmeras no mercado, por isso ele também está previsto no projeto. Sua utilização elimina o uso do módulo controlador de câmera, uma vez que a comunicação pode ser feita diretamente com o processador principal.

O protocolo LANC foi implementado por ser um dos poucos padrões de comunicação com câmeras filmadoras, utilizado por aparelhos da marca Sony, marca bastante difundida no mercado de filmadoras. A implementação dessa interface permite a operação da filmadora à distância, facilitando em alguns casos a operação do sistema, permitindo um maior controle do uso da fita de vídeo durante o vôo. Isso possibilita a exccução de missões mais longas, filmando apenas algumas regiões de intcresse.

\subsection{Seleção de Dispositivos para Implementação}

Uma importante consideração a ser feita quanto à seleção dos dispositivos é que foi levada em consideração a disponibilidade desses equipamentos para uso no contexto desse trabalho. Apesar desse fato, os equipamentos foram selecionados satisfazendo os critérios julgados necesários para atender os requisitos do SciaGeo da melhor forma possível. Esses critérios são apresentiados nas subseções seguintes.

\subsubsection{Processador Principal}

O processador principal do sistema selecionado foi o modelo Rabbit 2000, fabricado pela Rabbit Semiconductor. O Rabbit 2000 é um processador de 8 bits que é comercializado pelo fabricante isoladamente ou em módulos contendo memória flash e SRAM, além de circuitos básicos para operação do processador, como de geração de $c l o c k$, por exemplo.

No SciaGeo foi utilizado o módılo RCM2300 comercializado pela Rabbit Semiconductor Nesse módulo, o processador opera a uma velocidade de $22.1 \mathrm{MHz}$. A memória disponível no módulo é de 256 e 128 kilobytes dos tipos flash e SRAM, respectivamente. O módulo possui 29 pinos de I/O, e disponibiliza 4 portas seriais assíncronas com níveis TTL. A tensão de alimentação do módulo é 
de $5 \mathrm{~V}$, e o consumo nominal é de $108 \mathrm{~mA}$.

$\Lambda$ escolha do RCM2300 para utilização como processador principal no SciaGeo se deu pelos seguintes fatores:

- Baixo custo;

- Boa quantidade de portas seriais;

- Boas ferramcntas de desenvolvimento;

- Fácil integração do circuito no sistema;

- Desempenho atendendo os requisitos do SciaGeo.

\subsubsection{Câmera Fotográfica}

O SciaGeo foi projctado de forma a accitar diferentes tipos de câmeras fotográficas. A categoria de câmeras fotográficas na qual o projeto foi focado foi a de câmeras profissionais e semi-profissionais de uso geral, particularmente as SLR (Single Lens Reflex), tanto convencionais quanto digitais. A opção por essa categoria de câmcras se deu pelos seguintes fatores:

- Baixo custo em relação a câmeras específicas para fotografia aérea;

- Melhor desempenho e qualidade de imagem em relação a câmeras de uso geral de outras categorias;

- Tecnologia avançando rapidancnte, principalmente em câmeras digitais SLR;

- Boa relação entre o custo da câmera e a qualidade das imagens obtidas.

O modelo utilizado durante os testes foi um modelo Maxxum 5, fabricado pela Minolta. Essa é uma câmera SLR convencional profissional e foi utilizada devido a disponibilidade imediata para uso no projeto. O uso de uma câmera SLR digital seria desejável, mas não havia disponibilidade durante o desenvolvimento, em particular de modclos com resolução comparável à do modelo Maxxum 5 .

\subsubsection{Filmadora}

O SciaGeo foi desenvolvido com o objetivo de ser utilizado com câmeras filmadoras convencionais compactas disponíveis no mercado (camcorders). De forma mais abrangente, qualquer equipamonto, analógico ou digital, que capture dados de vídeo e áudio pode ser acoplado ao SciaGeo. As 
filmadoras compactas apresentam uma facilidade de integração devido ao seu tamanho, e também apresentam uma boa qualidade de imagem no caso das filmadoras digitais (MiniDV, por exemplo). Adicionalmente, as filmadoras fabricadas pela Sony podem ser operadas de forma mais fácil com o uso do barramento LANC, conforme citado na seção 4.3 .

A filmadora utilizada nos testes foi um modelo Sony PC110 digital MiniDV. Esse equipamento foi utilizado por estar disponível para utilização no projeto junto à Embrapa

\subsubsection{Receptor GPS}

O desenvolvimento do SciaGeo foi voltado para o uso de receptores GPS de baixo custo, particularmente os que possuem taxa de atualização de $1 \mathrm{~Hz}$. A utilização de receptores de maior taxa de atualização é possível, e melhora a precisão de georeferenciamento, porém esses receptores normalmente apresentam um custo muito alto.

O reccptor GPS é mais um item que pode ser trocado do sistema sem alterações no software e com poucas ou nenhuma alteração no hardware. A comunicação com o SciaGeo é feita por meio de um protocolo bem conhecido (sentenças NMEA) e utilizado por virtualmente todos os receptores GPS do mercado. Assim, a troca dessc dispositivo depende apenas de fiação e conectorização do novo receptor.

O reccptor GPS utilizado nos testes foi um modelo Garmin GPS35, com precisão aproximada de $15 \mathrm{~m}$ e taxa de atualização de $1 \mathrm{~Hz}$. Fsse modelo foi utilizado nos testes por estar disponível junto ao Projeto ARARA.

\subsubsection{Palmtop}

O palmtop selecionado para uso no SciaGeo foi o Palm Vx, com memória de $8 \mathrm{Mb}$, fabricado pela Palm Inc.. O software pode ser executado também em outros modelos que operem com o sistema operacional PalmOS, que satisfaçam os requisitos de armazenamento de memória e possuam um canal de comunicação serial para comunicação com o SciaGco. $\Lambda$ escolha de modelos baseados no sistema operacional PalmOS se deu pelos seguintes fatores:

- Boa disponibilidade no mercado, notadamente no mercado nacional;

- Baixo custo se comparado a palmtops baseados ern outros sistemas operacionais;

- Atendem às necessidades do SciaGeo com um custo baixo. 


\subsection{Descrição Detalhada do Hardware Desenvolvido}

Nesta seção é apresentada uma descrição funcional dos módulos de hardware desenvolvidos no âmbito deste trabalho:

- Módulo controlador de câmera;

- Conversor de níveis lógicos RS232/TTL;

- Fonte de alimentação chaveada de $5 \mathrm{~V}$;

- Modem de 2400bps.

Além da descrição funcional, são apresentados os fatores que pautaram as decisões de projeto no desenvolvimento dos módulos. Como complemento à descrição contida nesta seção, no Apêndice A são apresentados os diagramas esquemáticos dos módulos citados.

\subsubsection{Módulo Controlador de Câmera}

O módulo controlador de câmera é responsável por processar os comandos de disparo enviados pelo processador principal, acionando as câmcras no momento adequado. No caso da câmera fotográfica, o acionamento é feito por meio de um relé. Para a filmadora, os comandos são enviados pelo barramento LANC.

O módulo consiste de um microcontrolador fabricado pela Microchip Inc., integrante da família PICMicro, modelo PIC16F628. Esse é um microcontrolador de 8 bits, com tecnologia RISC, e opera com uma frequência de clock de até $20 \mathrm{MHz}$. Os controladores da família PICMicro utilizam uma organização de memória do tipo Harvard, com instruções e dados armazenados em espaços de endereçamento de memória diferentes. O modelo PIC16F628 possui, integrados no chip, memória de programa flash com capacidade para 2048 instruções, memória de dados SRAM com capacidade de 224 bytes e memória de dados EEPROM com capacidade para 128 bytes.

Além dos componentes básicos de um microcontrolador, o PIC16F628 possui, entrc outros, os seguintes recursos:

- 3 timers ( 2 de 8 bits e 1 de 16 bits);

- 1 porta serial universal (síncrona/assíncrona);

- Walchdog timer;

- 2 comparadores analógicos; 
- Capacidade para programação in-circuit;

- Um pino de saída com coletor aberto.

A família PICMicro foi selecionada para utilização no módulo controlador de câmera pelos seguintes motivos:

- Possui como periférico uma porta serial implementada por hardware;

- Alta velocidade;

- Alta disponibilidade;

- Boas ferramentas de desenvolvimento de software e de gravação do chip;

- Fácil programação em linguagem assembly com instruções RISC;

- Possui um pino de saída com coletor aberto para uso no barramento LANC.

A porta serial do microcontrolador é conectada ao processador principal e o relé de disparo da câmera contido na placa de circuito impresso é conectado ao soquete de disparo da câmera. O pino de coletor aberto do microcontrolador é conectado ao barramento LANC da câmera fotográfica. A placa ainda possui saídas adicionais para acionar a fonte de alimentação das câmeras.

\subsubsection{Conversor de Níveis Lógicos RS232/TTL}

O conversor de níveis lógicos é utilizado para condicionar os sinais seriais utilizados pelos diferentes subsistemas do SciaGeo. Equipamentos como o receptor GPS e a câmera fotográfica utilizam níveis lógicos no padrão RS232, enquanto que os processadores utilizados trabalham com sinais scriais com niveis TTL.

O conversor possui dois canais e é inserido na linha de comunicação serial entre os componentes cm questão. A conversão dos níveis lógicos é feita por um circuito integrado MAX232, fabricado pela Maxim-IC, inserido na placa de circuito impresso.

\subsubsection{Fonte de Alimentação}

O circuito é alimentado externamente por uma bateria chumbo-ácida selada de $12 \mathrm{~V}$ com capacidade nominal de 7Ah. A tensão gcrada por essa bateria é regulada por uma fonte chaveada, com tensāo de saída de $5 \mathrm{~V}$, que é utilizada para alimentar todo o hardware do SciaGeo, com exceção do receptor GPS, que possui uma entrada de alimentação de 12V. 


\subsubsection{Modem de 2400bps}

Como mencionado na seção 4.2, os dados de georeferenciamento dos quadros de vídeo são gravados no canal de áudio da fita de vídeo. As coordenadas são representadas em formato digital, e precisam ser moduladas em um sinal analógico que possa ser gravado na trilha de áudio.

Para modular e demodular os dados de georeferenciamento, foi desenvolvido um modem simples de 2400bps. Essa taxa se mostrou suficiente para armazenar os dados de georeferenciamento com uma frequência de $2 \mathrm{H} z$ na trilha de áudio. O método utilizado ć o de frequência modulada (FM). O circuito integrado que realiza a modulação e demodulação do sinal é o modelo MX614 fabricado pela MX-COM.

A placa do modem ainda possui ajustes de amplitude da portadora. É necessário fazer esese ajuste para cada modelo diferente de filmadora utilizado, utilizando um osciloscópio, para que os picos e vales da forma de onda da portadora não sejam distorcidos pela filmadora.

\subsection{Testes}

Os testes realizados para validação do hardware podem ser classificados em duas calegorias:

- Testes modulares

- Testes de integração

Os testes modulares foram realizados com o objetivo de validar os módulos individualmente, com o uso de softurare auxiliar (tanto externo quanto interno ao módulo) desenvolvido especificamente para isso. Nessa etapa foram utilizados também equipamentos eletrônicos de medição convencionais, como multímetro e osciloscópio. Nessa etapa também foram realizados eventuais ajustes e/ou calibrações de hardware nos módulos testados. Os testes consistiram em estimular as entradas dos subsistemas, avaliando por meio de medições a saída gerada.

Após os módulos terem sido testados individualmente, foi iniciada uma etapa de testes de integração, onde todos os módulos foram interconectados e seu funcionamento conjunto foi testado, juntamente com a funcionalidade do software final.

\subsection{Montagem}

As últimas etapas no desenvolvimento do hardware foram a montagem dos módulos em um encapsulamento comum e a interconexão entre os módulos, incluindo fiação e conectorização. A figura 4.1 mostra a distribuição física dos componentes do sistema. 


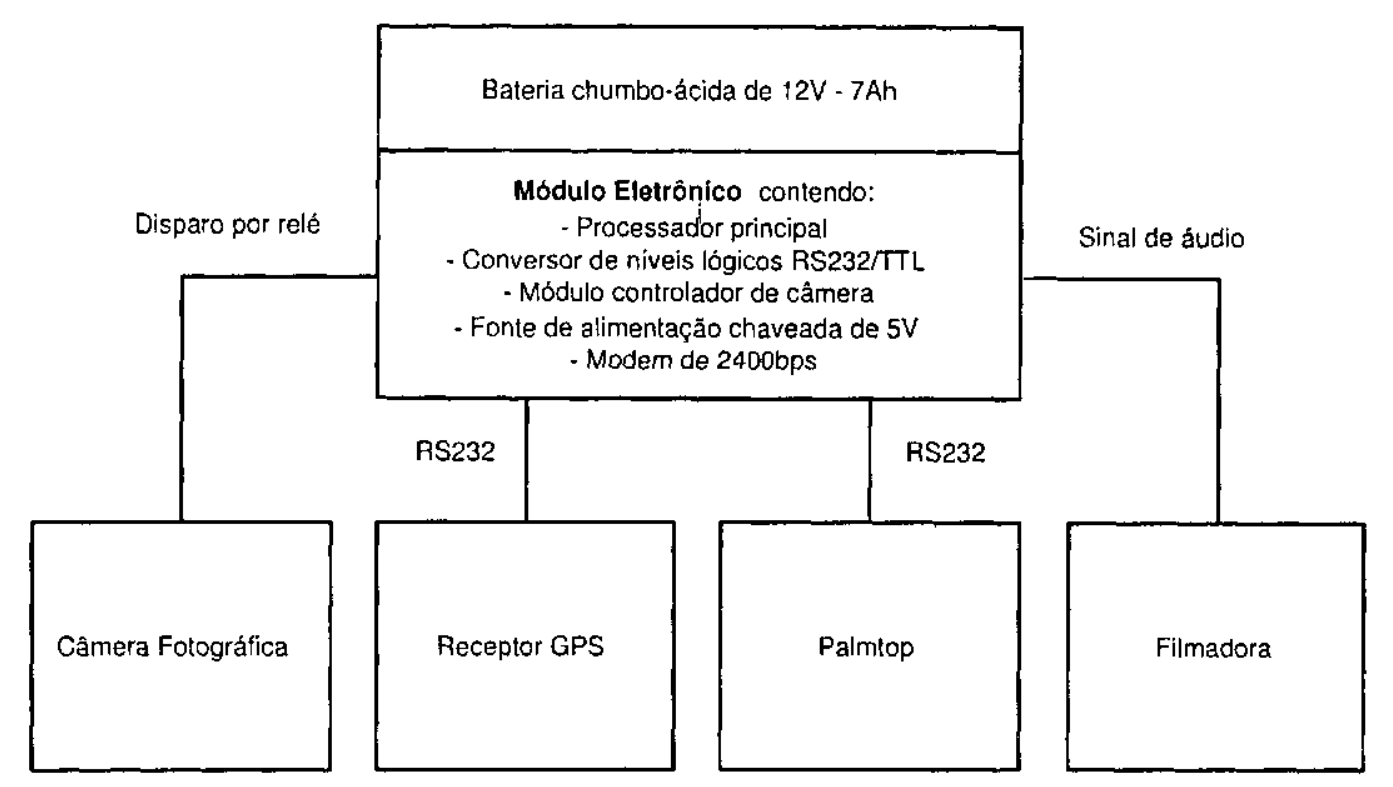

Figura 4.1: Distribuição física dos componentes do sistema.

Um único encapsulamento mecânico foi utilizado para agrupar as placas eletrônicas desenvolvidas. Esse encapsulamento foi denominado "módulo eletrônico". A figura 4.2 mostra o detalhe do resultado da integração e montagem mecânica do módulo eletrônico do SciaGco.

\subsection{Considerações Finais}

Neste capítulo foi apresentada a scquência de desenvolvimento do hardware do SciaGeo, desde o projeto até a montagem final. Foram abordados ainda as interfaces de hardware utilizadas, a seleção de equipamento, o desenvolvimento de módulos específicos e a metodologia de testes utilizada para validação dos subsistemas e do sistema integrado.

No quinto capítulo são descritos o projeto e a implementação dos módulos de software do SciaGeo. São apresentadas descrições textuais e diagramas de fluxo de dados dos módulos, bem como aspectos das interfaces de comunicação e metodologia de testes. 


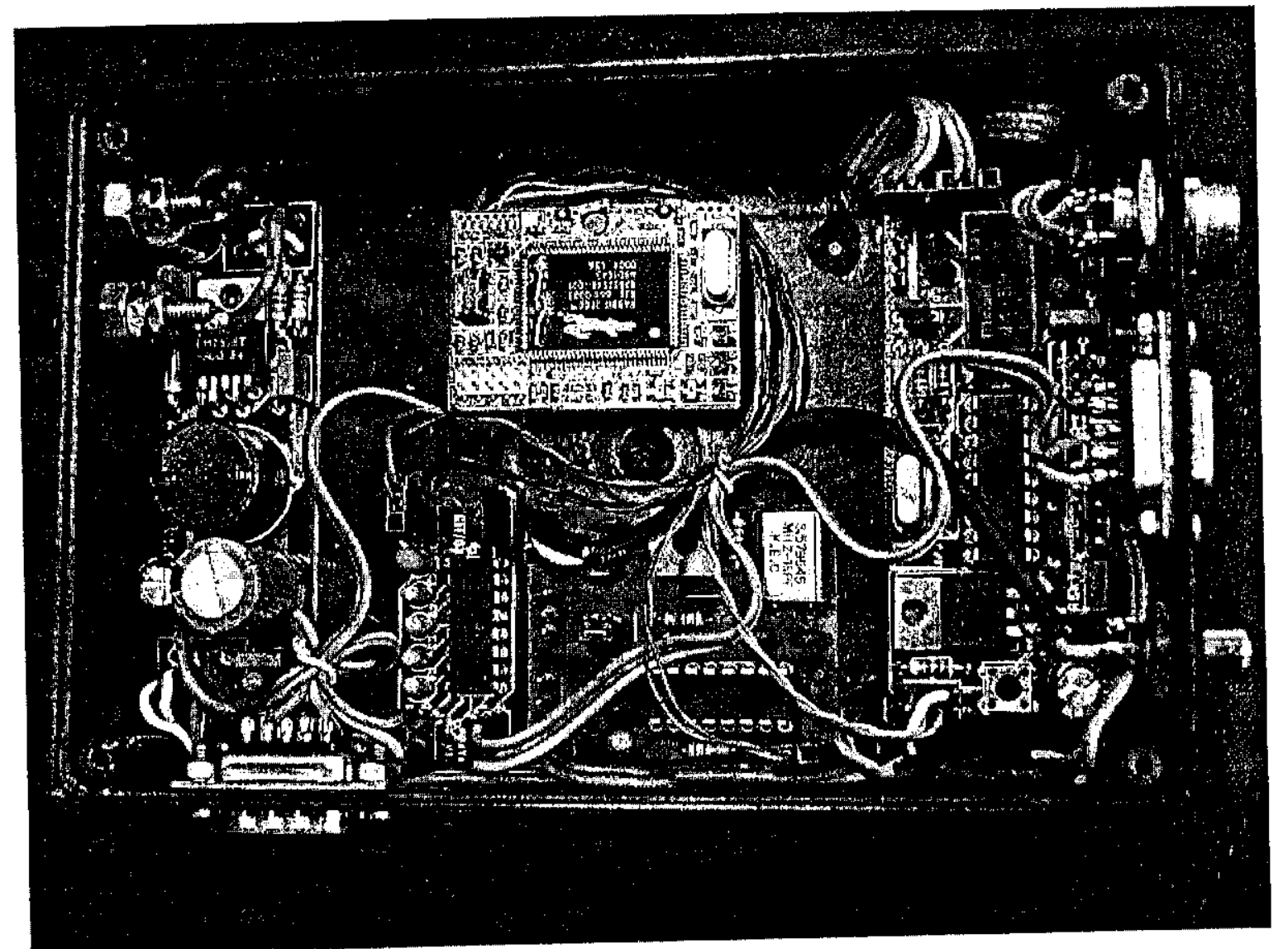

Figura 4.2: Montagem mecânica e integração dos módulos de hardware em um encapsulamento comum. 


\section{Capítulo 5}

\section{Projeto e Implementação - Software}

\subsection{Introdução}

Neste capítulo é apresentado um panorama completo do desenvolvimento de software do SciaGeo. $\mathrm{Na}$ seção 5.2 são abordadas as interfaces de software utilizadas. As seções 5.3, 5.4, 5.5 e 5.6 descrevem cada módulo de software desenvolvido: do palmtop, do processador principal, do controlador de câmera e de extração de coordenads e imagens, respectivamente. É dada uma descrição textual de cada módulo, juntamerte com o respectivo diagrama de fluxo de dados. Na seção 5.7 é apresentada a metodologia de testes utilizada.

\section{$5.2 \quad$ Interfaces}

Uma caraterística do SciaGeo é o alto nível de modularidade do sistema. Isso implica em uma alta necessidade de desenvolvimento de protocolos e software de comunicação entre os módulos presentes no sistema. Os protocolos foram definidos tomando por base conceitos importantes de sistemas distribuídos, como character stuffing e verificação de erros por CRC. A utilização desses métodos possiblitou o desenvolvimento de protocolos robustos e pouco sujeitos a perda de sincronização ou transmissão de dados incorretos.

Outro fato a ser notado quanto às interfaces é que, devido à necessidade de armazenamento de dados na trilha de áudio da filmadora, surgiu a preocupação de que não fosse especificado um protocolo que utilizasse pacotes muito grandes para transmissão de dados do GPS. Pacotes muito grandes ou com dados pouco relevantes eventualmente sobrecarregariam o canal de comunicação c forçariam a utilizayão de uma taxa mais baixa de transmissão das coordenadas.

A especificação dos protocolos de comunicação desenvolvidos para o SciaGeo é apresentada 
no Apêndice B.

\subsection{Software do Palmtop}

O principal objetivo do palmtop no SciaGeo é fazer a interface entre o operador c o sistema. A principal função do software é a de criar uma interface visual consistente, exibindo dados da missão para o operador, e transformar os comandos gerados pelo operador em dados que possam ser enviados e tratados pelo processador principal.

Corn a funcionalidade atual desenvolvida no SciaGeo, os comandos de entrada de dados pelo operador correspondem apenas ao acionamento da câmera fotográfica e da filmadora. Os dados exibidos para o operador incluem a posição geográfica atual $\mathrm{e}$ as coordenadas das fotografis disparadas. A figura 5.1 mostra um diagrama de fluxo de dados do software embarcado no módulo do processador principal.

Uma outra função desernpenhada pelo software do palmtop é o armazenamento em memória das coordenadas das fotografias e sua posterior recuperação e envio para um PC. Na figura 5.2 são apresentadas duas telas da interface desenvolvida no palmtop.

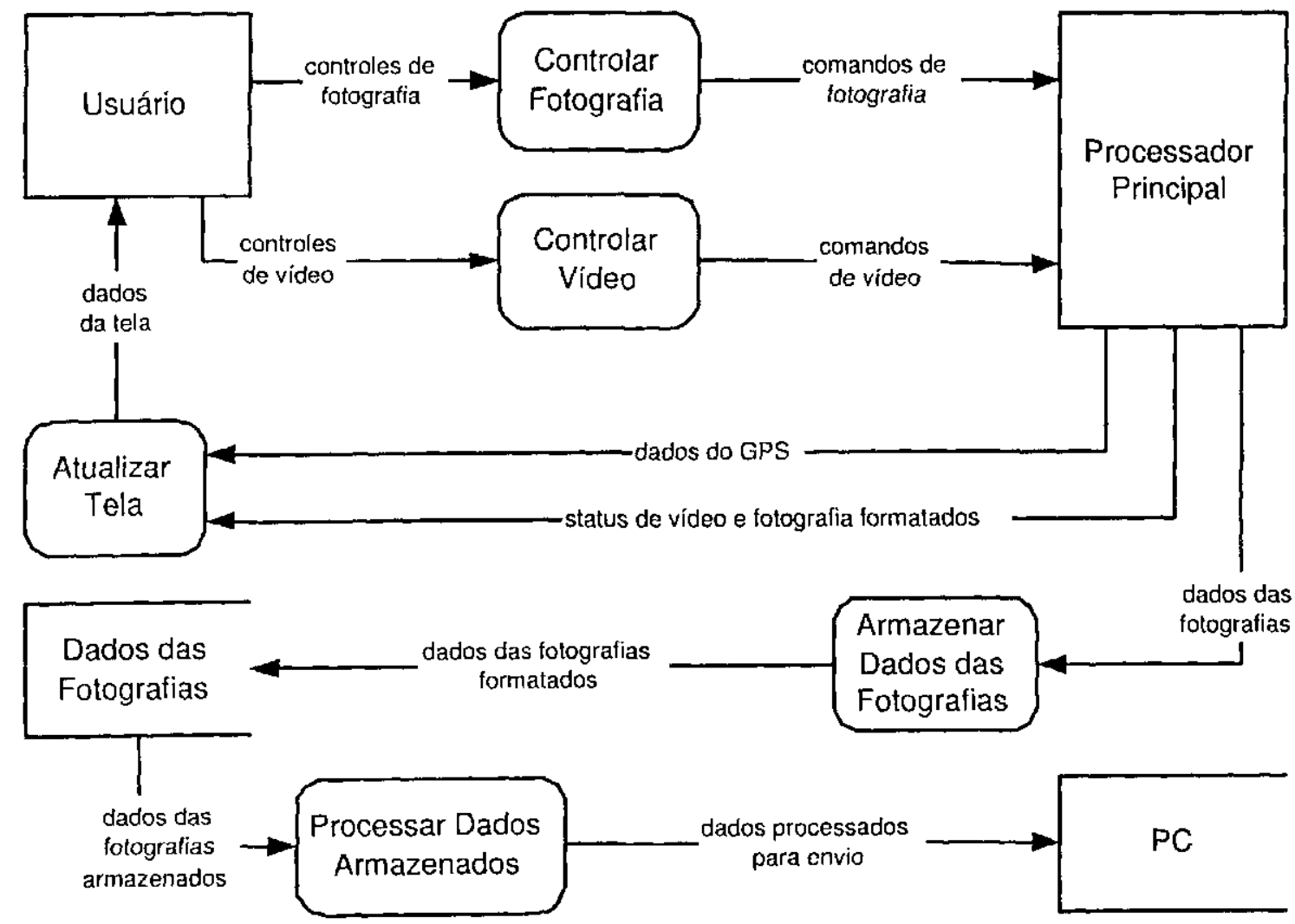

Figura 5.1: Diagrama de fluxo de dados do software executado no palmtop. 


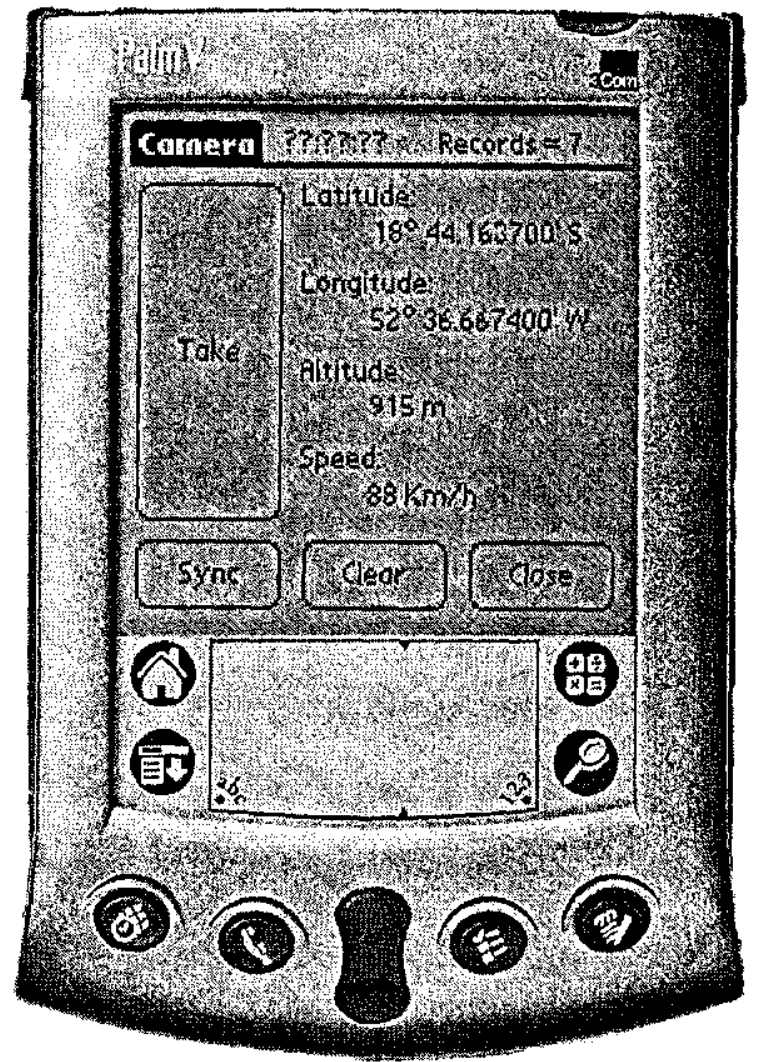

(a)

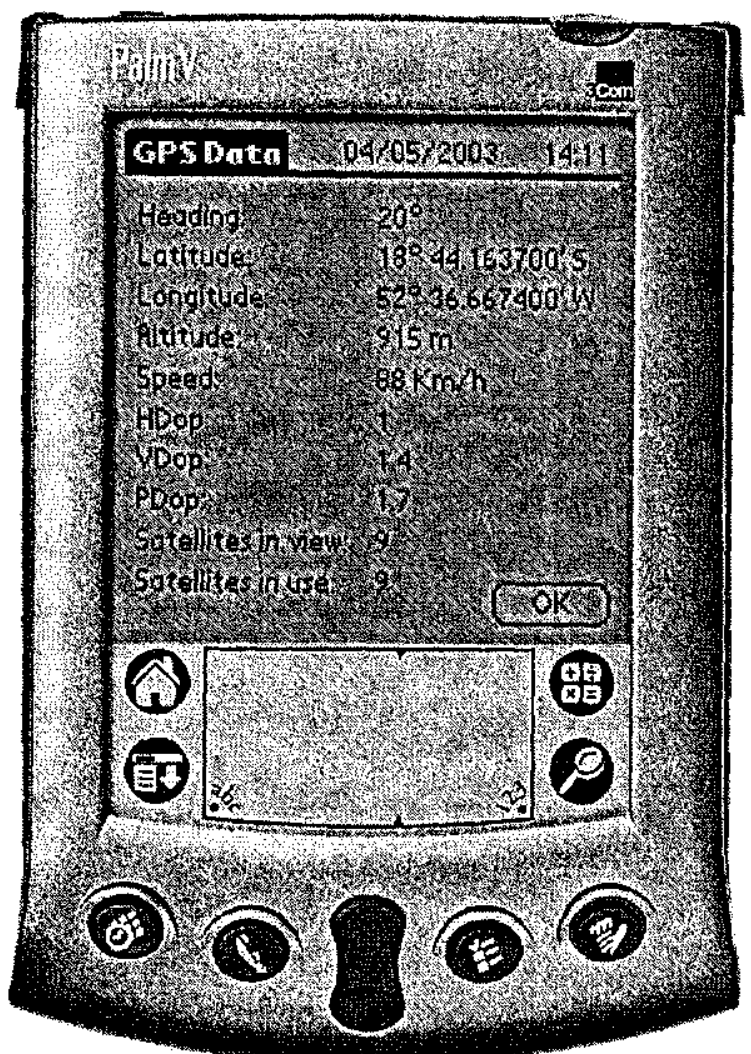

(b)

Figura 5.2: Telas capturadas do palmtop - tela de controle da câmera fotográfica (a) e tela de dados do GPS (b).

\subsection{Software do Processador Principal}

O software cmbarcado no processador principal exerce um papel de integração entre diferentes componentes presentes no sistema: receptor GPS, controlador de câmera, palmtop e filmadora (trilha de áudio).

Os dados provindos do receptor GPS são filtrados e formatados de modo a gerar un conjunto de dados conciso para armazenamento na trilha de áudio da filmadora e envio para o palmlop. Os comandos de controle das câmeras recebidos do palmtop são processados para verificação de crros c enviados para o controlador de câmera. O mesmo ocorre no caminho inverso, com os comandos de status vindos do controlador de câmera.

O processador principal do SciaGeo encontra-se de certa forma subutilizado em relação a capacidade de processamento (o que não ocorre quanto a entradas e saídas). Isso permite a expansão futura do sistema, incluindo funcionalidades como, por exemplo, gerenciamento de missão e disparo 
automático de fotografias.

Foi desenvolvido software para processar os pacotes recebidos pelo palmtop e pelo controlador de câmera, com o desenvolvimento de rotinas de character stuffing c o uso rotinas de verificação de erros por CRC. Foi necessário também desenvolver rotinas de interpretação das sentenças NMEA enviadas pelo receptor GPS.

A figura 5.3 mostra um diagrama de fluxo de dados do software embarcado no módulo do processador principal.

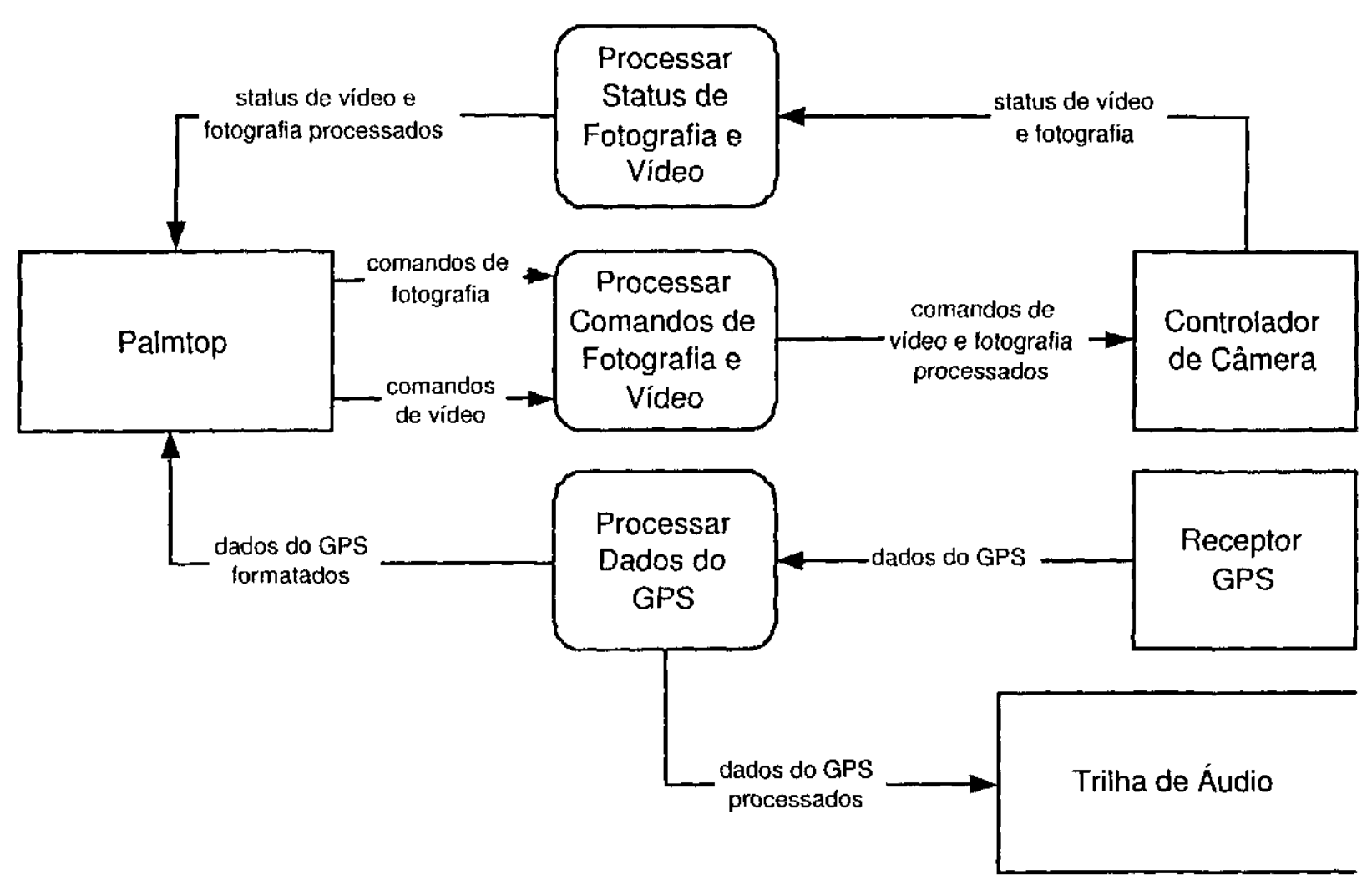

Figura 5.3: Diagrama de fluxo de dados do software do processador principal.

\subsection{Software do Controlador de Câmera}

O software do controlador de câmera tem a função de interpretar os comandos enviados pelo processador principal e usá-los para acionar as câmeras. Comandos de disparo da câmera fotográfica devem gerar um disparo no relé presente na placa, e comandos para a filmadora devem ser traduzidos para envio pelo protocolo LANC. Além disso, devem ser gcrados comandos de status (como confirmações, por exemplo) a partir dos dados recebidos das câmeras, e estes devern ser enviados para o processador principal. 
Foi desenvolvido software para processar os pacotes recebidos pela porta serial. Para isso, foi necessário desenvolver rotinas de character stuffing e utilizar rotinas de verificação de erros por CRC.

A figura 5.4 mostra um diagrama de fluxo de dados do softuare embarcado no módulo controlador de câmera.

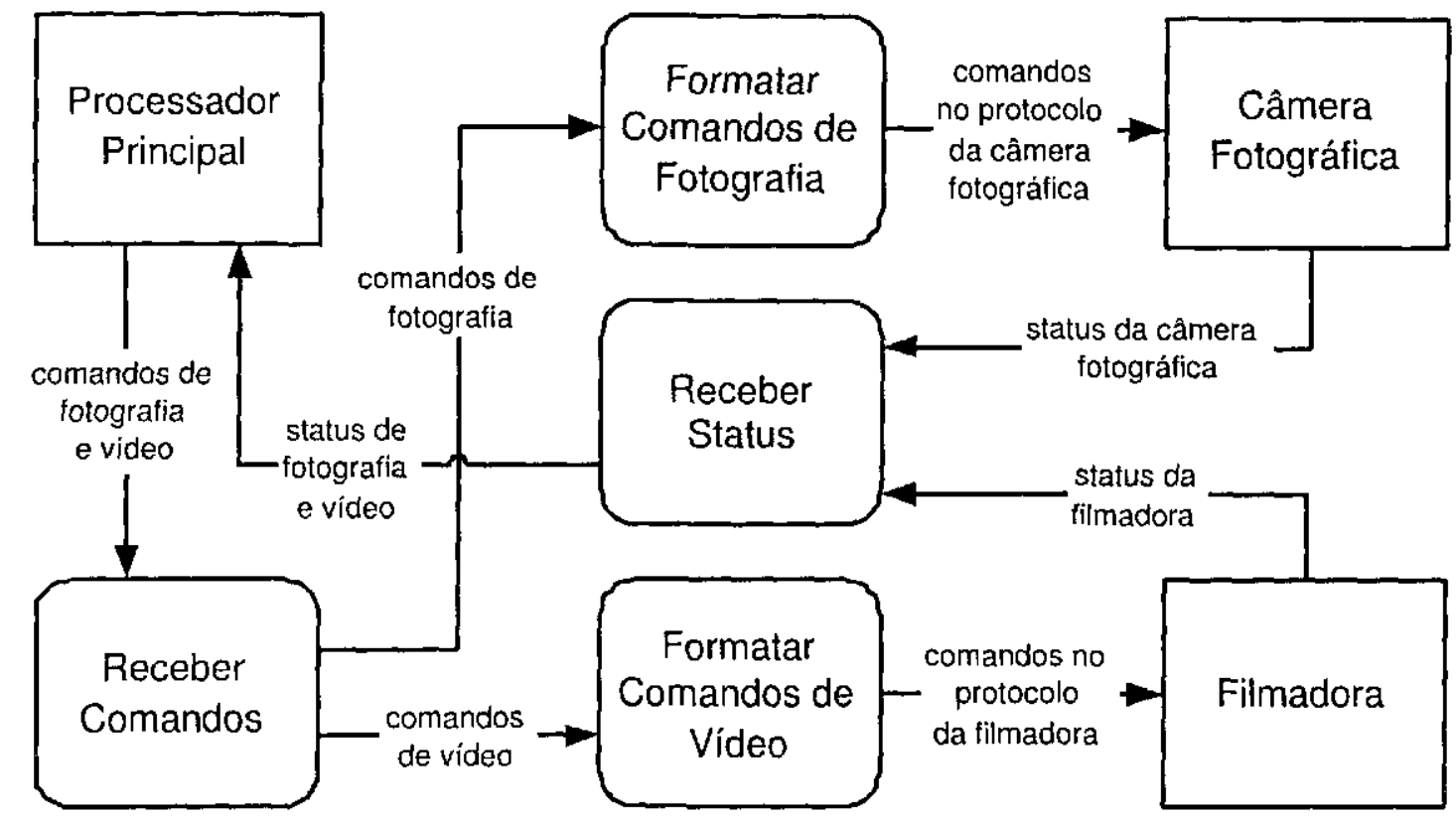

Figura 5.4: Diagrama de fluxo de dados do softuare do controlador de câmera.

\subsection{Software de Extração de Coordenadas e Quadros de Vídeo}

A função do software de extração de coordenads em imagens é gerar um conjunto de dados digital a partir dos dados contidos na filmadora. Ao final da missão, na trilha de áudio, ficam armazenados os dados de posicionamento, modulados em frequência. A gravação é feita de forma sincronizada com os quadros de vídeo. Durante a extração, o áudio é demodulado pelo modem de $2400 \mathrm{bps}$ apresentado no capítulo 4, c os dados de saída são enviados para uma porta serial no computador. Quando um pacote contendo dados de posicionamento é completamente recebido através da porta serial, imediatamente a imagem corrente presente em uma janela de captura de video é gravada em arquivo.

Os arquivos e as coordenadas gravadas são associados por índices sequenciais inseridos nos nomes de arquivo das imagens e no arquivo de coordenadas. As imagens são gravadas em arquivos de $320 \times 240$ pixels, no formato BMP de 24 bits. Um exemplo de arquivo de coordenadas 
é apresentado no Apêndice C.

A figura 5.5 mostra um diagrama de fluxo de dados do software de extração de quadros de video e de coordenadas da trilha de áudio.

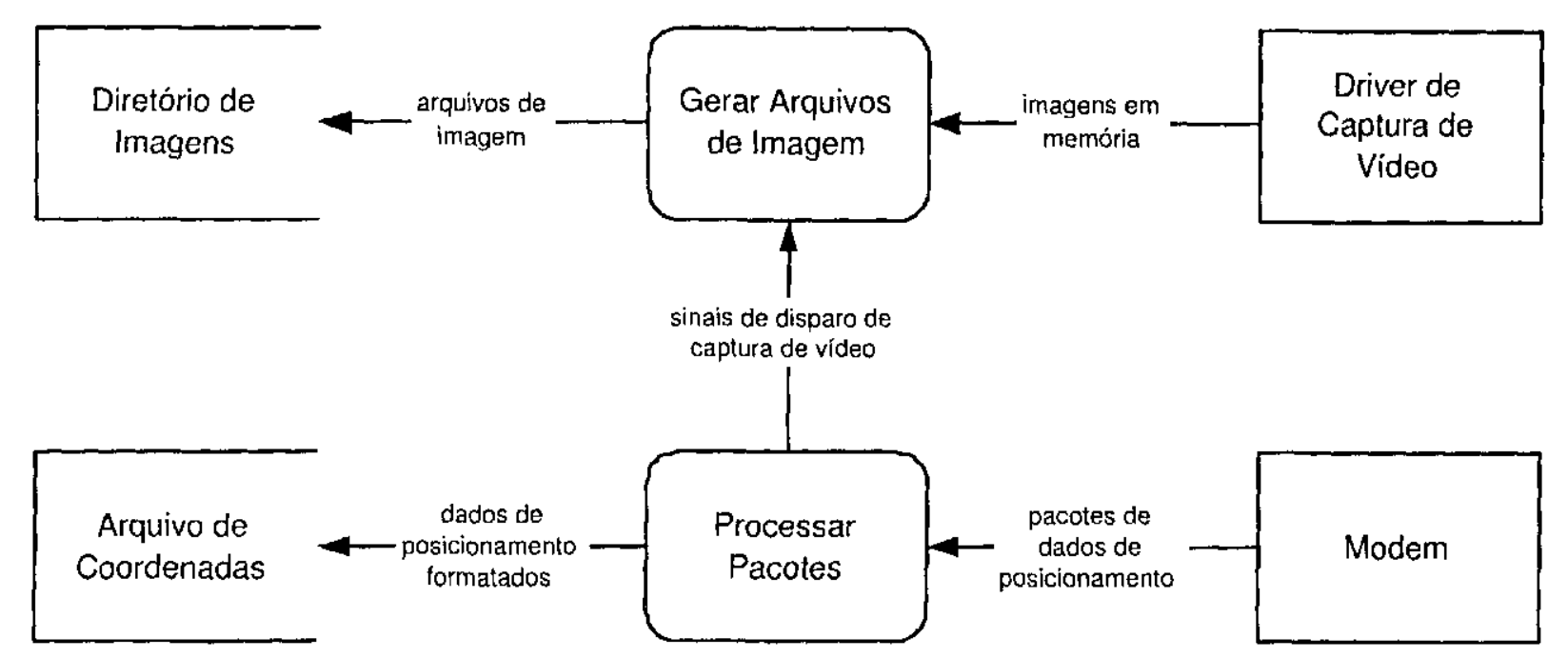

Figura 5.5: Diagrarna de fluxo de dados do software de extração e coordenadas e quadros de vídeo.

$\mathrm{Na}$ interface de extração de coordenadas e imagens existem controles disponíveis para selecionar o driver de captura de vídeo, iniciar c parar a extração. Deve-se inicialmente conectar a filmadora à entrada de vídco do PC. Após isso, basta iniciar a reprodução na filmadora e, logo em seguida iniciar a extração de dados pressionando um botão na interface. A captura de uma tela da interface de extração de coordenadas e imagens é apresentada na figura 5.6 .

\subsection{Ambiente de Implementação}

Nesta seção é descrito o ambiente de implementação utilizado para todos os componentes de software implementados neste trabalho. Essa descrição inclui linguagens, compiladores, assemblers e dispositivos de gravação dos processadores utilizados.

\subsubsection{Processador Principal}

O software do processador principal foi desenvolvido em linguagem C, com a utilização do compilador Dynamic C Premicr 7.25P, comercializado pela Rabbit Semiconductor. As bibliotecas fornecidas pelo fabricante incluem rotinas de comunicação serial e verificação de crros por CRC, que foram bastante úteis no desenvolvimento. 


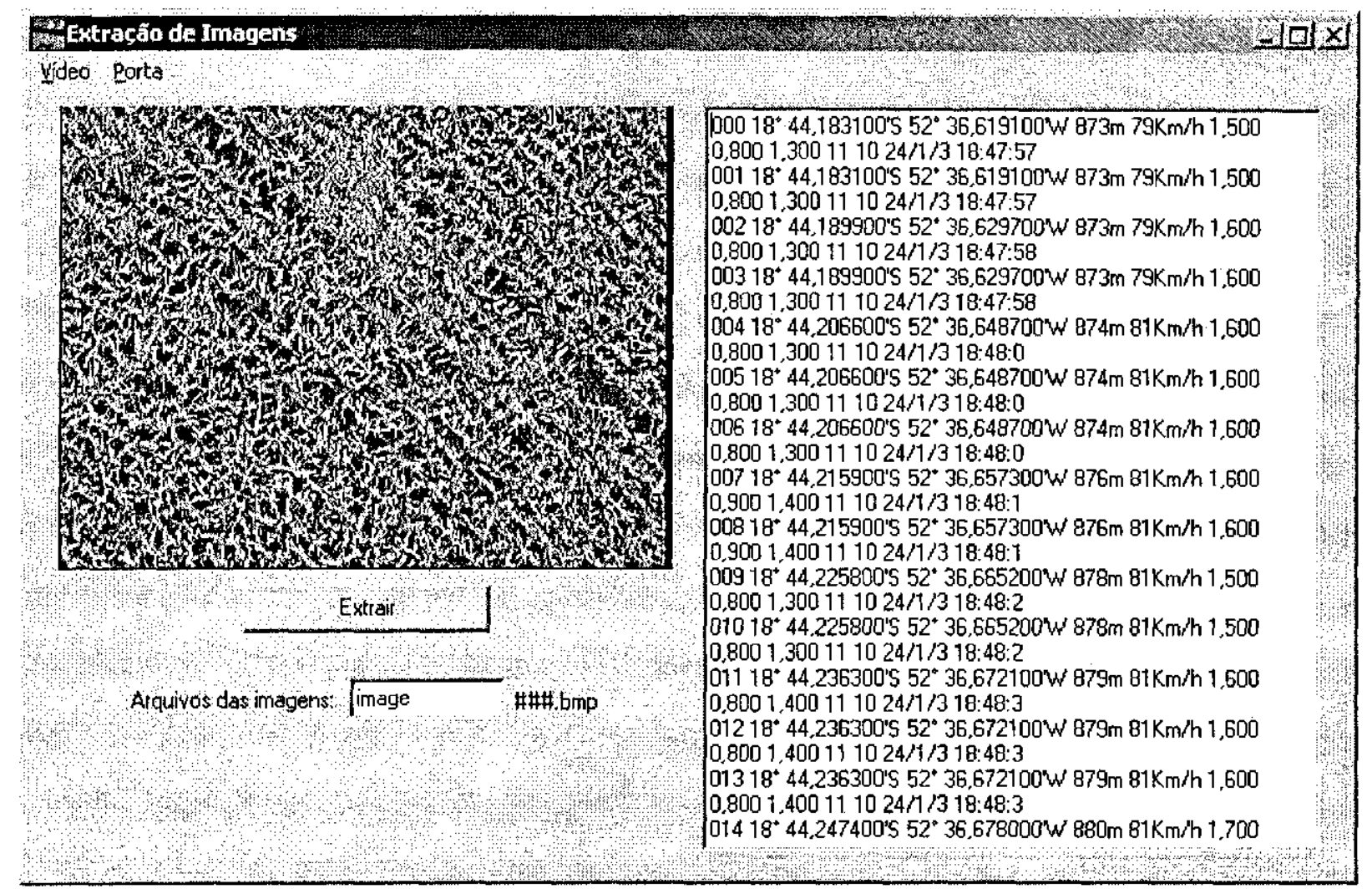

Figura 5.6: Captura de tela da interface do extrator de coordenadas e imagens.

A gravação do processador Rabbil com o código implementado se deu com a utilização de um gravador construído conforme instruções fornecidas pela própria Rabbit Semiconductor.

O software Dynamic C Premier também possui a funcionalidade de depurador in-circuit, com a utilização do mesmo dispositivo de gravacão citado no parágrafo anterior. Essa característica permite a análise de variáveis e posições de memória específicas durante a execução do programa no processador, bem como a colocação de pontos de parada (breakpoints) no código.

\subsubsection{Controlador de Câmera}

O software embarcado no módulo controlador de câmera foi desenvolvido em linguagem assembly, com a utilização do assembler gratuito MPL $\Lambda$ B IDE fornecido pela Microchip Inc. Não foram utilizadas biliotecas de terceiros, exceto pelas rotinas de verificação de erros por $\mathrm{CRC}$, também fornecidas pela própria Microchip Inc.

O hardware utilizado para gravação do PIC16F628 foi o PicAll, juntamente com o software de gravação PicAllW. Não foram utilizados dispositivos de depuração in-circuit. 


\subsubsection{Palmtop}

Foi utilizada a linguagem C com o compilador Metrowerks CodeWarrior versão 4.1.0.2 para implementação do software executado no palmtop. Foram utilizadas as biliotecas fornecidas pelo fabricante para comunicação serial, componentes gráficos e armazenamento de registros em momória.

\subsubsection{Software de Extração de Imagens e Coordenadas}

Para o desenvolimento do softuare de extração de coordenadas e imagens, foi utilizado o compilador Borland Delphi 6. Foram utilizados componentes de captura de vídeo de código aberto.

\subsection{Testes Modulares e de Integração}

Inicialmente, foram executados testes em bancada com cada módulo de hardware equipado com o softuare final. Após validada a operação de cada módulo e corrigidos os erros, foram realizados testes de integração onde puderam ser identificadas incompatibilidades entre os módulos, tanto de hardware quanto de software. Essas incompatibilidades foram corrigidas nessa etapa do projeto.

Após os testes prelininarcs de integração, foram realizadas curtas missões piloto em solo para validar todo o processo, desde a captura das imagens até a geração dos arquivos de coordenadas e de imagens digitalizadas.

\subsection{Considerações Finais}

Neste capítulo foi abordado o desenvolvimento de software realizado neste trabalho. Inicialmente, foram descritos os métodos utilizados no desenvolvimento das interfaces de comunicação. Vários os módulos de softuare foram implementados, e foram apresentadas neste capítulo descriçōes de cada um, juntamente com diagramas de fluxo de dados mostrando de forma clara o funcionamento de cada módulo. Foram apresentados também os ambientes de desenvolvimento utilizados e a metodologia de testes para validação dos subsistemas e do sistema integrado.

O próximo capítulo descreve como o sistema deve ser operado, desde a instalação até a recuperação dos dados resultantes. 


\section{Capítulo 6}

\section{Instalação e Operação do SciaGeo}

\subsection{Introdução}

Neste capítulo são especificados os procedimentos a serem seguidos para a correta instalação e opcração do SciaGeo. Os requisitos de instalação são aprescntados na seção 6.2. Os procedimentos de operação podem ser divididos em três fases: pré-vôo, durante o vôo e pós-vôo. Essas fases são descritas nas seções $6.3,6.4$ e 6.5 , respectivamente.

\subsection{Instalação do Equipamento}

$\Lambda$ instalação do SciaGco na aeronave é simples, mas devem ser satisfeitos alguns requisitos básicos.

De forma resumida, são cles:

- Posicionamento do cixo das câmeras de forma perpendicular aos cixos de rolagem c arfagem da aeronave;

- Minimização da vibração nas câmeras;

- Fácil acesso do operador às câmeras durante o vôo.

A fixação da câmera fotográfica e da filmadora de forma perpendicular aos eixos de rolagem c arfagem deve ser feita visando a obtenção de imagens aéreas verticais durante um vôo nivelado da aeronave. Deve ser instruído ao piloto que seja executado um vôo nivelado quando a área de interesse estiver sendo sobrevoada. Não é necessário que esse procedimento de ajuste na instalação seja feito com instrumentos de precisão - um simples ajuste visual já é suficiente para obter um nível de verticalidade aceitável para as imagens. 
Deve-se tomar o cuidado, durante a instalação, de utilizar algum material ou montagem que minimize a vibração nas câmeras. 'Toda aeronave produz algum tipo de vibração, notadamente a vibração proveniente do motor. Essa vibração pode deteriorar as imagens obtidas. Por mais rápido que sejam os obturadores das câmeras, esse detalhe da montagem deve ser observado com cuidado. Caso sejam notados problemas de vibração, deve-se utilizar montagens com borrachas cada vez mais macias para fixação das câmeras à aeronave, eventualmente aumentando a massa do sistema (no caso, as câmeras).

O SciaGeo permite, para missões longas, que o filme e/ou fita de vídeo das câmeras seja trocado durante o vôo. Para isso, deve-se instalar as câmeras de forma que o operador tenha acesso manual a elás durante o vôo.

\subsection{Operação Pré-Vôo}

Após a instalação do SciaGeo na aeronave, os seguintes passos devem ser seguidos antes da decolagem:

1. Planejamento do vôo de forma conjunta pelo operador e pelo piloto (detalhes na seção 6.4);

2. Carregar as baterias do sistema se necessário (câmeras e bloco eletrônico);

3. Carregar a filmadora com uma fita de video apropriada e rebobinada;

4. Carregar a câmera fotográfica com o filme apropriado;

5. Ligar o bloco eletrônico;

6. Ligar o palmtop;

7. Ligar a câmera fotográfica e ajustar seus parâmetros;

8. Ligar a filmadora, ajıstar seu parâmetros e iniciar a gravação.

Após a exccução desses passos, o procedimento de decolagem da aeronave pode ser executado pelo piloto.

\subsection{Operação Durante o Vôo}

Após a decolagem, o plancjamento do vôo citado na seção anterior deve ser seguido pelo piloto. Os seguintes cuidados devem ser tomados pelo piloto e pelo operador no planejamento do vôo e durante o vôo: 
- Manter as asas da aeronave niveladas durante o sobrevôo das áreas de interesse

- Determinar um limite de velocidade com base no ajuste das câmeras e não excedê-lo durante o sobrevôo da área de interesse

- Determinar a altitude ideal em relação ao solo para obterıção das imagens

As asas devem ser mantidas niveladas para permitir a obtenção de imagens verticais. Um grande desvio do eixo das câmeras em relação à vertical pode comprometer a precisão do georeferenciamento, uma vez que a imagem obtida estaria deslocada no solo, não correspondendo à posição obtida pelo receptor GPS instalado na aeronave. A lém disso, o processamento das innagens pode ser prejudicado por imagens oblíquas, uma vez que as medições efetuadas perderiam a uniformidade na área imageada.

Durante o vôo, o operador deve disparar as fotografias nos locais de interesse e trocar o filme fotográfico quando necessário. A troca de filme ocorre de forma convecional, como se o operador estivesse operando a câmera manualmente.

A troca da fita de vídco também deve ser feita pelo operador quando a mesma tiver sido esgotada. A troca também é feita de forma convencional, parando a gravação, trocando a fita e reiniciando a gravação, sem desligar o sistema.

O sistema pode ser operado pelo próprio piloto da aeronave, desde que a missão seja curta o suficiente para que não haja troca de filme ou fita de vídeo, restando apcnas a tarefa de disparo das fotografias para ser executada. Para missões mais longas, é recomendável que haja um operador específico para o SciaGeo, uma vez que o piloto pode ficar sobrecarregado, comprometendo a segurança de vôo.

\subsection{Operação Pós-Vôo}

Após o pouso, deve se realizar os seguintes passos:

1. Desligar todos os equipamentos;

2. Desmontar o equipamentos da aeronave;

3. Recuperar as imagens da câmera fotográfica;

4. Recuperar as coordenadas das imagens de alta resolução; 
5. Recuperar imagens de baixa resolução e as respectivas coordenadas utilizando o software de extração de quadros de vídeo.

A recuperação das imagens de alta resolução deve ser feita descarregando-se as imagens em um PC no caso de uma câmera digital e digitalizando as imagens reveladas ou os negativos no caso de uma câmera convencional. A associação das ccordenadas às imagens fica a critério do usuário do sistema, que deve criar arquivos e associá-los logicamente às coordenadas da mancira que preferir.

Com a utilização de câmeras fotográficas convencionais, deve-se tomar o cuidado especial de organizar as imagens na ordem em que foram disparadas, para que as coordenadas extraídas do palmtop possam ser associadas às fotogxafias facilmente. Nesse caso, o sistema não possui recursos para fazer uma associação automática das coordenadas, e a falha do operador na organização das imaggens pode inviabilizar a sua utilização.

No caso das imagens de baixa resolıção, o próprio software de extração associa automaticamente as coordenadas às imagens, criando um arquivo de coordenadas imagens com ordenação pelo nome do respectivo arquivo. Resta ao usuário fazer a conversão para o formato aceito pelo SIG em que os dados serão inseridos.

\subsection{Considerações Finais}

Neste capítulo foram apresentadas instruções gerais sobre como o equipamento deve ser operado, incluindo os principais requisitos que devem ser satisfeitos pelos opcradores do sistema. Foi descrita a instalação do sistema, que ć muito simples e necessita apenas de um pequeno local de fixação na parte inferior da acronave. As operações pré-vôo, durante o vôo e pós-vôo foram apresentadas em sequências de instruções simples, para facilitar o entendimento dos operadores e minimizar falhas. Estas sequências de instruções podem scr utilizadas como listas de checagem para as operações em campo.

No próximo capítulo pode ser vista a aplicação das instruções contidas nesse capítulo cm uma missão real. 


\section{Capítulo 7}

\section{Resultados}

\subsection{Introdução}

Neste capítulo são descritos os resultados obtidos em uma operação real com o SciaGeo. Além dos testes realizados em bancada para validação do sistema, uma operação em campo foi realizada para validar o sistema nas condições reais de operação, tanto da integração física (ex.: instalação do equipamento na aeronave) quanto da interação entre o operador e o sistema.

Outro objetivo importante do teste em condições reais ć gerar um conjunto de imagens da cultura monitorada que pode ser utilizado em trabalhos futuros de processamento de inagens. $O$ desenvolvimento de tais trabalhos validaria o uso do sistema como um todo, incluindo os sensores utilizados, com resultados valiosos para o produtor rural.

Na seção 7.2 é dado um panorama geral da missão. Na seção 7.3 é citado como foi feita a inst.alação do equipamento. Na seção 7.4, é apresentada uma descrição de como o equipamento foi operado durante a missão. Na seção 7.5 são apresentados os dados de saída do sistema para a missão de teste. Finalmcnte, na seção 7.6, são apresentadas algumas consideraçōes finais sobre a missão realizada.

\subsection{A Missão na Fazenda Campo Bom}

A missão de teste foi realizada na Fazenda Campo Bom, localizada nos estados de Mato Grosso do Sul e Goiás, com uma área cultivada de cerca de 20 mil hectares. O local específico em que foi operado o sistema situa-se próxino à cidade de Chapadão do Sul, no estado de Mato Grosso do Sul. A Fazenda Campo Bom possui como principais culturas a soja e o milho, c utiliza o método de plantio direto. 
O plantio é rcalizado em talhões com cerca de 200 hectares cada um. Normalmente cada talhão é tratado de mancira uniforme quanto à aplicação de insumos. Com trabalhos de coleta de dados para agricultura de precisão, como no caso do SciaGeo, pretende-se tratar diferentes pontos de um mesmo talhão de forma diferenciada, aumentando a produtividade e minimizando o desperdício de insumos, como adubos c defensivos agrícolas.

\subsection{Instalação do Equipamento}

\subsubsection{Câmeras, Lente e Filme Utilizados}

As imagens de alta resolução foram obtidas usando uma câmera $35 \mathrm{~mm}$ convencional, antomática, SLR (Single-Lens-Reflex) da marca Minolta, modelo Maxxum 5. A lente utilizada possui distância focal de $50 \mathrm{~mm}$, com uma abertura de diafragma máxima de f1.8. O filme utilizado foi padrão ISO 400.

As imagens de baixa resolução foram obtidas com uma filmadora digital MiniDV da marca Sony, modelo PC110. As fitas MiniDV possuem capacidade para 90 minutos no modo LP (média qualidade) e 60 minutos no modo SP (qualidade padrão). A gravação foi feita no modo SP, e foram utilizadas duas fitas, totalizando duas horas de filmagem.

\subsubsection{Fixação do Equipamento na Aeronave}

A fixação do equiparnento na aeronave foi realizada de forma bastante simples. Foi utilizada uma. barra de aço fixada por tiras de nylon aos tubos de alumínio próximos ao trem de pouso. O detalhe da montagem pode ser obscrvado na figura 7.1.

Mantas de borracha foram utilizadas sobre a barra para minimizar o efeito da vibração da aeronave sobre as câmeras, o que poderia comprometer a qualidade das imagens obtidas. Esse método de fixação mostrou-se eficiente, uma vez que as imagens apresentaram uma boa qualidade, sem efeitos de "borrão" por movimento da câmera.

O posicionamento do eixo das câmeras de forma perpendicular às asas da aeronave foi feito de forma visual. As câmneras foram facilmente posicionadas próximo ao operador do sistema para troca de filmes e fita de vídeo durante o vôo. 


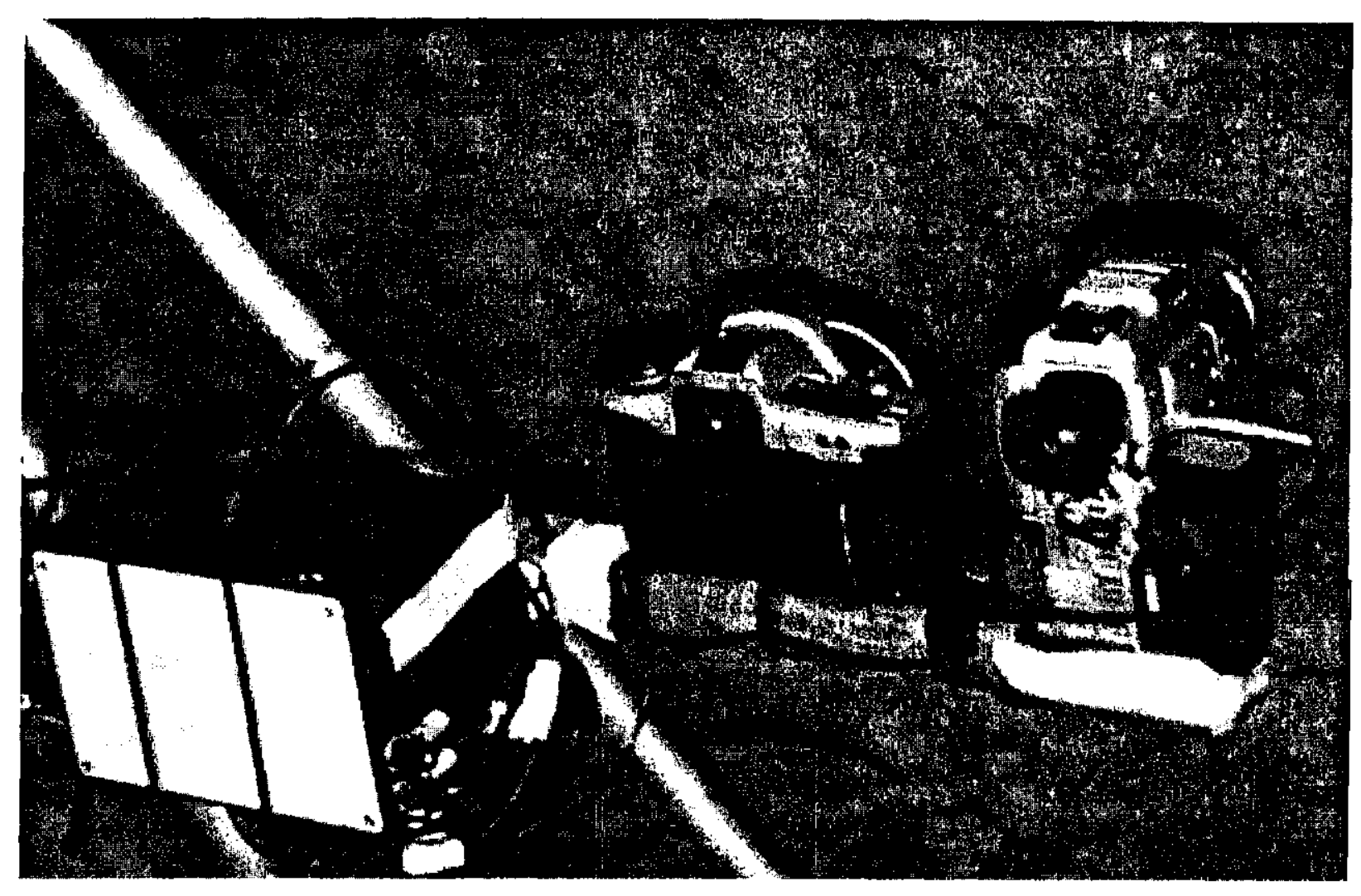

Figura 7.1: Detalhe da montagem do SciaGeo na aeronave.

\section{4 Área Monitorada}

Quatro talhões da Fazenda Campo Bom foram selecionados para estudo, sendo dois plantados com milho e dois plantados com soja. Para cada tipo de cultura, uma área apresentava bom desenvolvimento e a outra apresentava algum nível de infestação por pragas, plantas daninhas ou falhas no plantio. Forann também obtidas algumas imagens isoladas de uma cultura de algodão próxima às áreas de soja e milho.

A figura 7.2 mostra um mapa da região monitorada, indicando os quatro talhōes de soja e milho citados anteriormente, juntamente com as coordenadas geográficas dos vértices dos mesmos.

\subsection{Operação do SciaGeo}

$\Lambda$ rnissão na Fazenda Campo Bom foi realizada dentro dos padrões esperados para a opcração do SciaGco. $\Lambda$ missão foi realizada utilizando-se um acronave do tipo ultraleve convencional, de asa alta e com capacidade para dois ocupantes. Foi alocado um funcionário da fazenda para a operação do sistcma em vôo, deixando para o piloto apenas a tarefa de controle e navegação da aeronave. $\Lambda$ figura 7.3 mostra uma imagem do piloto e do operador na acronave, com o hardware do SciaGeo 


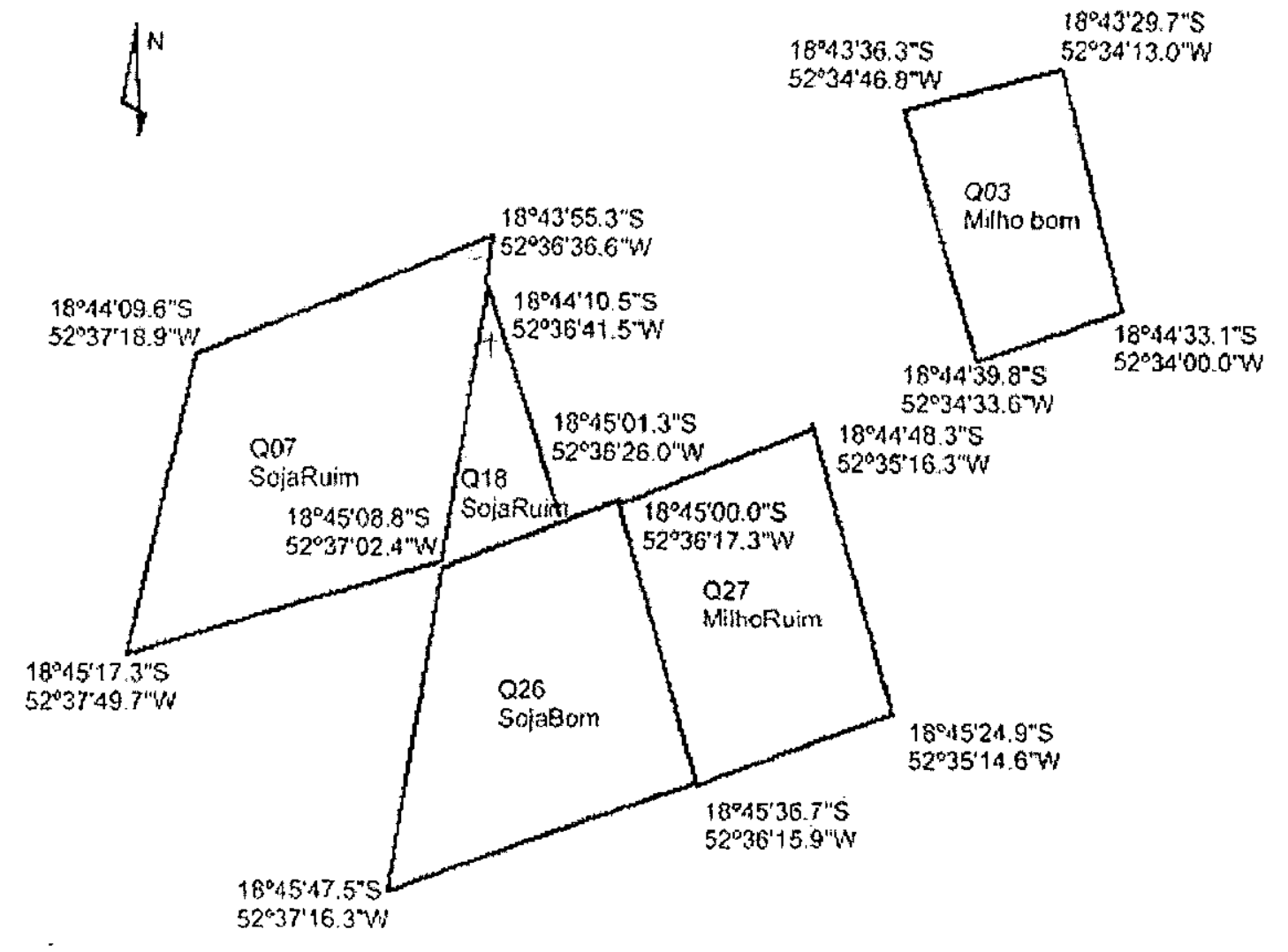

Figura 7.2: Mapa da região indicando os talhões monitorados.

instalado.

Foram sclecionados previamente alguns pontos específicos da cultura que apresentavam problemas para que fossem obtidas as imagens de alta resolıção. No momento em que tais áreas eram sobrevoadas (conforme identificado pelo operador), fotografias eram disparadas.

Nenhum evento fora do especificado foi notado durante a operação. Tudo ocorreu conforme planejado. O dia estava nublado, mas sem vento.

\subsection{Dados Resultantes da Missão}

Como resultado da missão, foi obtido um conjunto total de cerca de 300 imagens de alta resolução e 12000 imagens de baixa resoluçâo. Com o auxílio de pesquisadores da Embrapa na área de agricultura de precisão e processamento de imagens, foi realizada a avaliação visual e segmentação por computador de algumas das imagens.

Foram utilizados durante a missão oito rolos de filmes fotográficos de 36 poses, padrão ASA 400, da marca Fuji. Cada rolo de filme resultou cm 37 fotografias, em média. As imagens da câmera 


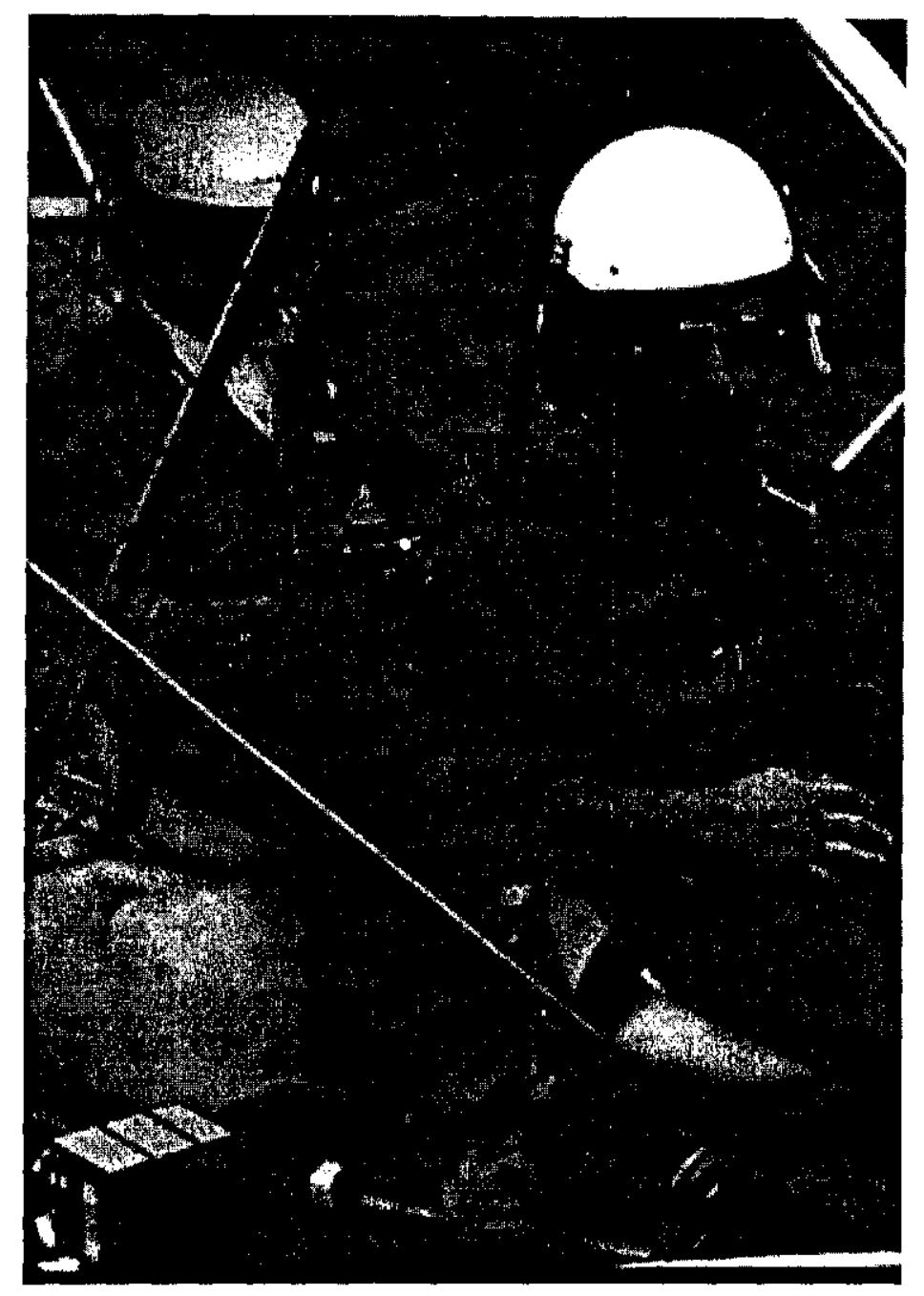

Figura 7.3: Piloto e operador do SciaGeo a bordo da acronave com o hardware do SciaGeo acoplado (no canto inferior esquerdo da imagem).

fotográfica foram reveladas e o processo de digitalização foi realizado a partir dos negativos das imagens, com o uso de um scanner. A resolução da digitalização foi ajustada para 2400 dpi. As imagens resultantes apresentavam escala de 1 a $2 \mathrm{~cm}$ no solo para cada pixel da inagem digital.

$\Lambda$ s imagens digitalizadias de alta resolução apresentaram ótima qualidade, sem a presença de anomalias em relação movimento ou vibração. Gravadas no formato TIFF, sem compactação, com profundidade de cor de 24 bits, as imagens finais apresentaram resolução de aproximadamente $3200 \times 2200$ pixels, ocupando um espaço em disco de 21364 kilobytes.

As imagens de baixa resolução foram obtidas da filmadora por meio de digitalização de vídeo analógico. As imagens foram digitalizadas com uma resolução de 320x240 pixels, uma vez que essa é a resolução nominal do sensor de imageamento da filmadora. As imagens foram gravadas no formato BMP, ocupando um espaço cm disco de 226 kilobytes cada uma, sem compactação. A 
escala apresentada pelas imagens foi de cerca de $10 \mathrm{~cm}$ no solo para cada pixel da imagem.

Para efeito de comparação entre as imagens de diferentes resoluções, são apresentados na figura 7.4 detalhes de um veículo parado em solo, cujas imagens foram obtidas em uma passagem da aeronave sobre o mesmo.

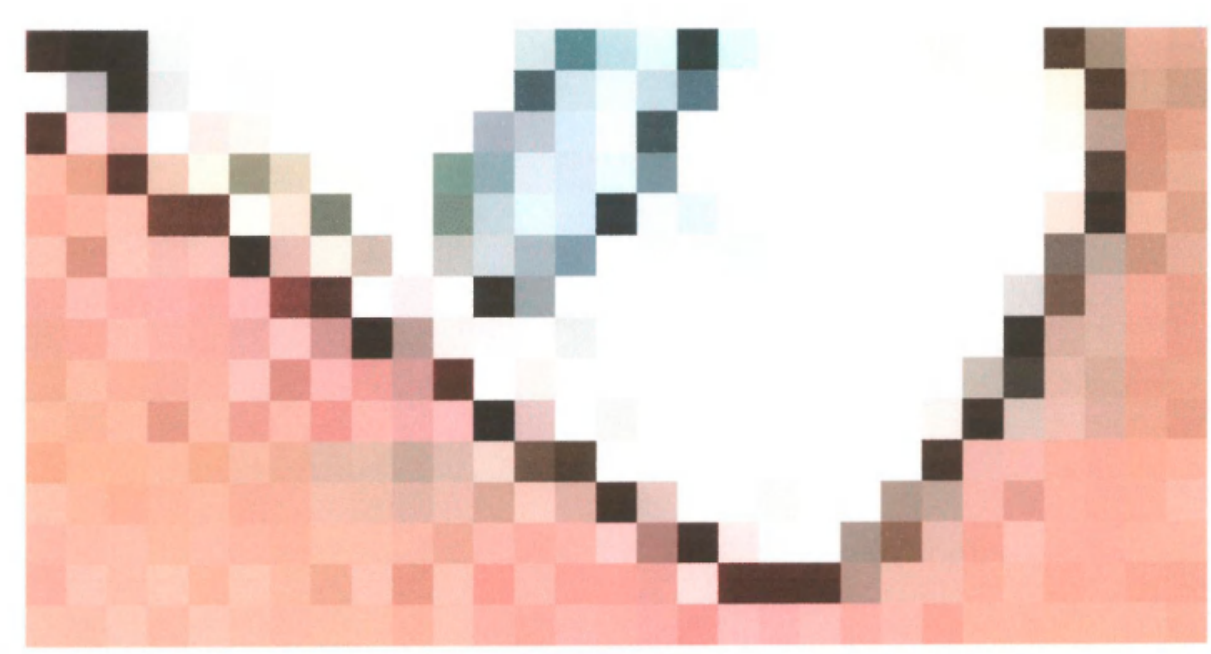

(a)

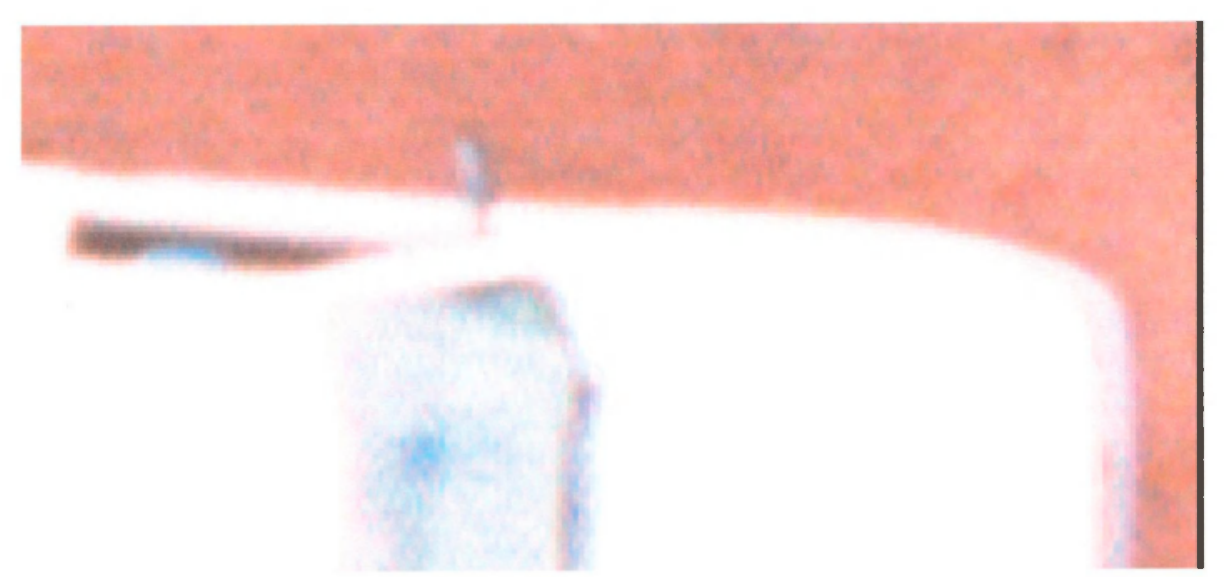

(b)

Figura 7.4: Detalhe de um veículo visto em solo por meio de imagens de baixa (a) e alta (b) resolução 


\subsubsection{Análise Visual das Imagens}

Algumas características importantes da cultura puderam ser identificadas por meio de uma análise visual, executada por um pesquisador da Embrapa. Tanto as imagens de alta resolução quanto as de baixa resolução permitiram uma análise visual satisfatória. As principais caraterísticas observadas foram:

- Infestação por plantas invasoras;

- Infestação por pragas;

- Falhas no plantio.

A seguir, são apresentadas algumas imagens de baixa resolução obtidas pela filmadora. São mostradas imagens de regiões semelhantes, com e sem a presença dos problemas citados. Para efeito de comparação, as imagens foram obtidas em várias escalas diferentes, correspondedo a altitudes diferentes de vôo. As figuras 7.5, 7.6 e 7.7 mostram imagens da cultura de soja com e sem falhas de plantio, em diferentes altitudes.

Além de falhas no plantio, pode-se observar também, nas figuras 7.9 e 7.8 a presença ou não de plantas invasoras na cultura, em diferentes escalas de imagem.

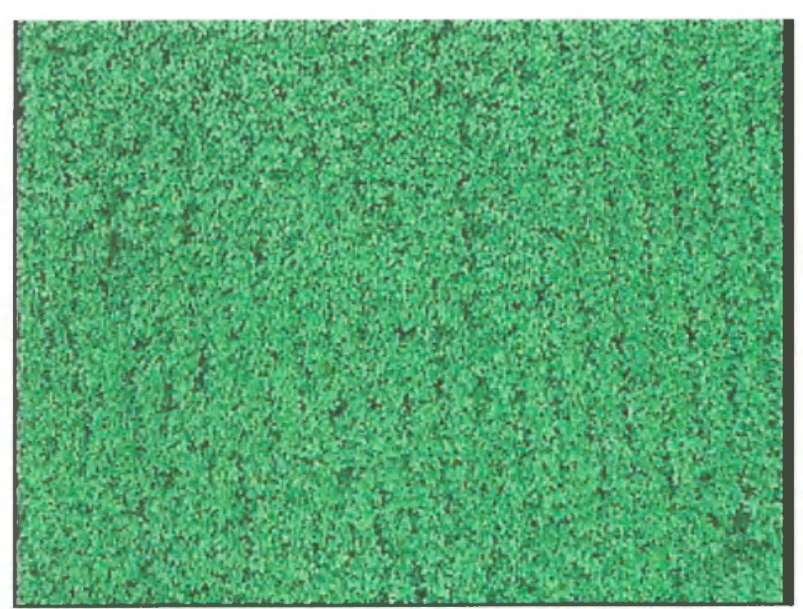

(a)

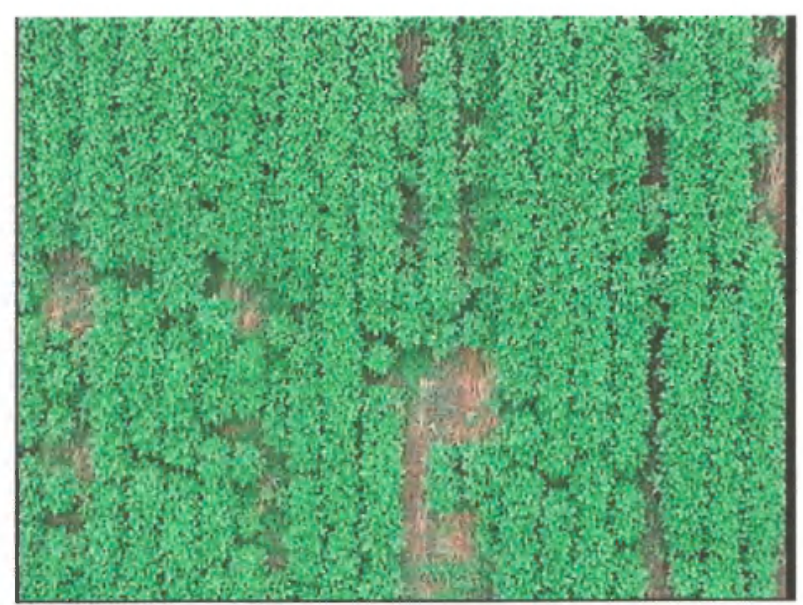

(b)

Figura 7.5: Imagens em escala reduzida de soja sem problemas (a) e com falhas de plantio (b) 


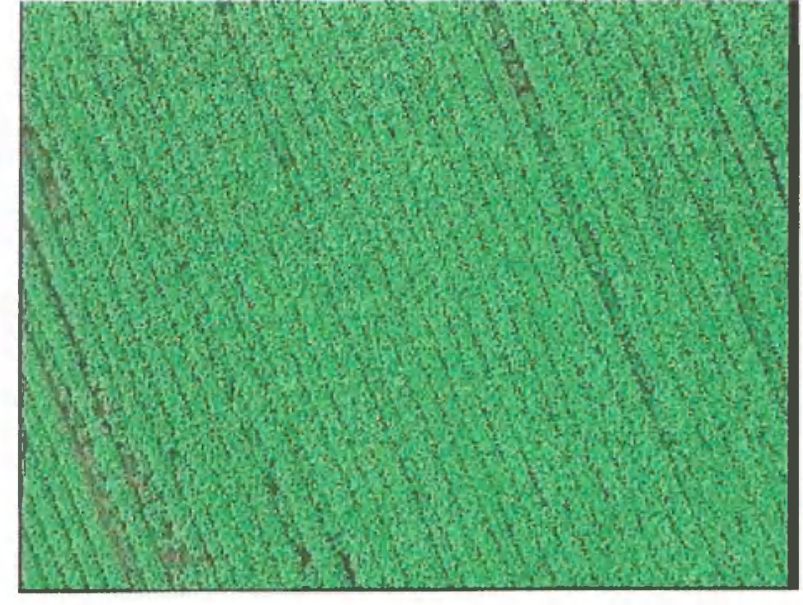

(a)

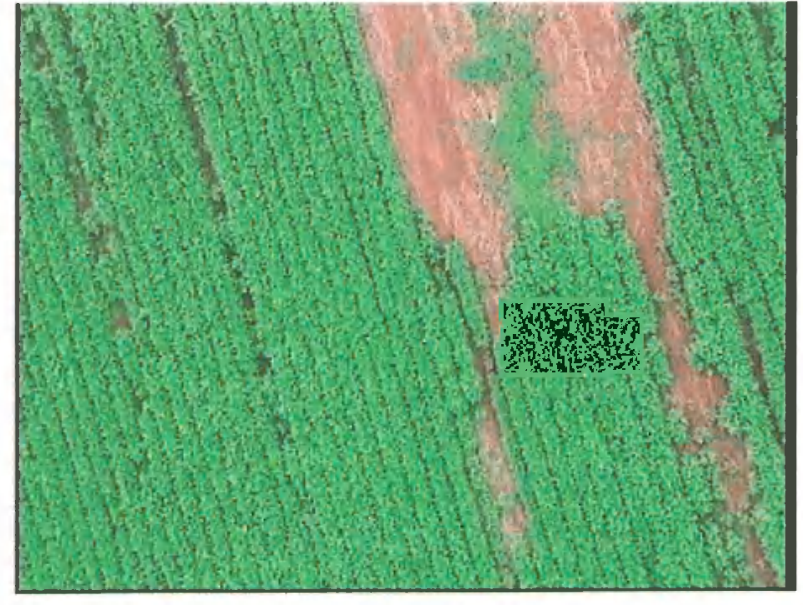

(b)

Figura 7.6: Imagens em média escala de soja sem problemas (a) e com falhas de plantio (b)

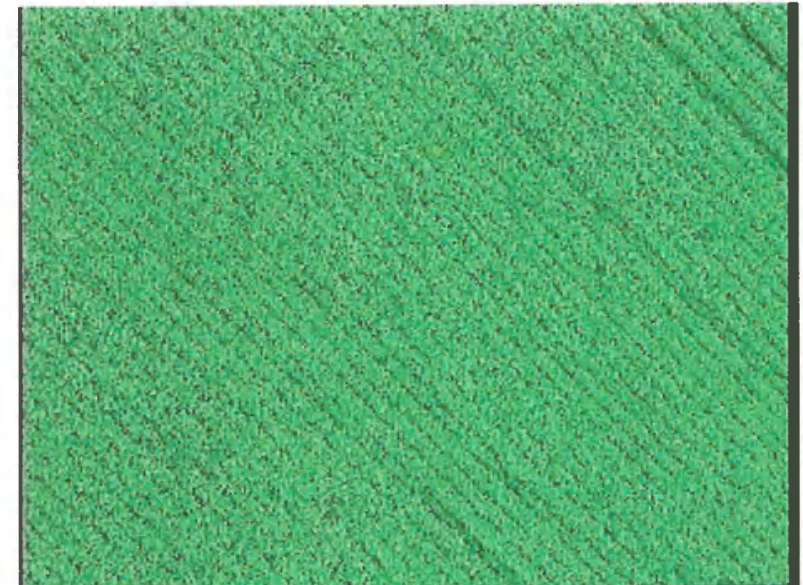

(a)

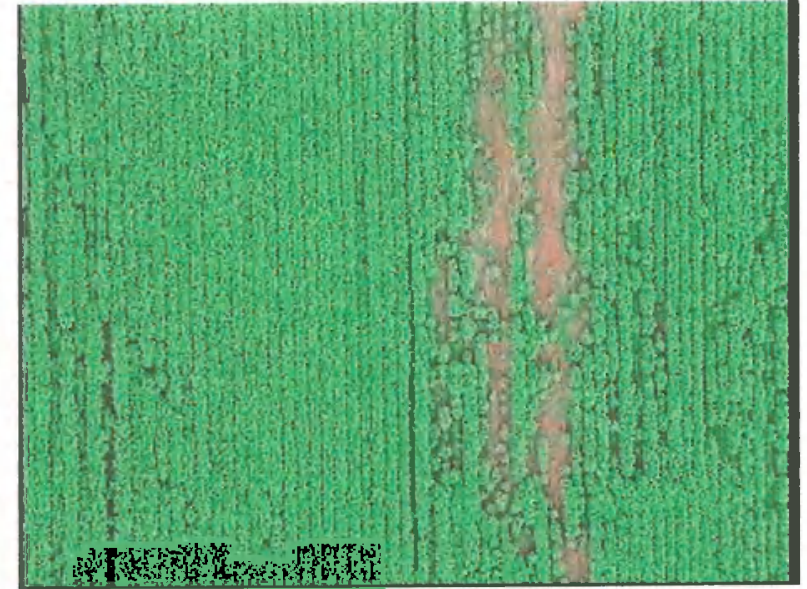

(b)

Figura 7.7: Imagens em grande escala de soja sem problemas (a) e com falhas de plantio (b) 


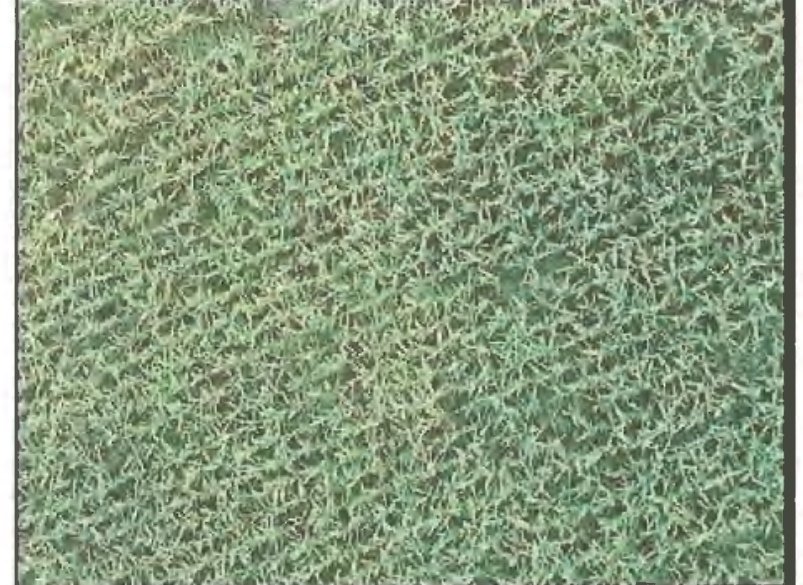

(a)

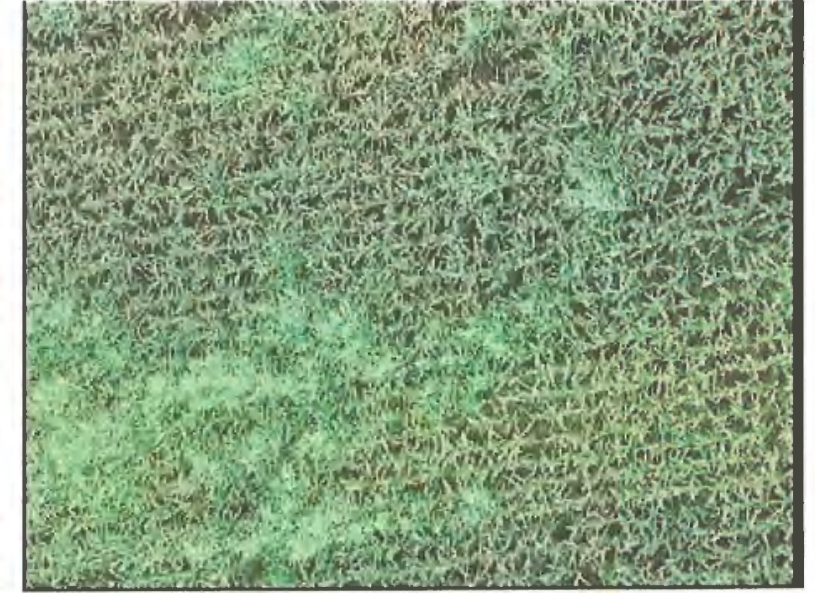

(b)

Figura 7.8: Imagens em escala reduzida de milho sem (a) e com (b) presença de plantas invasoras.

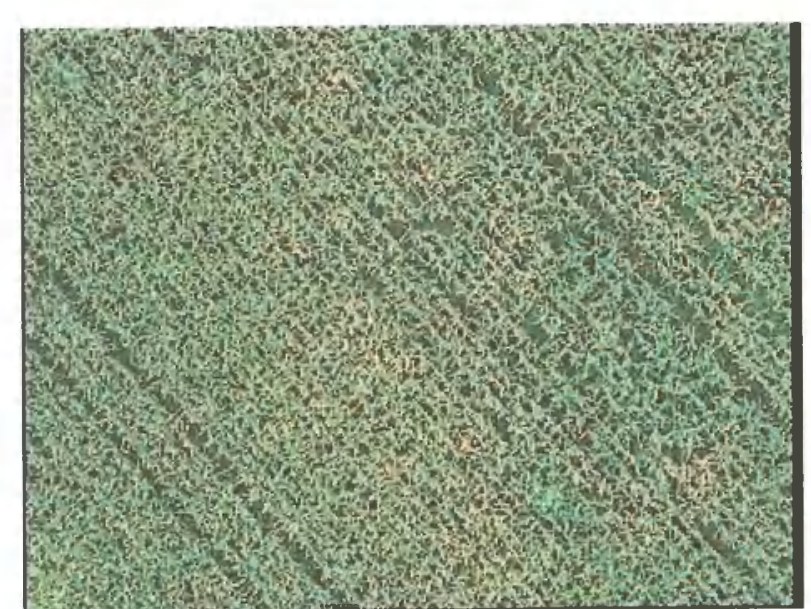

(a)

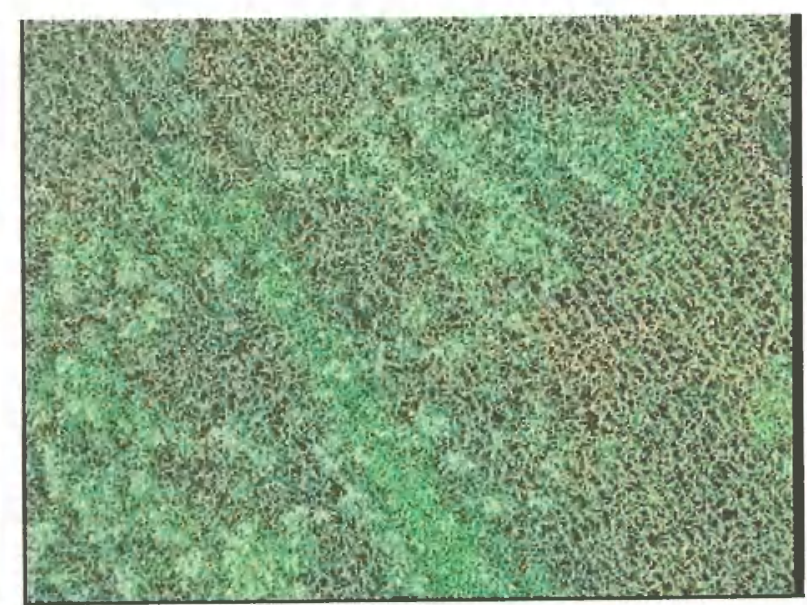

(b)

Figura 7.9: Imagens em grande escala de milho sem (a) e com (b) presença de plantas invasoras. 


\subsubsection{Processamento Computacional das Imagens}

Além da análise visual das imagens, foi tambérn realizada por pesquisadores da Embrapa uma análise computacional das imagens utilizando-se software específico para esta funcionalidade. Foram analisadas apenas as imagens de alta resolução, por apresentarem maior interesse agronômico.

O software de processamento das imagens, baseado no uso de redes neurais artificiais, realizon a segmentação das imagens, possibilitando a quantização das características de interesse da cultura mencionadas na seção 7.6.1. O processamento se torna automático após o treinamento das redes neurais com urn subconjunto das imagens representativo do conjunto completo. As características identificadas e isoladas pela segmentação das imagens foram as seguintes:

- Falhas no plantio;

- Presença de doenças

- Nivel de cobertura do solo.

Exemplos de segmentação das imagens são apresentados nas figuras 7.10, 7.11, 7.12 e 7.13. $\Lambda$ figura 7.10 mostra uma região da cultura de soja infestada por nematóides. Na figura 7.11 é identificada uma falha de plantio na cultura de soja. A figura 7.12 indica a presença de uma região de doença na cultura de milho. A figura 7.13 mostra urna análise da cobertura do solo em uma cultura de algodão. 


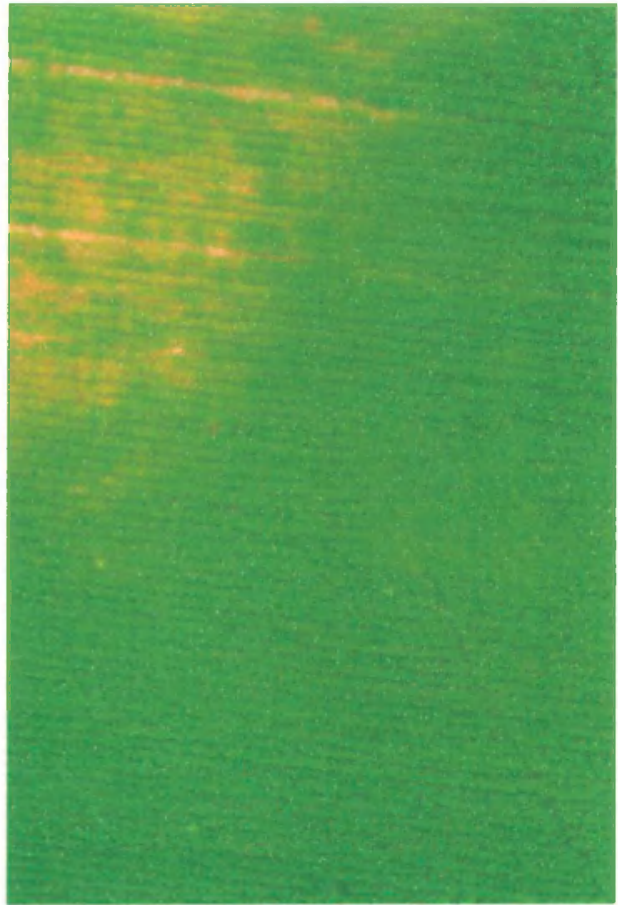

(a)

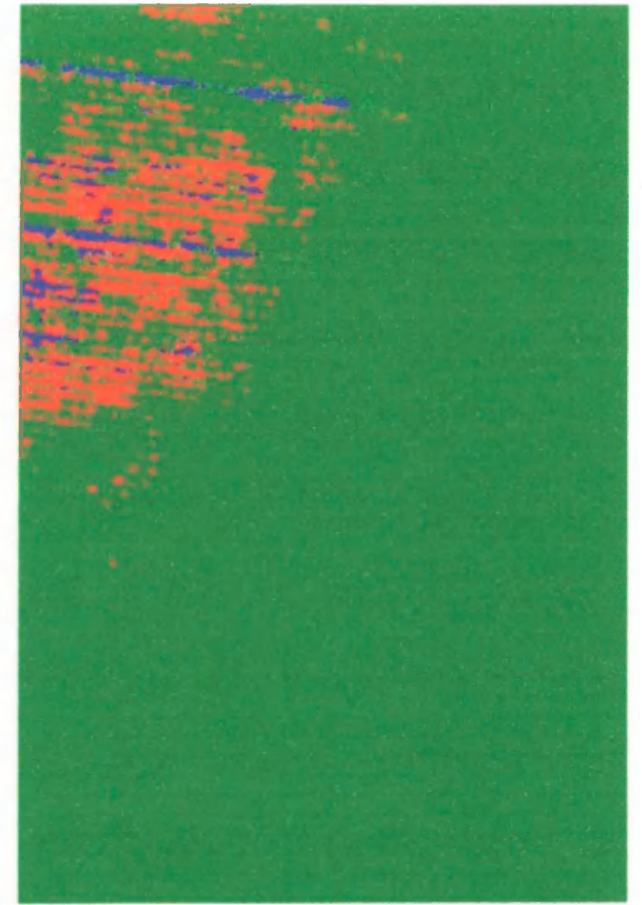

(b)

Figura 7.10: Nematóides em área de soja - imagens original (a) e segmentada (b).

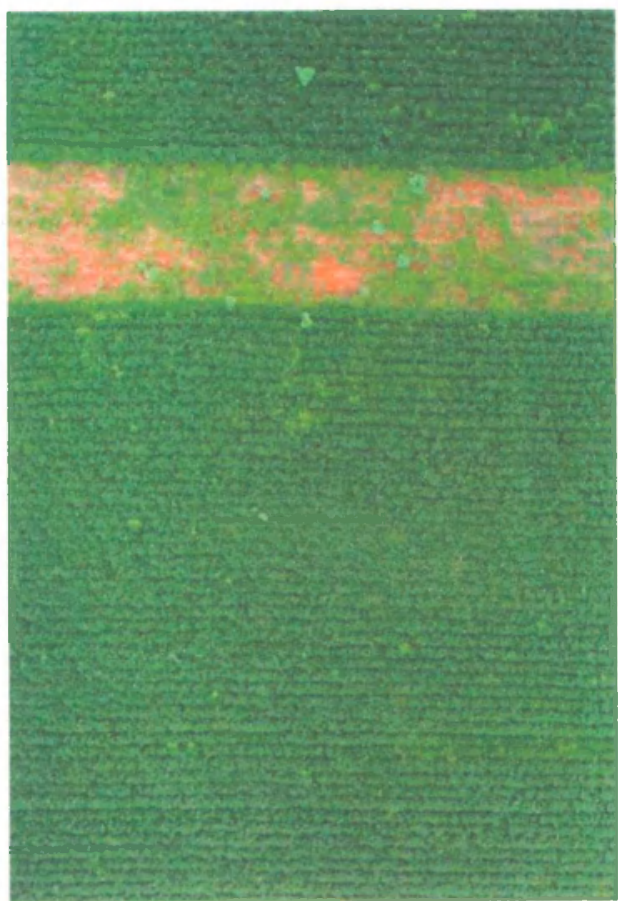

(a)

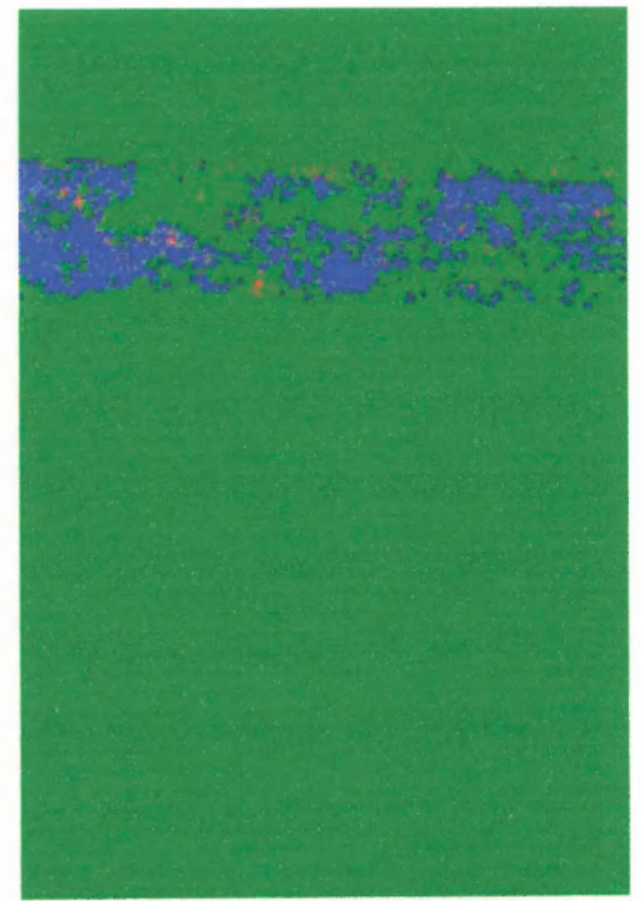

(b)

Figura 7.11: Falha de plantio em área de soja - imagens original (a) e segmentada (b). 


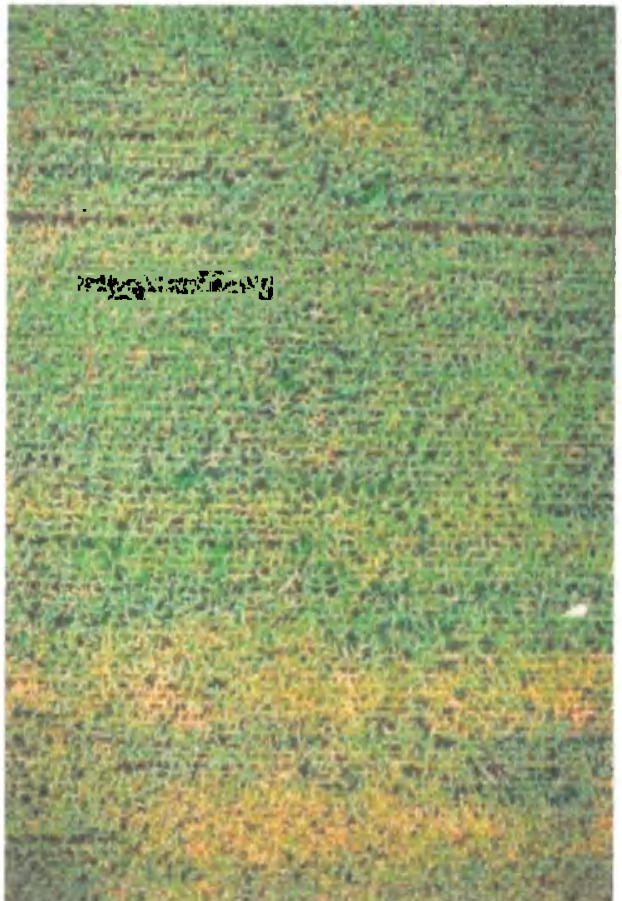

(a)

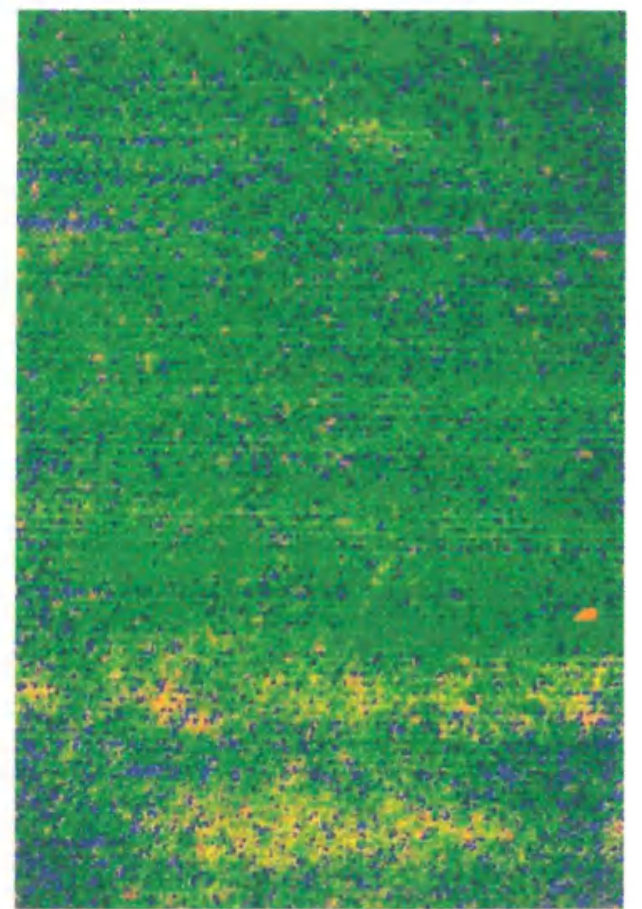

(b)

Figura 7.12: Doença em área de milho - imagens original (a) e segmentada (b).

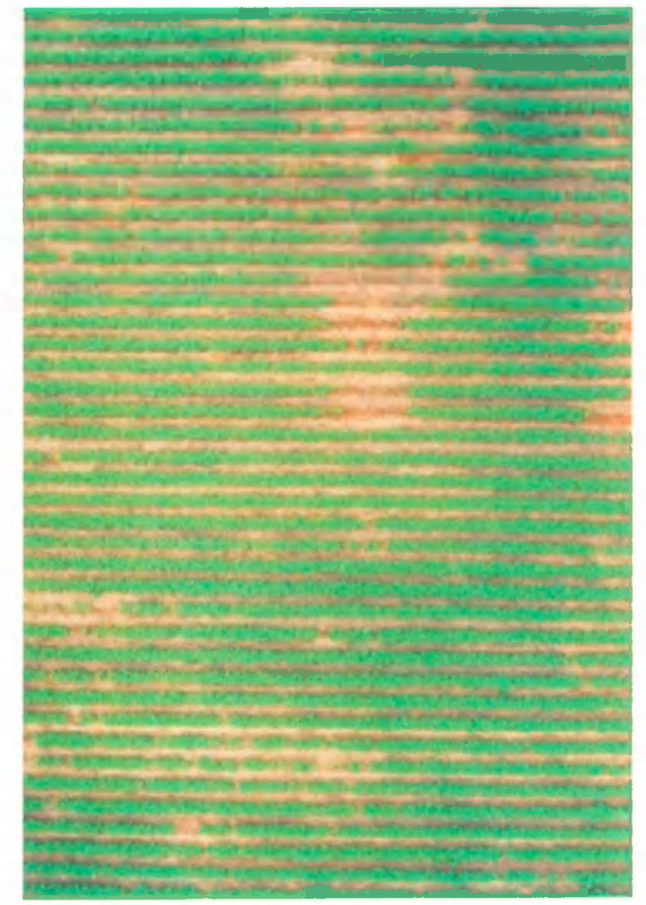

(a)

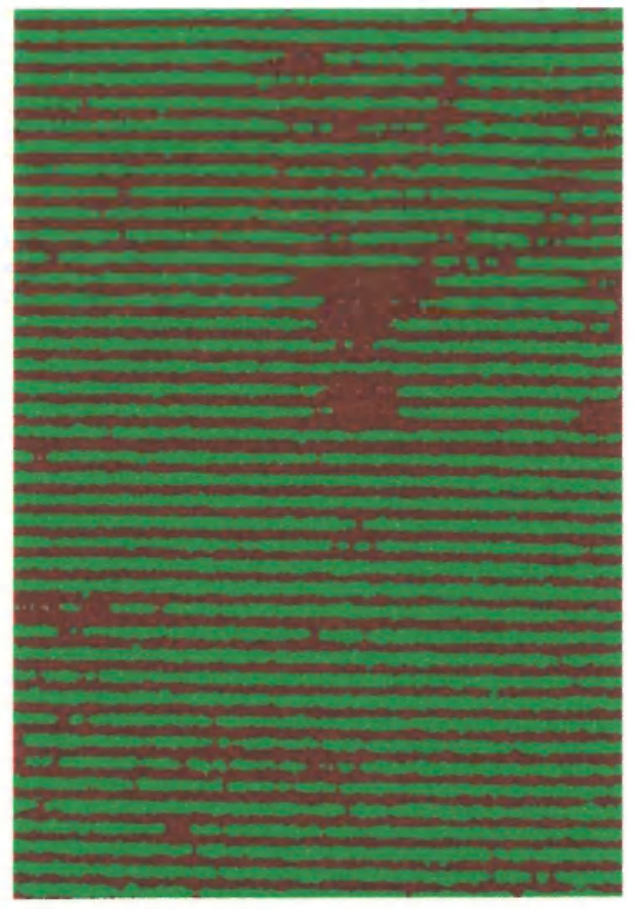

(b)

Figura 7.13: Cobertura de solo em área de algodão - imagens original (a) e segmentada (b). 


\subsubsection{Integração dos Dados em um SIG}

Para que os dados gerados na análise das imagens, seja ela visual ou por software de processamento de imagens, possam ser melhor avaliados, é necessário que sejam introduzidos em um SIG. É possível gerar mapas temáticos das áeras de interesse contendo as grandezas coletadas a partir das imagens, ou mesmo cruzar as informações coletadas.

A partir dos dados coletados na missão realizada com o SciaGeo na Fazenda Campo Bom, foram gerados mapas utilizando o software Maplnfo. O Maplnfo pode ser considerado um SIG simplificado, utilizado para geração e manipulação de mapas e tabelas contendo dados referenciados por coordenadas geográficas.

Na figura 7.14 é apresentado um mapa com as posições das imagens identificadas por pontos e mapeadas por cor. Nesse mapa é indicada a porcentagem de cobertura de solo nas áreas amostradas. Tons vermelhos indicam locais em que a cobertura do solo é baixa, e podem ter ocorrido falhas de plantio ou mau desenvolvimento da cultura.

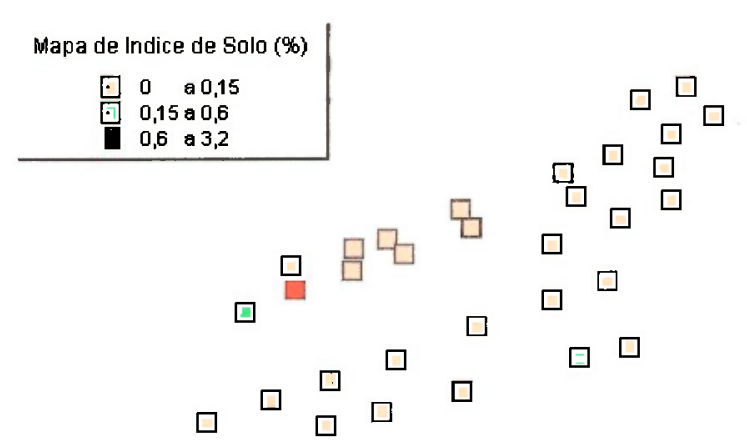

Figura 7.14: Mapa indicando a porcentagem da área contendo solo nu nos pontos de amostragem. 


\subsection{Considerações Finais}

Nesta seção foram apresentados os resultiados obtidos durante uma missão real de utilização do SciaGeo como ferramenta de imageamento aéreo. Os resultados obtidos foram significativos, e pôde ser observada a utilidade real das imagens e dos dados delas extraídos para que o produtor tenha um maior conhecimento sobre as condições reais da cultura.

Durantc a avaliação dos resultados, foi possível notar pontos onde existem dificuldades quanto à manipulaçĩo dos dados gerados. O controle e organização manual de fotografias em filme convencional é uma tarefa trabalhosa e bastante sujeita a falhas. A utilização de uma câmera fotográfica digital pode simplificar muito as tarefas pós-vôo.

A grande quantidade de imagens de baixa resolução geradas pelo SciaGeo também deve ser levada em consideração. É necessário o desenvolvimento de ferramentas específicas para seleção de imagens, pois muitas imagens da filmadora não têm utilidade - durante decolagem e pouso, por exemplo. O tratamento manual de coordenadas e arquivos se torna inviável para um número tão grande de imagens. Por esse mesmo motivo, a validação do processamento digital das imagens de baixa resolução deve ser realizado, pois o elevado número das imagens inviabiliza sua análise visual.

Uma constatação feita a partir da missão realizada foi a viabilidade operacional do equipamento. A instalação do SciaGco na acronave foi bastante simples e a operação do sistema em vôo se mostrou perfeitamente viável.

O resultado mais positivo obtido a partir da missão na Fazenda Campo Bom foi a constatação de que as imagens de alta resolução apresentam condições que permitem seu correto processamento digital. $\Lambda$ segmentação das imagens pelo método de redes neurais desenvolvido pelos colaboradores da Embrapa mostrou resultados positivos, gerando dados importantes agronomicamente.

O próximo capítulo apresenta as principais conclusões resultantes do trabalho, incluindo as dificuldades encontradas durante o desenvolvimento e sugestões de trabalho futuros baseados no SciaGeo. 


\section{Capítulo 8}

\section{Conclusões}

\subsection{Introdução}

O objetivo inicial deste trabalho era desenvolver um sistema de imagemamento aéreo modular, flexivel e principalmente com um baixo custo de aquisição e operação, que viabilizasse a sua utjlização em uma ampla gama de atividades. Com base nos resultados obtidos e apresentados nesta dissertação, pode-se dizer que foi possível atingir esse objetivo. As principais contribuições deste trabalho são citadas na seção 8.2. Algumas dificuldades encontradas no desenvolvimento estão listadas na seção 8.3 .

Apesar dos bons resultados obtidos, o sistema desenvolvido ainda dá espaço a uma série de melhorias. Alguns pontos que podem ser melhorados no SciaGeo são apresentados na seção 8.4, juntamente con sugestões de trabalhos posteriores baseados nos dados de saída do SciaGeo.

\subsection{Contribuições}

Pode-se dizer que a principal contribuição deste trabalho é a disponibilização de um sistema de captura de imagens que pode gerar dados de forma economicamente acessivel e perfeitamente aplicável, conforme visto no capítulo 7. Além disso, este trabalho pode alavancar uma série de trabalhos de processamento de imagens utilizando os dados gerados pelo SciaGeo.

A partir das imagens obtidas, é possível identificar algumas características da cultura de forma abrangente, e que seriam vistas com maior dificuldade em avaliações terrestres. Além disso, sobrevoar uma área agrícola é bem mais rápido do que percorrê-la por via terrestre. Entre as caracteristicas visualizadas nas culturas, pode-se citar:

- Falhas no plantio (áreas de solo nu); 
- Presença de plantas indesejáveis competindo com a cultura (invasoras), com tonalidade de verde diferente;

- Presença de doenças;

- Presença de pragas.

A visualização desses eventos mostra ao produtor que existe margem para um melhor aproveitamento da área cultivada, e o auxilia na decisão sobre como devem ser investidos os seus recursos. A integraçĩo de dispositivos de aplicaçãa de defensivos agrícolas com taxa variada, com base nos dados de saída do SciaGeo, também permitiria uma maior economia na aquisição dos mesmos, evitando desperdícios e aumentando o lucro do produtor.

Particularmente, os trabalhos combinados em processamento de imagens e agricultura do precisão prometem um grande avanço para a agricultura no Brasil, caso as técnicas em desenvolvimento sejam aplicadas efetivamente. O SciaGco contribui para o avanço desses sistemas provendo dados amostrais das culturas agrícolas a um baixo custo, tornando essa tecnologia mais acessível ao produtor comum.

\subsection{Dificuldades Encontradas}

As principais dificuldades encontradas no desenvolvimento deste trabalho foram pontuais, e estão relacionadas principalmente ao processamento dos dados de saída. Mais especificamente, algumas dificuldade cncontradas durante o desenvolvimetno foram:

- Análise de um grande número de imagens sem ferramentas automatizadas;

- Grande força de trabalho utilizada no processamento manual de imagens em filme fotográfico;

- Dificuldade na captura das imagens de forma não-entrelaçada utilizando vídeo digital.

Nenhuma dificuldade técnica que prejudicasse significativarnente o trabalho foi encontrada, tanto em nivel de projeto de software quanto de hardware.

\subsection{Trabalhos Futuros}

As sugestões de trabalhos futuros ligadas mais diretamente ao desenvolvimento do SciaGeo são o planejamento de missões, auxílio à navegação e disparo automático de fotografias 


\subsubsection{Planejamento de Missões}

O plancjamento de missões deve ser feito com a delimitação da área a ser sobrevoada e a definição de alguns parâmetros do vôo, como altitude e configuração das câmeras e lentes. O desenvolvimento de software específico para esse fim permite ao operador do SciaGeo calcular melhor esses parâmetros, a partir das características da cultura e do problema a ser observado. A variação da altitude de vôo e da distância focal das lentes, por cxemplo, altera a resolução final das imagens, que deve ser adequada ao problema que sc deseja visualizar. A definição de pontos de interesse no módulo de planejamento de missões também é um pré-requisito para desenvolver o auxílio à navegação, citado no próximo tópico.

\subsubsection{Auxílio à Navegação}

Como está atualmente, o SciaGeo é depende da habilidade do piloto e/ou co-piloto para a navegação e identificação visual de áreas de interesse a screm imageadas. Sugere-se como trabalho futuro o desenvolvimento de um módulo de software para o palmtop com uma interface gráfica de navegação por GPS.

O módulo de planejamento de missões citado anteriormente permitiria a definição de pontos de intcresse onde devem ser obtidas as imagens. A função principal do módulo de navegação seria a de instruir o piloto sobre como atingir esses pontos de interesse na área imageada. Com a importação dos dados gerados no planejamcnto da missão para o módulo de auxílio à navegação, o piloto teria maior facilidade em cobrir a área monitorada, seguindo o curso indicado no palmtop. A interface de anxílio à navegação pode ser baseada apenas nos dados do receptor GPS, eventualmente utilizando outros sensores, como uma bússola magnética, por exemplo.

\subsubsection{Disparo Automático de Fotografias}

Outra funcionalidade que facilitaria a operação do SciaGeo em vôo é o disparo antomático de fotografias. O próprio software de auxílio à navegação poderia ser desenvolvido de modo a gerar um evento de disparo de fotografia, uma vez atingido o ponto de interesse. Isso eliminaria uma das tarefas a serem realizadas pelo piloto, permitindo que ele concentre sua atenção na navegação da aeronave, tornando a missão mais segura e efetiva.

O diparo automático de fotografias associado a um sensor de atitude garantiria também a obtenção de imagens com menor desvio do eixo vertical. 


\subsubsection{Outros Trabalhos}

Há outras sugestões de trabalhos futuros, porćm não tão relacionadas ao desenvolvimento do SciaGeo como as citadas acima, mas sim ao processamento dos dados de saída do sistema. São elas:

- Processamento das imagens geradas utilizando técnicas variadas de processamento de imagens digitais;

- Validação do processamento digital das imagens de baixa resolução;

- Desenvolvimento de ferramentas automáticas para seleção e processamento de um grande número de imagens de baixa resolução;

- Utilização de uma câmera fotográfica digital juntamente com a avaliação da facilidade de uso;

- Captura e processamento de imagens com o SciaGeo em diversos tipos de cultura agrícola. 


\section{Referências Bibliográficas}

[ABE 02] ABER, J. S.; ABER, S. W. Unmanned small-format aerial photography from kites for acquiring largc-scale, high-resolution, multiview-angle imagery. In: FIEOS 2002 CONFERENCE PROCEEDINGS, 2002. [s.n.], 2002.

[ANG 02] ANGEL, $\Lambda$. et al. Methods of traffic data collection, using aerial video. In: PROC. IEEE 5 TH INTERNATIONAL CONFERENCE ON INTELLIGENT TRANSPORTATION SYSTEMS, 2002. [s.n.], 2002. p.31 36.

[BAR 88] BARTHOLOMé, E.; GREGOIRE, J. M. Small format air photo from ultralight aircraft as an aid for data collection of agricultural statistics in sahelian countries. In: PROCEEDINGS OF IGARSS'88 SYMPOSIUM, 1988. Proceedings... Edinburgh, Scotland:[s.n.], 1988.

[BAR. 93] BARZOHAR, M. Automatic finding of main roads in acrial images by using geometricstochastic models and estimation. In: PROC. GEOSCIENCE COMPUTER VISION AND PATTERN RECOGNITION, 1993. [s.n.], 1993. p.459-464.

[BEC 89] BECKER, U. J. Automatic traffic data collection using aerial video images. In: SECOND INTERNATIONAL CONFERENCE ON ROAD TRAFFIC MONITORING, 1989. [s.n.], 1989. p.79-83.

[BLA 99] BLANC, N. Ced versus cmos - has ced imaging come to an end? In: PHOTOGRAMMETRIC WEEK 1999, 1999. Proceedings... Institute for Photogrammetry, University of Stuttgart, Germany:[s.n.], 1999. p.131-137.

[BUR 98] BURMAN, H. Image orientation by gps and ins. In: INTERNATIONAL ARCHIVES of PHotogrammetry AND Remote SENSING, 1998. Proceedings... Ohio, US:[S.I.], 1998. v.32. 
[CAM 96] CAMARA, G. ct al. Anatomia de Sistemas de Informação Geográfica. Unicamp, 1996.

[CRA 99] CRAMER, M. Direct geocoding - is aerial triangulation obsolete? In: PHOTOGRAMMETRIC WEEK 1999, 1999. Proceedings... Institute for Photogrammetry, University of Stultgart, Germany:[s.n.], 1999. p.59 70 .

[CRA 00] CRAMER, M.; STALLMANN, D. Direct georelerencing using gps/inertial exterior orientations for photogrammetric applications. International Archives on Photogrammetry and Remote Sensing, [S.l.], v.XXXIII, p.198-206, 2000.

[CRA 01] CRAMER, M. On the use of direct georeferencing in airborne photogrammetry. In: PROCEEDINGS 3RD. IN'TERNATIONAL SYMPOSIUM ON MOBILE MAPPING TECHNOLOGY, 2001. Proceedings... Cairo:[s.n.], 2001.

[CUR 03] CURTIN, D. P. Digital Photography $\quad$ - The Textbook. http://www.photocoursc.com, 2003.

[FRè 98] FRèRE, D. et al. Automatic modelling and 3d reconstruction of urban buildings from aerial imagery. In: GEOSCIENCE AND REMOTE SENSING SYMPOSIUM PROCEEDINGS. IGARSS'98, 1998. [s.n.], 1998. v.5, p.2593-2596.

[GRA 86] GRAHAM, R. Manual of Aerial Photography. Focal Press, 1986.

[HAR 03] HARRIS, T. How Camcorders Work. http://www.howstuffworks.com/camcorder.htm, 2003.

[HED 79] HEDGECOE, J. Introductory Photograpyh Course. Mitchell Beazley, 1979.

[JAC 88] JACOBSON, R. E.; RAY, S. F. The Manual of Photography. Focal Press, 2. ed., 1988.

[JOH 96] JOHNSON, E. N. et al. The 1996 mit/boston university/draper laboratory autonomous helicopter system. In: PIROCEEDINGS OF THE DIGITAL AVIONICS SYSTEMS CONFERENCE - 15TH AIAA/IEEE, 1996. [s.n.], 1996. p.381-386.

[KAP 96] KAPLAN, E. D. Understanding GPS - Principles and Applications. Artech House Publishers, 1996.

[LAN 78] LANGFord, M. The Step by Step Guide to Photography - A Complete Manual. Ebury Press, 1978. 
[LAU 92] LAURINI, R. Fundamentals of Spatial Information Systems. Academic Press, 1992.

[LIT 01] LITWILLER, D. Ccd vs. cmos: Facts and fiction. Photonics Spectra, [S.I.], January 2001.

[LOG 92] LOGSDON, T. The Navstar Global Positioning System. Van Nostrand Reinhold, 1992.

[MAG 91] MAGUIRE, D. J.; GOODCHILD, M. F. Geographical Information Systems, v.1. Longman Scientific and Technical, 1991.

[MAR. 90] MARChETTl, D. A. B. Princípios de Fotogrametria e Fotointerpretação. Nobel, 1990.

[MON 00] MONICO, J. F. G. Posicionamento pelo Navstar-GPS. Editora Unesp, 2000.

[MOR 01] MOREIRA, M. A. Fundamentos do Sensoriamento Remoto. Instituto Nacional de Pesquisas Espaciais (INPE), 2001.

[NET 96] NETANYAHU, N. S. et al. Robust detection of road segments in noisy aerial images. In: PROCEEDINGS OF THE 13TH INTERNATIONAL CONFERENCE ON PATTERN RECOGNITION, 1996. [s.n.], 1996. v.2, p.151-155.

[NIC 03] NICE, K. How Digital Cameras Work. http://electronics.howstuffworks.com/digital-camera.htm, 2003.

[PAR 86] PAREDES, E. A. Introdução à Aerofotogrametria para Engenheiros, v.1. CNPq: Concitec, 1986.

[RIC 01] RICHETTI, E. Remotely sensed and geophysical data for nondestructive archaeological prospection. In: IEEE 2001 INTERNATIONAL GEOSCIENCE AND REMOTE SENSING SYMPOSIUM. IGARSS'01, 2001. [s.n.], 2001. v.7, p.3084-3086.

[SKA 93] SKALOUD, J. Direct georeferencing in aerial photogrammetric mapping. Photogrammetric Engineering and Remote Sensing: Journal of the American Society for Photogrammetry and Remote Sensing, [S.I.], v.68, n.3, p.207-210, March, 1993. 
[TOR 00] TORRE, M. Agricultural-ficld extraction on acrial images by region competition algorithm. In: PROC. 15TH INTERNATIONAL CONFERENCE ON PATTERN RECOGNITION, 2000. [s.n.], 2000. v.1, p.313-316.

[Tri 00] Trindade Jr., O.; CARMO, M. S. Small aircraft for application in agriculture. In: PROCEEDINGS OF THE 2000 ASAE ANNUAL INTERNATIONAL MEETING, 2000. Proceedings... Milwaukee, USA:[s.n.], 2000.

[VAN 98] VANDEKERCKHOVE, J. et al. Semi-automatic modelling of urban buildings from high resolution aerial imagery. In: PROC. COMPUTER GRAPHICS INTERNATIONAL, 1998, 1998. [s.n.], 1998. p.588-596.

[WAR 96] WARNER, W. S.; GRAHAM, R. W. Small Format Aerial Photography. Whittles Publishing, 1996. 


\section{Apêndice A}

\section{Diagramas Esquemáticos}

Neste apêndice são apresentados os diagramas esquemáticos dos módulos de hardware utilizados pelo SciaGeo. A figura A.1 apresenta o diagrama do conversor de níveis lógicos RS232/TTL. Na figura A.2 é mostrado o esquema da fonte chaveada utilizada pelo sistema. O modem de $2400 \mathrm{bps}$ utilizado para modulação e demodulação dos sinais digitais no canal de áudio da filmadora é apresentado na figura A.3. Finalmente, a placa controladora de câmera tẹn o esquema apresentado na figura A.4.
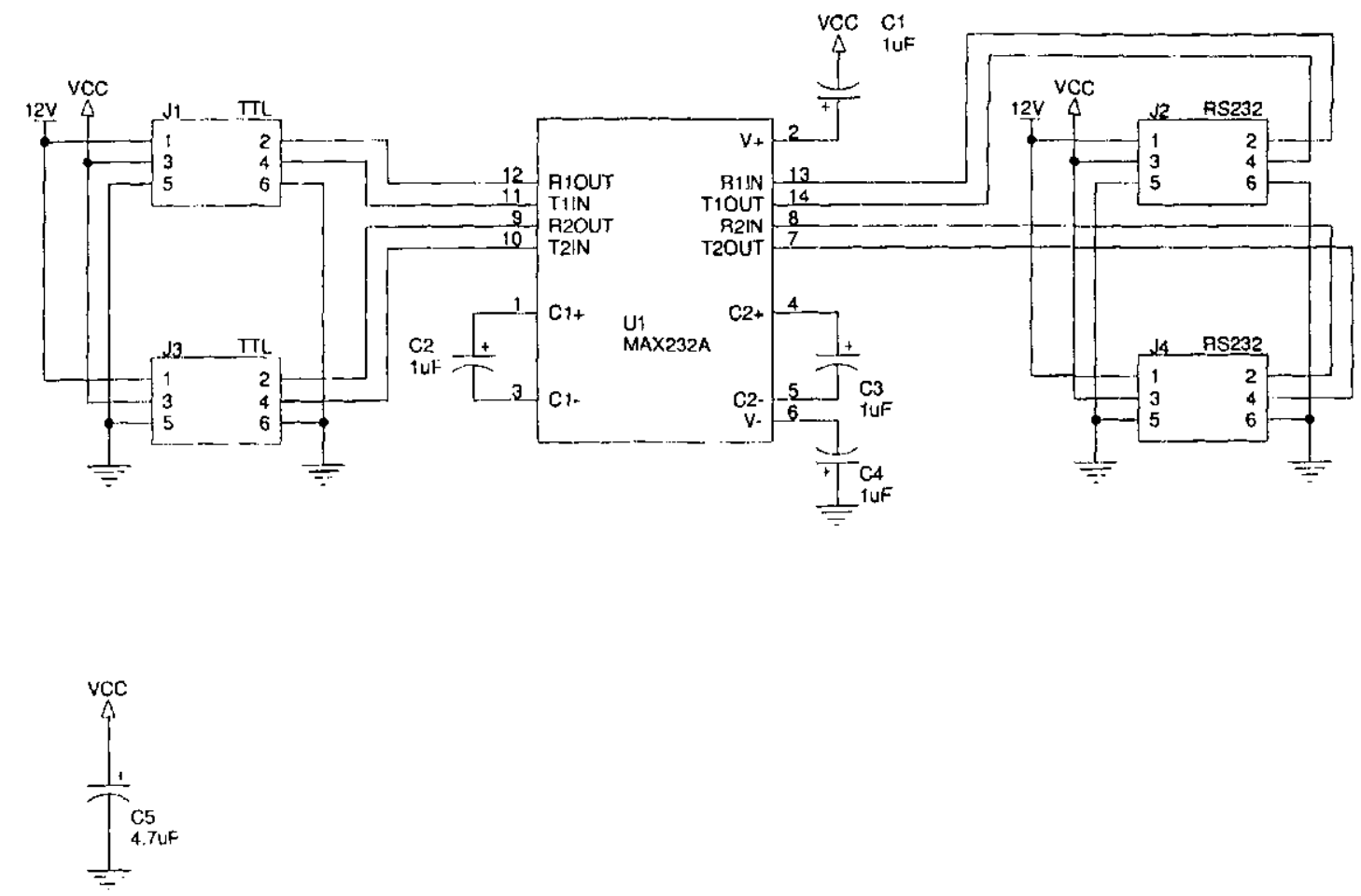

Figura A.1: Diugrama esquemático da placa do conversor de níveis lógicos RS232/TTL. 


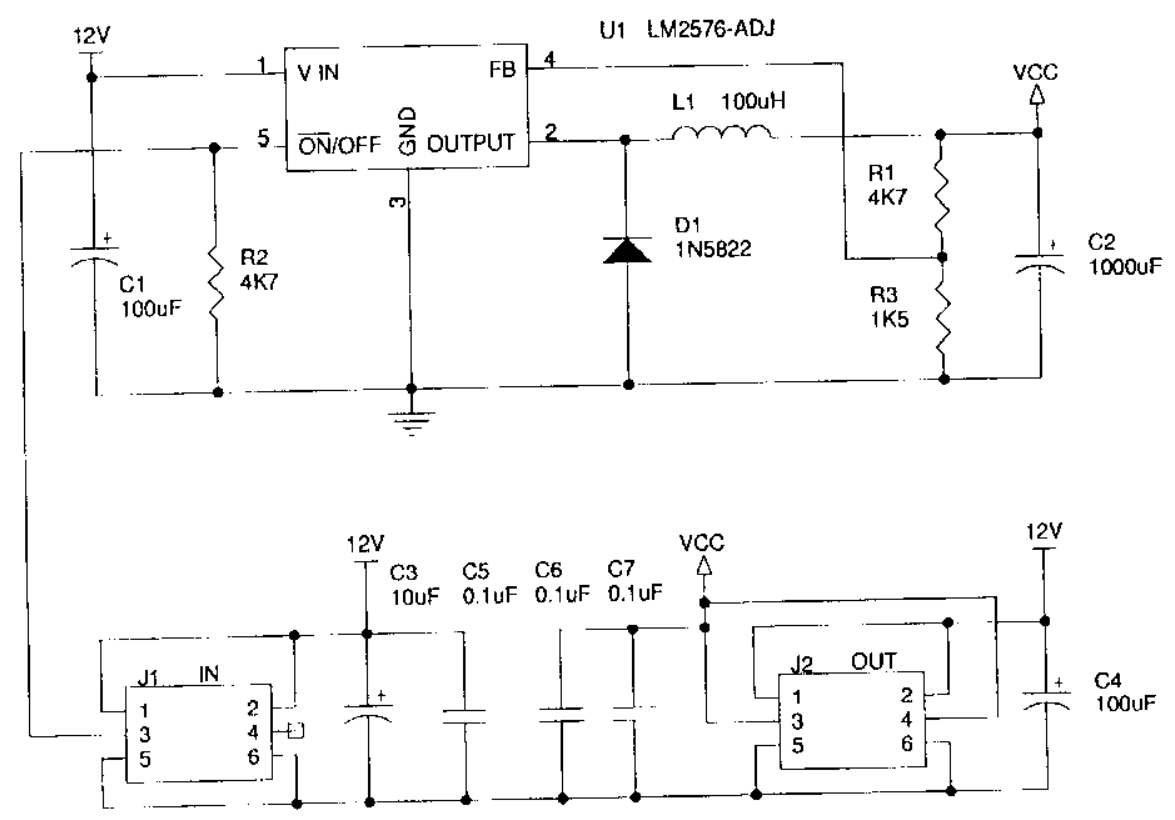

Figura 4.2: Diagrama esquemático da fonte de alimentação chaveada utilizada pelo SciaGeo.

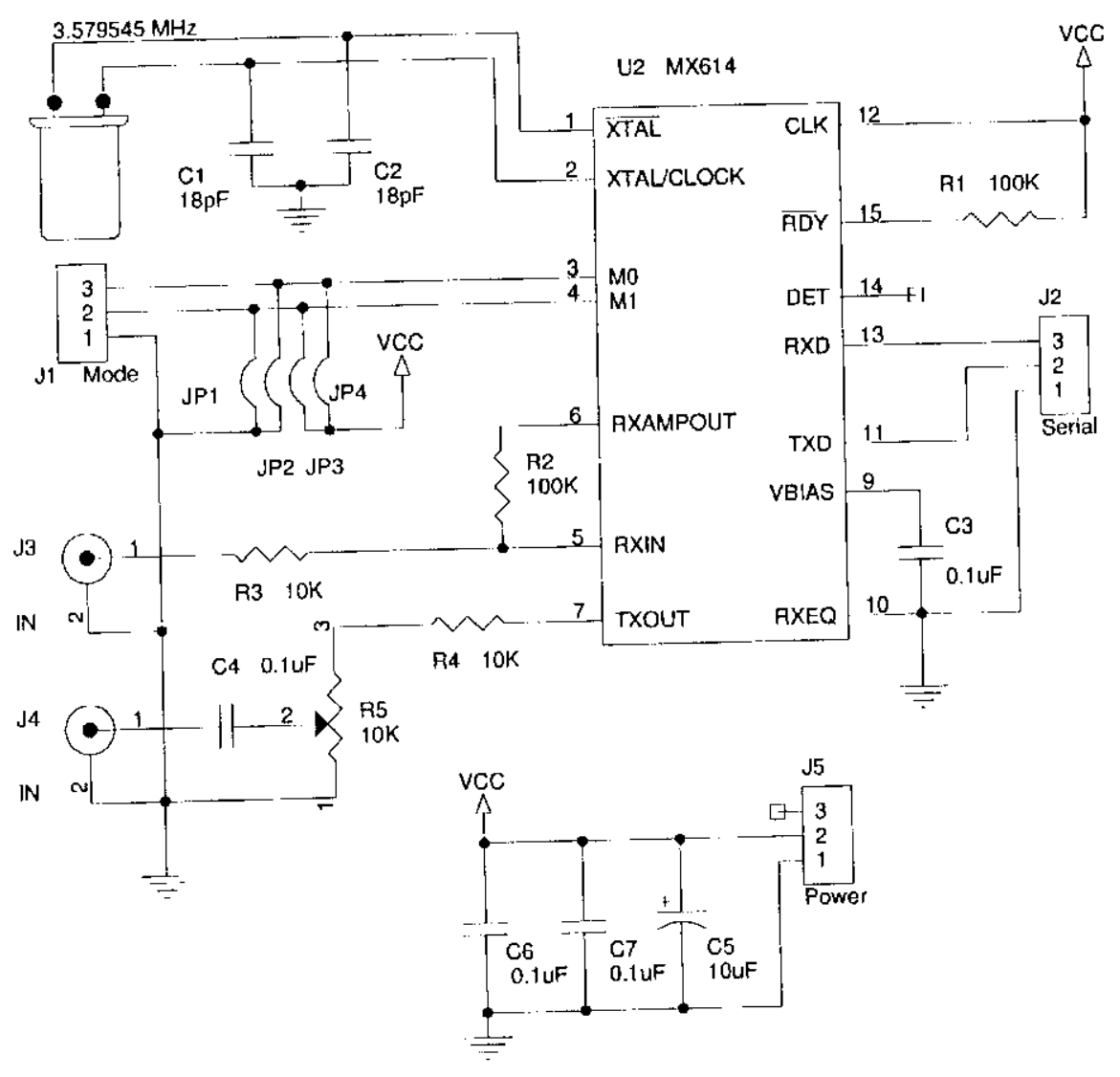

Figura A.3: Diagrama esquemático do modem de 2400bps utilizado para modulação e demodulação dos sinais digitais no canal de áudio da filmadora. 


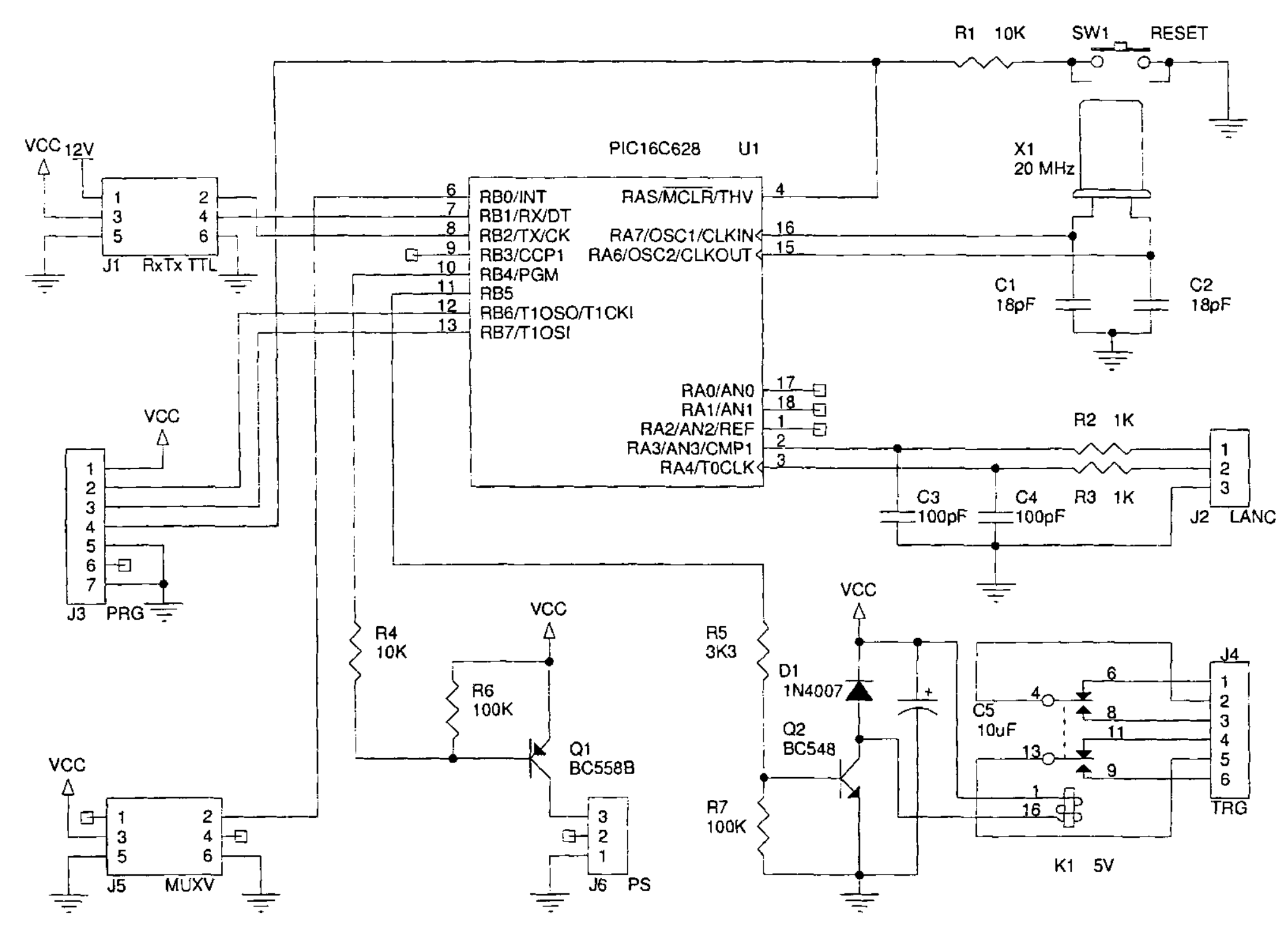

Figura A.4: Diagrama esquemático da placa controladora de câmera. 


\section{Apêndice B}

\section{Protocolos de Comunicação}

Neste apêndice são apresentados os protocolos de software especificados e implementados para o SicaGeo. Todos os protocolos utilizam a técnica de character stuffing na seção de dados do pacote (entre os pares DLE/STX e DLE/ETX). Todos os pacotes seguem o seguinte modelo:

\begin{tabular}{|l|l|l|}
\hline Bytes & Tipo & Descrição \\
\hline 1 & byte & DLE \\
1 & byte & STX \\
$\mathrm{N}$ & & Seção de dados \\
1 & byte & CRC16 byte 1 \\
1 & byte & CRC16 byte 2 \\
1 & byte & DLE \\
1 & byte & ETX \\
\hline
\end{tabular}

O código de verificaçäo de erro CRC16 é calculado sobre aseção de dados do pacote. A seguir são especificadas as seções de dados de cada pacote em particular.

\section{B.1 Pacote de Dados de Posicionamento}

Este pacote é utilizado para envio de dados de posicionamento pelo processador principal. O pacote aqui definido é enviado tanto para o palmtop quanto para a trilha de áudio da filmadora. 


\begin{tabular}{|l|l|l|}
\hline Bytes & Tipo & Descrição \\
\hline \hline 2 & unsigned int & Velocidade (km/h) \\
2 & int & Latitude (graus) \\
4 & float & Latitude (minutos) \\
2 & int & Longitude (graus) \\
4 & float & Longitude (minutos) \\
2 & int & Altitudo em relação ao nivel do mar (metros) \\
4 & float & PDOP \\
4 & float & HDOP \\
4 & float & VDOP \\
1 & byte & Número de satélites em vista \\
1 & byte & Númcro de satélitcs cm uso \\
1 & byte & Data (dia) \\
1 & byte & Data (mês) \\
1 & byte & Data (ano) \\
1 & byte & Hora (horas) \\
1 & byte & Hora (minutos) \\
1 & byte & Hora (segundos) \\
\hline
\end{tabular}

\section{B.1.1 Pacote de Disparo de Fotografia}

Este pacote ć enviado do palmtop para o processador principal e deste último para o controlador de câmera.

\begin{tabular}{|l|l|l|}
\hline Byles & T'ipo & Descrição \\
\hline \hline 1 & byte & $0 \times 00$ \\
1 & bytc & $0 \times 00$ \\
\hline
\end{tabular}

\section{B.1.2 Pacote de Controle da Filmadora}

Este pacote é enviado do palmtop para o processador principal e deste últino para o controlador de câmera. 


\begin{tabular}{|l|l|l|}
\hline Bytes & Tipo & Descrição \\
\hline \hline 1 & byte & $0 \times 00$ \\
1 & byte & $0 \times 01$ \\
1 & byte & Comando LANC byte 1 \\
1 & byte & Comando LANC byte 2 \\
\hline
\end{tabular}

\section{B.1.3 Pacote de Confirmação de Disparo de Fotografia}

Este pacote é enviado do controlador de câmera para o processador principal e do processador principal para o palmtop.

\begin{tabular}{|l|l|l|}
\hline Bytes & Tipo & Descrição \\
\hline \hline 1 & byte & $0 \times 01$ \\
1 & byte & $0 \times 00$ \\
\hline
\end{tabular}

\section{B.1.4 Pacote de Confirmação de Controle da Filmadora}

Este pacote é enviado do controlador de câmera para o processador principal e do processador principal para o palmtop.

\begin{tabular}{|l|l|l|}
\hline Bytes & Tipo & Descrição \\
\hline \hline 1 & byte & $0 \times 01$ \\
1 & byte & $0 \times 01$ \\
\hline
\end{tabular}




\section{Apêndice $\mathrm{C}$}

\section{Formato do Arquivo de Coordenadas}

O SciaGeo gera como saída, além das imagens, um arquivo contendo os dados de posicionamento (coordenadas) das mesmas. O arquivo é gravado em texto padrão ASCII, com cada linha de texto contendo uma conjunto de dados de posicionamento de uma imagem. Os campos são delimitados por espaços em branco, e aparecem na seguinte ordem: índice da imagem, latitude (graus), latitude (minutos), latitude (norte/sul), longitude (graus), longitude (minutos), longitude (leste/oeste), altilude em metros, velocidade em $\mathrm{km} / \mathrm{h}$, PDOP, HDOP, VDOP, número de satélites em vista, número de satélites em uso, data (dd/mm/aa), hora (hh:mm:ss).

Um trecho de um arquivo de coordenadas é apresentado, como exemplo, abaixo:

$0001844,183100 \mathrm{~S} 5236,619100$ W $873791,500 \quad 0,8001,3001110$ 24/01/04 18:47:57 0011844,183100 S 5236,619100 W 87379 1,500 0,800 1,300 1110 24/01/04 18:47:57 $0021844,189900 \mathrm{~S} 5236,629700$ W 87379 1,600 $0,800 \quad 1,30011 \quad 10$ 24/01/04 18:47:58 0031844,189900 S 5236,629700 W 87379 1,600 0,800 1,300 1110 24/01/04 18:47:58 0041844,206600 S 5236,648700 W 87481 1,600 0,800 1,300 1110 24/01/04 18:48:00 $0051844,206600 \mathrm{~S} 5236,648700$ W 87481 1,600 0,800 1,300 1110 24/01/04 18:48:00 0061844,206600 S 5236,648700 W $87481 \quad 1,600 \quad 0,800 \quad 1,3001110$ 24/01/04 18:48:00 0071844,215900 S 5236,657300 W 87681 1,600 0,900 1,400 1110 24/01/04 18:48:01 0081844,215900 S 5236,657300 W 87681 1,600 0,900 1,400 1110 24/01/04 18:48:01 $0091844,225800 \mathrm{~S} 5236,665200$ W $878811,500 \quad 0,8001,3001110$ 24/01/04 18:48:02 0101844,225800 S 5236,665200 W $87881 \quad 1,500 \quad 0,800 \quad 1,3001110$ 24/01/04 18:48:02 $0111844,236300 \mathrm{~S} 5236,672100 \mathrm{~W} 87981$ 1,600 0,800 1,400 1110 24/01/04 18:48:03 0121844,236300 S 5236,672100 W 87981 1,600 0,800 1,400 1110 24/01/04 18:48:03 $0131844,236300 \mathrm{~S} 52 \quad 36,672100$ W $87981 \quad 1,600 \quad 0,8001,40011 \quad 10 \quad 24 / 01 / 04 \quad 18: 48: 03$ 